

\section{Verkennende studie naar hittestress bij melkvee tijdens weidegang in gematigde klimaatstreken}

M. Timmerman, K. van Reenen, H. Holster, A. Evers

Dit onderzoek is uitgevoerd door Wageningen Livestock Research en gefinancierd door het Melkveefonds.

Wageningen Livestock Research

Wageningen, September 2018

Rapport 1117 
Timmerman, M., K. van Reenen, H. Holster, A. Evers, 2018. Verkennende studie naar hittestress bij melkvee tijdens weidegang in gematigde klimaatstreken. Wageningen Livestock Research, Rapport 1117.

Samenvatting NL Er is een verkennende studie uitgevoerd om inzicht verkrijgen in de effecten van hittestress tijdens weidegang op de melkproductie, gezondheid en welzijn van melkkoeien en de economische gevolgen daarvan onder Nederlandse klimaatomstandigheden. Tevens is een verkenning uitgevoerd naar opties om de effecten van hittestress tijdens weidegang te reduceren. In deze rapportage zijn de resultaten van deze studie beschreven.

Summary UK An exploratory study has been conducted to gain insight into the effects of heat stress during grazing on milk production, health and welfare of dairy cows, and the economic consequences of this under Dutch climate conditions. Furthermore an exploration was carried out into options to reduce the effects of heat stress during grazing. The results of this study are described in this report.

Dit rapport is gratis te downloaden op https://doi.org/10.18174/460412 of op www.wur.nl/livestock-research (onder Wageningen Livestock Research publicaties).

\section{(C) 2018 Wageningen Livestock Research}

Postbus 338, 6700 AH Wageningen, T 03174839 53, E info.livestockresearch@wur.nl, www.wur.nl/livestock-research. Wageningen Livestock Research is onderdeel van Wageningen University \& Research.

Wageningen Livestock Research aanvaardt geen aansprakelijkheid voor eventuele schade voortvloeiend uit het gebruik van de resultaten van dit onderzoek of de toepassing van de adviezen.

Alle rechten voorbehouden. Niets uit deze uitgave mag worden vermenigvuldigd en/of openbaar gemaakt worden door middel van druk, fotokopie, microfilm of op welke wijze dan ook zonder voorafgaande toestemming van de uitgever of auteur.

Wageningen Livestock Research is NEN-EN-ISO 9001:2015 gecertificeerd.

Op al onze onderzoeksopdrachten zijn de Algemene Voorwaarden van de Animal Sciences Group van toepassing. Deze zijn gedeponeerd bij de Arrondissementsrechtbank Zwolle. 


\section{Inhoud}

$\begin{array}{ll}\text { Samenvatting } & 5\end{array}$

1

$\begin{array}{ll}\text { Inleiding } & 11\end{array}$

1.1 Aanleiding 11

1.2 Doel 11

$\begin{array}{lll}1.3 & \text { Afbakening } & 12\end{array}$

Hittestress bij melkvee in gematigde klimaten $\quad 13$

2.1 Hittestress indicatoren 13

$\begin{array}{lll}2.2 & \text { Effect op melkproductie en uiergezondheid } & 15\end{array}$

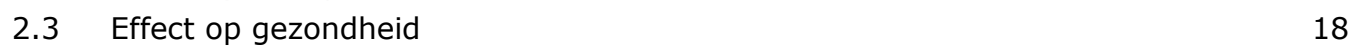

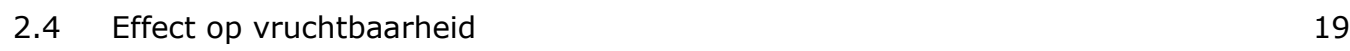

$\begin{array}{ll}2.5 & \text { Effect op gedrag }\end{array}$

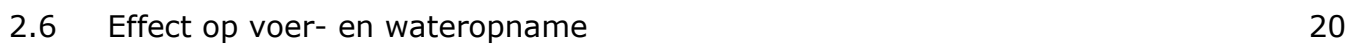

$\begin{array}{lll}2.7 & \text { Effect van schaduwverstrekking } & 21\end{array}$

$\begin{array}{lll}2.8 & \text { Monitoring tools } & 24\end{array}$

$\begin{array}{llr}3 & \text { Klimat in Nederland } & 26\end{array}$

3.1 Huidig klimaat in Nederland $\quad 26$

$\begin{array}{lll}3.2 & \text { Klimaatverandering in Nederland } & 28\end{array}$

4 Economische gevolgen van hittestress bij melkvee 30

4.1 Schatting van de economische effecten 30

$\begin{array}{lll}4.2 & \text { Bedrijfsscenario's } & 31\end{array}$

$5 \quad$ Verkenning van opties om hittestress bij weidegang te reduceren 33

$5.1 \quad$ Weide- en veemanagement 33

$\begin{array}{lll}5.2 & \text { Voeding en water } & 35\end{array}$

$\begin{array}{lll}5.3 & \text { Fokkerij } & 36\end{array}$

$\begin{array}{lll}5.4 & \text { Kunstmatige schaduw en koeling in de wei } & 37\end{array}$

5.5 Biodiversiteit, beplanting en inrichting landschap $\quad 39$

5.6 Voorkomen van (lokale) klimaatverandering 41

$6 \quad$ Kennishiaten $\quad 42$

$\begin{array}{llr}7 & \text { Discussie } & 44\end{array}$

$8 \quad$ Conclusies en aanbevelingen $\quad 46$

$\begin{array}{lll}8.1 & \text { Conclusies } & 46\end{array}$

$\begin{array}{ll}8.2 & \text { Aanbevelingen }\end{array}$

$\begin{array}{ll}\text { Literatuur } & 48\end{array}$

Bijlage 1 Klimaatgegevens per maand $\quad 52$ 



\section{Samenvatting}

Het klimaat in Nederland verandert. De gemiddelde temperatuur in De Bilt nam tussen 1981 en 2010 toe van $16,1^{\circ} \mathrm{C}$ naar $17,0^{\circ} \mathrm{C}$. Het aantal zomerse dagen $\left(\mathrm{T}>25^{\circ} \mathrm{C}\right.$ ) nam toe van 13 naar 21 en de gemiddelde zonne-instraling van 149 naar $153 \mathrm{~kJ} / \mathrm{cm}^{2}$. Modelberekeningen laten voor 2030 een verdere toename van de gemiddelde temperatuur naar $17,9^{\circ} \mathrm{C}$ zien en voor de zonne-instraling naar $156 \mathrm{~kJ} / \mathrm{cm}^{2}$. In de Bilt zijn er gemiddeld 85 warme dagen waarbij de temperatuur boven de $20^{\circ} \mathrm{C}$ uitkomt. Er is sprake van hittestress wanneer er een onbalans is tussen de warmteproductie in de koe en de mogelijkheid om deze warmte kwijt te raken aan de omgeving. Dit gebeurt zodra de bovenste kritische temperatuur van de thermoneutrale zone wordt overschreden, welke tussen de $20-24^{\circ} \mathrm{C}$ ligt voor Holstein koeien. Dit betekent dat op bijna een kwart van de dagen in het jaar in Nederland kans bestaat op hittestress. Als hittestress indicator wordt echter meestal de Temperatuur Luchtvochtigheid Index (THI) gebruikt. Het voordeel van deze indicator is deze gemakkelijk gemeten kan worden doordat alleen de temperatuur en relatieve luchtvochtigheid nodig zijn. Echter zonne-instraling en windsnelheid worden in deze index niet meegenomen, maar zijn ook van invloed op de hittestress die een koe ervaart. Oplopende temperaturen en toenemende zonnestraling zullen ervoor zorgen dat hittestress onder melkkoeien in Nederland vaker zal voorkomen. Met een veranderend en warmer wordend klimaat hebben alle melkkoeien en jongvee (weidend of niet weidend) te maken. Hittestress is daarom in het algemeen een aandachtspunt in de melkveehouderij in Nederland. Om hittestress in de stalomgeving te beperken zijn al verschillende opties beschikbaar zoals ventilatoren, dakisolatie en waterverneveling (Versteeg, 2016). Men kan ervoor kiezen om tijdens zomerse $\left(T>25^{\circ} \mathrm{C}\right)$ en tropische dagen $\left(\mathrm{T}>30^{\circ} \mathrm{C}\right)$ de koeien overdag binnen te houden om zo het effect van de zonne-instraling te verminderen, en 's avonds en 's nachts te weiden omdat het in de wei dan koeler is dan in de stal. Echter de Nederlandse Zuivelketen zet zich in voor het behoud van weidegang en werkt juist aan het verhogen van het percentage weidegang. Oplossingen die hittestress voorkomen of beperken tijdens weidegang dragen daarom bij aan het vergroten van het aantal weide uren per jaar, met meer vers gras in het rantsoen en een lagere ammoniakemissie per koe. Daarom is deze studie is specifiek gericht op het effect van hittestress bij weidegang en oplossingsrichtingen hiervoor.

Het doel van deze verkennende studie was inzicht verkrijgen in de effecten van hittestress tijdens weidegang op de melkproductie, gezondheid en welzijn van melkkoeien, en de economische gevolgen daarvan onder Nederlandse omstandigheden. Verder is een verkenning uitgevoerd naar opties om de effecten van hittestress tijdens weidegang te reduceren.

Via een literatuuronderzoek is onderzocht wat bekend is over de effecten van hittestress op de melkproductie, gezondheid en welzijn bij melkvee in gematigde klimaatstreken die ongeveer vergelijkbare klimaatomstandigheden kennen als in Nederland. Er is specifiek gezocht op artikelen die gingen over hittestress bij melkvee bij weidegang, grazen of gematigde klimaatstreken. Er is geen strikt onderscheid gemaakt tussen weidende en niet-weidende bedrijven, aangezien het bij de verwerking van de literatuurresultaten niet altijd mogelijk was om zo'n strikte scheiding te hanteren. Bij de resultaten van het literatuuronderzoek zitten daardoor ook resultaten van onderzoeken in gematigde klimaatstreken waarbij de koeien jaarrond op stal stonden. Verder zijn onderzoeksresultaten uit (sub)tropische klimaatstreken niet meegenomen in deze studie. Het klimaat in (sub)tropische klimaatstreken kent veel langere periodes met hoge temperaturen $\left(\mathrm{T}>30^{\circ} \mathrm{C}\right)$, hoge nachttemperaturen $\left(T>20^{\circ} \mathrm{C}\right)$ en lage luchtvochtigheid die sterk verschillen van het klimaat in Nederland. Verder speelt mee dat de bedrijfsopzet in (sub)tropische klimaten sterk afwijkt van de bedrijfsopzet in Nederland voor wat betreft rantsoensamenstelling en weidegang.

Uit het uitgevoerde literatuuronderzoek naar de effecten van hittestress op de melkproductie, gezondheid en welzijn bij melkvee in gematigde klimaatstreken zijn de volgende resultaten naar voorgekomen: 


\section{Hittestress indicatoren}

- De Temperatuur Luchtvochtigheid Index (THI), gebaseerd temperatuur en luchtvochtigheid, is de meest gebruikte hittestress indicator. Het voordeel van de THI is dat deze makkelijk is te meten, maar de nadelen zijn dat de zonne-instraling en windsnelheid ontbreken in deze indicator en dat er verschillende formules zijn om de THI te berekenen.

- $\mathrm{Er}$ is geen eenduidige beeld over vanaf welke drempelwaarde negatieve effecten optreden. Negatieve effecten beginnen over het algemeen op te treden tussen een THI van 60 à 70 .

\section{Melkproductie}

- Hittestress zorgt voor een daling in melkproductie, waarbij dalingen tot $-12 \%$ zijn gerapporteerd. Hoe hoger de THI, des te groter de daling in melkproductie was.

- Er blijkt een bedrijfseffect te zijn.

- De daling in melkproductie is het grootst bij melkkoeien met de hoogste dagelijkse melkproductie en het laagst voor koeien met de laagste dagproductie.

- Melkvaarzen blijken minder gevoelig te zijn dan $2^{\mathrm{e}}$ of $3^{\mathrm{e}}$ kalfskoeien.

- Jersey koeien vertoonden een minder grote daling dan Holstein koeien, maar daarentegen was de melkproductie van Jersey koeien ook lager.

\section{Melksamenstelling}

- Hittestress heeft een negatief effect op het vet- en eiwitgehalte in de melk, waarbij dalingen tot $16 \%$ en $-17 \%$ respectievelijk zijn vastgesteld. Hoe hoger de THI, des te groter de daling in gehalten was.

- Jersey koeien vertoonden een minder grote daling in gehalten dan Holstein koeien.

- In één studie zijn negatieve effecten op het caseïne-gehalte vastgesteld.

\section{Celgetal}

- Tijdens warme perioden is het tankmelkcelgetal het hoogst, waarbij er geen verschil bleek te zijn tussen bedrijven die onbeperkt weiden, beperkt weiden of jaarrond opstallen.

- Koeien met de hoogste dagelijkse melkproductie vertoonde de grootste stijging in celgetal tijdens warme perioden.

- Oudere koeien en laat-lactatie koeien hadden de grootste kans op een verhoogd celgetal.

- In één studie is onderzoek gedaan naar de bacteriële telling in melk welke een stijging liet zien tijdens warme perioden.

\section{Gezondheid}

- De incidentie van klinische mastitis was het hoogst in de periode december-januari, behalve voor Streptococcus uberis die het hoogst was in augustus. Een kleine piek in de incidentie van klinische mastitis was te zien in tweede helft van juli, voor bij bedrijven met de hoogste tankmelkcelgetal.

- Bij transitiekoeien blijkt in de zomer de conditiescore al voor het afkalven te dalen, terwijl dit in het voorjaar pas na het afkalven gebeurd. Tevens wijst één studie op het optreden van oxidatieve stress bij transitie koeien bij middelmatige hittestress.

- In één studie werd bij zomer afkalvende koeien een hogere vetaccumulatie in de lever waargenomen wat koeien gevoeliger maakt voor stofwisselingsziekten.

- De pH in de pens is lager bij hogere temperaturen. Ook bleek in één studie de ammoniakconcentratie en melkzuurconcentratie in de pens lager te zijn bij hogere temperaturen.

- Uit twee studies bleken er meer koeien te sterven onder zomerse condities.

- Na de zomer worden in de praktijk meer klauwproblemen waargenomen.

\section{Vruchtbaarheid}

- Er is een negatief effect van hittestress op het drachtigheidspercentage, waarbij de afname het sterkst is bij hoogproductieve koeien. Het effect is groter bij langdurige periode van hittestress dan bij een kortdurende periode.

- In één onderzoek scoorde KI slechter dan natuurlijke dekking en scoorde vers sperma beduidend slechter dan bevroren sperma. 


\section{Gedrag}

- Bij koeien die werden gemolken met een automatisch melksysteem (AMS) bleken tijdens warme perioden overdag meer tijd door te brengen in de stal, en 's nachts meer tijd in de wei.

- De voorkeur van koeien voor wei of stal blijkt niet altijd eenduidig te zijn met een toenemende THI, aangezien verschillende onderzoeken verschillende resultaten laten zien waarbij bedrijfsopzet en management van invloed lijken te zijn.

- Uit één studie bij jaarrond opgestalde koeien bleken koeien bij een toenemende THI meer te gaan staan en minder te gaan liggen.

\section{Voer- en wateropname}

- Vanaf een THI van circa 55-60 begint een afname in droge stof opname op te treden.

- In één studie met gegevens van melkkoeien over een periode 8 jaar werd bij een THI van 65 een circa $6 \%$ lagere droge stof opname gevonden en bij een THI van 74 een daling van circa $12 \%$.

- In één studie bij droge koeien in de late droogstand werd bij een THI van 76 een afname van $46 \%$ in droge stof opname gemeten, en bij koeien in de vroege lactatie een afname van $40 \%$.

- Vanaf een THI van 76 zijn metabolische verschuivingen van vet naar koolhydraten benutting vastgesteld.

- Er treedt een verandering op in eetgedrag door aanpassing van maaltijdgrootte, maaltijdduur en eetsnelheid.

- Het voermanagement blijkt van invloed te zijn op de ademhalingsfrequentie en rectale temperatuur.

- De wateropname neemt toe. In één studie bleek de wateropname lineair toe te nemen vanaf een THI van 35.

\section{Schaduwverstrekking}

- Schaduwverstrekking leidt tot een betere melkproductie, waarbij stijgingen tot $5 \%$ zijn gerapporteerd.

- Op basis van één studie lijkt schaduwverstrekking niet van invloed te zijn op de melksamenstelling.

- Schaduwverstrekking leidt tot lagere lichaams- en vaginale temperatuur, verlaging tot $0,3^{\circ} \mathrm{C}$.

- Schaduwverstrekking leidt tot lagere ademhalingsfrequentie, verlaging tot $30 \%$.

- Schaduwverstrekking leidt tot een betere panting score.

- Koeien maken gebruiken van kunstmatige schaduw als ze dat wordt aangeboden.

- Bij toenemende warmtebelasting neemt het gebruik van schaduw toe.

- Er worden verschillen in gedrag waargenomen, maar de resultaten zijn niet altijd significant.

- Koeien blijken voor een voorkeur te hebben voor schaduw boven sprinklers.

- Koeien blijken bij hoge temperaturen staan in de schaduw te verkiezen boven liggen op een plek zonder schaduw.

- De opname van krachtvoer neemt toe.

- Er wordt minder tijd gespendeerd bij de waterbak.

\section{Monitoring tools}

- Koesensoren kunnen worden gebruikt om vroegtijdige meldingen te geven van het optreden van hittestress.

Het aantal warme $\left(T>20^{\circ} \mathrm{C}\right)$, zomerse $\left(T>25^{\circ} \mathrm{C}\right)$, tropische $\left(T>30^{\circ} \mathrm{C}\right)$ dat een melkveebedrijf in gemiddeld jaar mee te maken hangt af de locatie van het bedrijf. Het zuidoosten heeft de meeste warme dagen en in het noordwesten en langs de kust het minste aantal dagen. Daarentegen het aantal zonnige dagen en de relatieve luchtvochtigheid het hoogst in de kustregio en neemt het landinwaarts af. De relatieve luchtvochtigheid is het laagst in de zomermaanden. De windsnelheid is het hoogst in de kustregio en neemt landinwaarts af.

De economische gevolgen van hittestress zijn sterk bedrijfsafhankelijk vanwege o.a. de locatie van het bedrijf in Nederland en de hoogte van de melkproductie. Voor een melkbedrijf met 100 melkkoeien en melkproductie van $8.500 \mathrm{~kg}$ melk per koe zijn indicatieve berekeningen gemaakt om een indruk te krijgen van de economische gevolgen van hittestress. De economische gevolgen bestaan enerzijds uit verminderde melkopbrengsten en anderzijds uit een toename in kosten, waarbij langetermijneffecten 
niet zijn meegenomen. Er zijn drie bedrijfsscenario's doorgerekend gebaseerd op het klimaat in Nederland: 1) weinig warme dagen, 2) gemiddeld aantal warme dagen, en 3) veel warme dagen. Weinige warme dagen geeft een kostenpost van circa $€ 3.000$, oplopend naar een kostenpost van circa $€ 5.600$ bij veel warme dagen voor een melkveebedrijf met 100 koeien, waarbij de verminderde melkopbrengsten de grootste kostenpost vormt.

Uit een workshop met mensen uit de melkveesector (melkveehouders, (voer)adviseurs, veeartsen en onderzoekers) aangevuld met informatie uit andere bronnen zijn de volgende oplossingsrichtingen naar voren gekomen:

- Aanpassen van het weidemanagement zoals bijvoorbeeld alleen 's avonds en nachts weiden.

- Benutten van de aanwezige variatie in de koppel koeien door bijvoorbeeld alleen de laagproductieve koeien te weiden tijdens warme perioden.

- Vermijden van additionele stress tijdens perioden van hittestress door bijvoorbeeld veebehandelingen op koelere momenten van de dag uit te voeren.

- Inzetten van monitoringtools als 'early warning' systeem om tijdig maatregelen te kunnen nemen.

- Aanpassen voeding door bijvoorbeeld beter verteerbaar voer te verstrekken en te zorgen voor goede drinkwatervoorzieningen

- Aanpassen inseminatiestrategie door bijvoorbeeld natuurlijke dekking i.p.v. KI toe te passen tijdens warme perioden.

- Aanpassen van het fokdoel door bijvoorbeeld meer rekening te houden met welke koeien beter om kunnen gaan met hoge temperaturen.

- Verstrekken van kunstmatige schaduw door bijvoorbeeld het gebruik van verplaatsbare schaduwdoeken.

- Verstrekking van schaduw door pleksgewijs zonnepanelen in de wei plaatsen.

- Koelen van koeien via bijvoorbeeld vernevelaars/sproeiers in de wei/kavelpad die aangaat als er een koe onderstaat (à la koeborstel).

- Verstrekken van schaduw via landschapsbomen

- Verstrekken van schaduw via voederbomen

- Zorgen voor een klimaatbestendig grasland door bijvoorbeeld grassenbestand uit te breiden met droogtetolerante, diep wortelende grassoorten.

- Voorkomen van (lokale) klimaatverandering door bijvoorbeeld vergroten van de duurzame energieproductie.

Uit de resultaten van het uitgevoerde literatuuronderzoek en de workshop zijn de verschillende kennishiaten naar voren gekomen. De belangrijkste kennishiaten liggen op de volgende terreinen:

- Vaststellen van een goede hittestress indicator met drempelwaarden voor de Nederlandse melkveehouderij.

- Gevolgen van hittestress op de melkproductie van droge koeien en nakomelingen.

- Vaststellen van de relatie tussen verhoogd celgetal in warme periode en optreden van (sub)klinische mastitis op korte en lange termijn.

- Gevolgen van hittestress op gezondheid (incl. weerstand) en het optreden van ziekten op de lange termijn.

- Welke fysiologische veranderingen treden op als gevolg van hittestress.

- Hoe kan het adaptief vermogen van koeien bij hittestress worden ingeschat.

- Wat zijn de gevolgen van hittestress op de opfokresultaten van jongvee.

- Vaststellen van de effecten van hittestress op de stierprestaties onder Nederlandse omstandigheden.

- Wanneer gaat de natuurlijke aanpassingsreactie van koeien bij warmte over in een situatie die schadelijk en belasting is voor de koe, en die gepaard gaat met ongerief.

- Vanaf welke temperatuur en/of zijn rantsoenaanpassingen zinvol en welke aanpassingen sorteren daadwerkelijk effect.

- Wat zijn goede vormen schaduwverstrekking en koelen in de wei en/of kavelpad en welk management is hiervoor nodig.

- Wanneer en welke aanpassingen in het vee- en weidemanagement zijn zinvol, met name rondom opstallen vs. weiden en beweidingsysteem.

- Wanneer en welke aanpassingen zijn nodig bij het management van jongvee, droge en transitiekoeien. 
- Welke maatregelen kan een veehouder nemen om te zorgen dat grasland goed blijft produceren ten tijde warme (en natte) perioden.

Uit de huidige verkennende studie is naar voren gekomen dat over de directe gevolgen van hittestress in gematigde klimaatstreken het nodige bekend is. Naar de indirecte gevolgen op langere termijn is weinig onderzoek gedaan. Aandachtspunten voor onderzoek naar langere termijn effecten zijn met name vruchtbaarheid, gezondheid en de effecten van hittestress tijdens droogstand en transitie op de volgende lactatie en kalfprestaties.

Aangezien de praktijk jaarlijks in het najaar te kampen heeft met meer problemen, verdient het aanbeveling om nader onderzoek te doen naar de onderliggende oorzaken van de zogenoemde (na)zomerdip. Dit vereist een integrale aanpak om de werkelijke oorzaken van de problemen boven tafel te krijgen. Naast het effect van hittestress op de koe dienen ook andere bedrijfsaspecten onder de loep te worden genomen zoals o.a. opslag en kwaliteit van voeding, drinkwaterkwaliteit, weidemanagement en bedrijfshygiëne. Hierbij zal ook de fysiologische achtergrond in ogenschouw dienen te worden om de onderliggende relaties te kunnen begrijpen.

Gezien de verwachte klimaatveranderingen zal de koe van de toekomst over een groter adaptief vermogen dienen te beschikken dan de huidige koe. Het uitvoeren van onderzoek naar de natuurlijke aanpassingsreactie van koeien (gedragsmatig en fysiologisch) bij warme, zomerse condities is zinvol om te bepalen wanneer er sprake is van een situatie die schadelijk en belastend is voor het dier, en die gepaard gaat met ongerief. Op basis hiervan kan het adaptief vermogen van koeien gaan worden ingeschat om zo te kunnen aangeven in welke mate koeien in staat zullen zijn om te gaan met veranderende weersomstandigheden en welke maatregelen veehouders kunnen nemen om daar op in te spelen.

Voor de praktijk spelen met name vragen rondom aanpassingen in het vee- en weidemanagement, en wijzigingen in het rantsoen, en schaduwverstrekking tijdens warme perioden. Praktijkonderzoek naar deze aspecten geeft veehouders meer inzicht in welke maatregelen effectief zijn, hoe ze dit kunnen integreren in hun bedrijfsvoering en wat de verwachte resultaten van deze maatregelen zijn. 


\section{$1 \quad$ Inleiding}

\section{$1.1 \quad$ Aanleiding}

Het klimaat in Nederland verandert. De gemiddelde temperatuur in De Bilt nam tussen 1901 en 2013 toe met $1,8^{\circ} \mathrm{C}$. Tussen 1951 en 2013 was de toename met $1,4^{\circ} \mathrm{C}$ het grootst. Ook is de jaarlijkse neerslag in Nederland gestegen met 26\% tussen 1910 en 2013, waarvan 14\% in de periode tussen 1951 en 2013. Alle seizoenen, behalve de zomer, zijn natter geworden. Daarbij is de zonnestraling vanaf de jaren '80 ook toegenomen, met 9\% tussen 1981 en 2013 (KNMI, 2017). De KNMIklimaatscenario's gaan uit van grotere kans op warmere zomers. Een gemiddeld jaar telt op het moment in De Bilt 85 warme dagen $\left(\mathrm{T}>20^{\circ} \mathrm{C}\right)$. Er is sprake van hittestress wanneer er een onbalans is tussen de warmteproductie in de koe en de mogelijkheid om deze warmte kwijt te raken aan de omgeving. Dit gebeurt zodra de bovenste kritische temperatuur van de thermoneutrale zone wordt overschreden, welke tussen de $20-24^{\circ} \mathrm{C}$ ligt voor Holstein koeien. Dit betekent dat op bijna een kwart van de dagen in het jaar in Nederland kans bestaat op hittestress. Als hittestress indicator wordt echter meestal de Temperatuur Luchtvochtigheid Index (THI) gebruikt. Het voordeel van deze indicator is dat makkelijk gemeten kan worden doordat alleen de temperatuur en relatieve luchtvochtigheid hoeft te worden gemeten. Echter zonne-instraling en windsnelheid worden in deze index niet meegenomen, maar zijn ook van invloed op de hittestress die een koe ervaart.

Oplopende temperaturen en toenemende zonnestraling zullen ervoor zorgen dat hittestress onder melkkoeien in Nederland vaker zal voorkomen. Met een veranderend en warmer wordend klimaat hebben alle melkkoeien en jongvee (weidend of niet weidend) te maken. Hittestress is daarom in het algemeen een aandachtspunt in de melkveehouderij in Nederland. Om hittestress in de stalomgeving te beperken zijn al verschillende opties (o.a. ventilatoren, dakisolatie en waterverneveling) beschikbaar (Versteeg, 2016). Men kan ervoor kiezen om tijdens zomerse $\left(\mathrm{T}>25^{\circ} \mathrm{C}\right)$ en tropische dagen $\left(\mathrm{T}>30^{\circ} \mathrm{C}\right)$ de koeien overdag binnen te houden om zo het effect van de zonne-instraling te verminderen, en 's avonds en 's nachts te weiden omdat het in de wei dan koeler is dan in de stal. Echter de Nederlandse Zuivelketen zet zich in voor het behoud van weidegang en werkt juist aan het verhogen van het percentage weidegang. Oplossingen die hittestress voorkomen of beperken tijdens weidegang dragen daarom bij aan het vergroten van het aantal weide uren per jaar, met meer vers gras in het rantsoen en een lagere ammoniakemissie per koe. Daarom is deze studie is specifiek gericht op het effect van hittestress bij weidegang en oplossingsrichtingen hiervoor.

Meer inzicht in de gevolgen van hittestress onder Nederlandse omstandigheden en de opties voor het reduceren van hittestress tijdens weidegang geeft veehouders de informatie die ze nodig hebben om weloverwogen keuzes te maken om maatregelen te nemen die renderen voor hun bedrijf en past in hun bedrijfsvoering om zo de koeien ook tijdens warme zomerse condities weidegang te kunnen blijven geven.

\subsection{Doel}

Het doel van het beschreven onderzoek was inzicht verkrijgen in wat er wel/niet bekend is over de effecten van hittestress tijdens weidegang op de melkproductie, gezondheid en welzijn van melkkoeien onder Nederlandse omstandigheden en de economische gevolgen daarvan. Verder is er een verkenning uitgevoerd naar opties om de effecten van hittestress tijdens weidegang te reduceren. 


\subsection{Afbakening}

Het doel van deze verkennende studie was specifiek gericht op hittestress bij weidegang en niet op hittestress bij huisvesting van melkvee en/of jongvee in gematigde klimaatstreken.

Vanwege de beperkte omvang van het project was er geen ruimte om hittestress in een stalomgeving in de beschouwing mee te nemen, ondanks dat hittestress bij warme zomerse condities ook optreedt in een stalomgeving. Daarbij zijn er al verschillende opties (o.a. ventilatoren, dakisolatie en waterverneveling) beschikbaar om hittestress in een stalomgeving te beperken (Versteeg, 2016). Desalniettemin zal bij een warmer wordend klimaat hittestress bij opstallen van melkvee ook een groter aandachtspunt worden. Bij het verkennende literatuuronderzoek is specifiek gezocht op artikelen die gingen over hittestress bij melkvee bij weidegang, grazen of gematigde klimaatstreken. $\mathrm{Er}$ is geen strikt onderscheid gemaakt in resultaten van bedrijven die wel/niet weiden, aangezien het niet altijd mogelijk was om zo'n strikte scheiding te hanteren. Zo worden bijvoorbeeld zijn bij dataanalyses zowel weidende als niet-weidende bedrijven meegenomen, en ook staat niet altijd vermeld of koeien weidegang kregen tijdens het onderzoek. Bij de resultaten van het literatuuronderzoek in hoofdstuk 2 zitten daardoor ook resultaten van onderzoeken in gematigde klimaatstreken waarbij de koeien jaarrond op stal stonden.

Het literatuuronderzoek was specifiek gericht op resultaten uit gematigde klimaatstreken die ongeveer vergelijkbare klimaatomstandigheden kennen als in Nederland. Een recente review van de internationale onderzoeksliteratuur door Van Laer et al. (2014) liet zien dat traditionele klimaatindexen en drempelwaarden voor hittestress verouderd zijn, te sterk zijn gefocust op hete klimaten en te algemeen zijn om hittestress te evalueren van de verschillende (met name hoogproductieve) koeienrassen die hedendaags worden gebruikt in gematigde streken. Het klimaat in (sub)tropische klimaatstreken kent veel langere periodes met hoge temperaturen $\left(\mathrm{T}>30^{\circ} \mathrm{C}\right)$, hoge nachttemperaturen $\left(\mathrm{T}>20^{\circ} \mathrm{C}\right)$ en lage luchtvochtigheid die sterk verschillen van het klimaat in Nederland. Verder speelt mee dat de bedrijfsopzet in (sub)tropische klimaten sterk afwijkt van de bedrijfsopzet in Nederland. Zo worden er de koeien vaak niet geweid en wordt veelvuldig rantsoenen zonder gras gevoerd, terwijl in Nederland circa $80 \%$ van de veehouders zijn koeien weidt en op bijna alle bedrijven in gras(kuil) in het rantsoen zit. Daarom zijn de onderzoeksresultaten uit (sub)tropische klimaatstreken niet meegenomen in deze studie. 


\section{Hittestress bij melkvee in gematigde klimaten}

In dit hoofdstuk staan de resultaten beschreven van het literatuuronderzoek naar de effecten van hittestress op de melkproductie, gezondheid en welzijn bij melkvee in gematigde klimaatstreken. Voor een uitgebreid overzicht van de algemene kennis over de effecten van hittestress op de productiviteit van rundvee wordt verwezen naar het boek 'Heat Stress and Animal Productivity' van Aggarwal en Upadhyay (2013). Zij geven een uitgebreid overzicht van de effecten van hittestress op de regulatie van hormonen, melkproductie, reproductie, immuun functie en biologische ritmes van rundvee.

\subsection{Hittestress indicatoren}

Hittestress wordt in het algemeen gedefinieerd als een situatie waarbij sprake is van een onbalans tussen de warmteproductie van de koe en de mogelijkheid om deze warmte kwijt te raken aan de omgeving. Dit gebeurt zodra de bovenste kritische temperatuur van de thermoneutrale zone wordt overschreden. De bovenste kritieke temperatuur is geschat op basis van onderzoek in klimaatkamers en ligt voor Holstein koeien tussen de $20-24^{\circ} \mathrm{C}$, en voor Jersey en kruisling-koeien tussen $24-28^{\circ} \mathrm{C}$. Voor het bepalen of een klimaatomgeving hittestress kan veroorzaken in koeien wordt gebruikt gemaakt van hittestress indicatoren zoals de Temperatuur Luchtvochtigheid Index (THI). De THI gebruikt de twee belangrijkere en makkelijk te meten parameters, namelijk temperatuur en relatieve luchtvochtigheid, om het effect van het klimaat op de dierrespons te meten (Aggarwal en Upadhyay, 2013). De THI is de meest gebruikte index voor het classificeren van matige tot hete condities. Er komen verschillende variaties voor van de definitie voor de berekening van de THI waarbij onderzoekers andere coëfficiënten gebruiken voor de berekening van de THI wat mede afhangt van of de schaal in Celsius of Fahrenheit is. Dit bemoeilijkt echter het onderling vergelijken van onderzoeksresultaten. Zo geeft Van Laer et al. (2015a) de volgende formule voor de berekening van de THI:

$$
\mathrm{THI}=0,8 \times \mathrm{T}+((\mathrm{RV} / 100) \times(\mathrm{T}-14,4))+46,4 .
$$

Terwijl bijvoorbeeld Brügemann et al. (2013) de volgende formule hanteren: $\mathrm{THI}=(1,8 \times \mathrm{T}+32)-(0,55-0,0055 \times \mathrm{RV}) \times(1,8 \times \mathrm{T}-26)$.

In beide formules zijn de definities van de symbolen als volgt:

$\mathrm{THI}=$ Temperatuur luchtvochtigheid index (Temperature Humidity Index),

$\mathrm{RV}=$ Relatieve luchtvochtigheid (in \%),

$\mathrm{T}=$ Luchttemperatuur $\left(\right.$ in ${ }^{\circ} \mathrm{C}$ ).

Algemeen wordt aangenomen dat negatieve effecten optreden vanaf een THI van 72 of zelfs 74, maar deze zijn gebaseerd op oude onderzoeksresultaten van koeien die een aanzienlijk lagere melkproductie hadden dan de huidige koeien. Voor West-Europese Holstein koeien is een drempelwaarde voor 62 voor de THI voorgesteld op basis van recent onderzoek door Van Laer et al. (2014). Onderzoek in Nedersaksen gaf vergelijkbare resultaten te zien. Bij een THI van hoger dan 60 namen de melkproductie en voeropname af (Gorniak et al., 2014). Zom (2016) geeft de volgende drempelwaarden voor de THI aan:

- THI $<68$ Geen hittestress

- THI 68-75 Milde hittestress

- THI 76-85 Hittestress

- THI 85-95 Ernstige hittestress

- $\mathrm{THI}>95 \quad$ Dodelijke hittestress

Op basis de THI-formule van Van Laer et al. (2015a) en de drempelwaarden van Zom (2016) is de THI-tabel in figuur 1 samengesteld. 


\begin{tabular}{|c|c|c|c|c|c|c|c|c|c|c|c|c|c|c|c|c|c|c|c|c|c|}
\hline \multirow{2}{*}{$\begin{array}{c}\text { Temp. } \\
\left({ }^{\circ} \mathrm{C}\right)\end{array}$} & \multicolumn{21}{|c|}{ Relatieve Luchtvochtigheid (\%) } \\
\hline & 0 & 5 & 10 & 15 & 20 & 25 & 30 & 35 & 40 & 45 & 50 & 55 & 60 & 65 & 70 & 75 & 80 & 85 & 90 & 95 & 100 \\
\hline 15 & 58 & 58 & 58 & 58 & 59 & 59 & 59 & 59 & 59 & 59 & 59 & 59 & 59 & 59 & 59 & 59 & 59 & 59 & 59 & 59 & 59 \\
\hline 16 & 59 & 59 & 59 & 59 & 60 & 60 & 60 & 60 & 60 & 60 & 60 & 60 & 60 & 60 & 60 & 60 & 60 & 61 & 61 & 61 & 61 \\
\hline 17 & 60 & 60 & 60 & 60 & 61 & 61 & 61 & 61 & 61 & 61 & 61 & 61 & 62 & 62 & 62 & 62 & 62 & 62 & 62 & 62 & 63 \\
\hline 18 & 61 & 61 & 61 & 61 & 62 & 62 & 62 & 62 & 62 & 62 & 63 & 63 & 63 & 63 & 63 & 64 & 64 & 64 & 64 & 64 & 64 \\
\hline 19 & 62 & 62 & 62 & 62 & 63 & 63 & 63 & 63 & 63 & 64 & 64 & 64 & 64 & 65 & 65 & 65 & 65 & 66 & 66 & 66 & 66 \\
\hline 20 & 62 & 63 & 63 & 63 & 64 & 64 & 64 & 64 & 65 & 65 & 65 & 65 & 66 & 66 & 66 & 67 & 67 & 67 & 67 & 68 & 68 \\
\hline 21 & 63 & 64 & 64 & 64 & 65 & 65 & 65 & 66 & 66 & 66 & 67 & 67 & 67 & 67 & 68 & 68 & 68 & 69 & 69 & 69 & 70 \\
\hline 22 & 64 & 64 & 65 & 65 & 66 & 66 & 66 & 67 & 67 & 67 & 68 & 68 & 69 & 69 & 69 & 70 & 70 & 70 & 71 & 71 & 72 \\
\hline 23 & 65 & 65 & 66 & 66 & 67 & 67 & 67 & 68 & 68 & 69 & 69 & 70 & 70 & 70 & 71 & 71 & 72 & 72 & 73 & 73 & 73 \\
\hline 24 & 66 & 66 & 67 & 67 & 68 & 68 & 68 & 69 & 69 & 70 & 70 & 71 & 71 & 72 & 72 & 73 & 73 & 74 & 74 & 75 & 75 \\
\hline 25 & 66 & 67 & 67 & 68 & 69 & 69 & 70 & 70 & 71 & 71 & 72 & 72 & 73 & 73 & 74 & 74 & 75 & 75 & 76 & 76 & 77 \\
\hline 26 & 67 & 68 & 68 & 69 & 70 & 70 & 71 & 71 & 72 & 72 & 73 & 74 & 74 & 75 & 75 & 76 & 76 & 77 & 78 & 78 & 79 \\
\hline 27 & 68 & 69 & 69 & 70 & 71 & 71 & 72 & 72 & 73 & 74 & 74 & 75 & 76 & 76 & 77 & 77 & 78 & 79 & 79 & 80 & 81 \\
\hline 28 & 69 & 69 & 70 & 71 & 72 & 72 & 73 & 74 & 74 & 75 & 76 & 76 & 77 & 78 & 78 & 79 & 80 & 80 & 81 & 82 & 82 \\
\hline 29 & 70 & 70 & 71 & 72 & 73 & 73 & 74 & 75 & 75 & 76 & 77 & 78 & 78 & 79 & 80 & 81 & 81 & 82 & 83 & 83 & 84 \\
\hline 30 & 70 & 71 & 72 & 73 & 74 & 74 & 75 & 76 & 77 & 77 & 78 & 79 & 80 & 81 & 81 & 82 & 83 & 84 & 84 & 85 & 86 \\
\hline 31 & 71 & 72 & 73 & 74 & 75 & 75 & 76 & 77 & 78 & 79 & 80 & 80 & 81 & 82 & 83 & 84 & 84 & 85 & 86 & 87 & 88 \\
\hline 32 & 72 & 73 & 74 & 75 & 76 & 76 & 77 & 78 & 79 & 80 & 81 & 82 & 83 & 83 & 84 & 85 & 86 & 87 & 88 & 89 & 90 \\
\hline 33 & 73 & 74 & 75 & 76 & 77 & 77 & 78 & 79 & 80 & 81 & 82 & 83 & 84 & 85 & 86 & 87 & 88 & 89 & 90 & 90 & 91 \\
\hline 34 & 74 & 75 & 76 & 77 & 78 & 79 & 79 & 80 & 81 & 82 & 83 & 84 & 85 & 86 & 87 & 88 & 89 & 90 & 91 & 92 & 93 \\
\hline 35 & 74 & 75 & 76 & 77 & 79 & 80 & 81 & 82 & 83 & 84 & 85 & 86 & 87 & 88 & 89 & 90 & 91 & 92 & 93 & 94 & 95 \\
\hline 36 & 75 & 76 & 77 & 78 & 80 & 81 & 82 & 83 & 84 & 85 & 86 & 87 & 88 & 89 & 90 & 91 & 92 & 94 & 95 & 96 & 97 \\
\hline 37 & 76 & 77 & 78 & 79 & 81 & 82 & 83 & 84 & 85 & 86 & 87 & 88 & 90 & 91 & 92 & 93 & 94 & 95 & 96 & 97 & 99 \\
\hline 38 & 77 & 78 & 79 & 80 & 82 & 83 & 84 & 85 & 86 & 87 & 89 & 90 & 91 & 92 & 93 & 95 & 96 & 97 & 98 & 99 & 100 \\
\hline 39 & 78 & 79 & 80 & 81 & 83 & 84 & 85 & 86 & 87 & 89 & 90 & 91 & 92 & 94 & 95 & 96 & 97 & 99 & 100 & 101 & 102 \\
\hline 40 & 78 & 80 & 81 & 82 & 84 & 85 & 86 & 87 & 89 & 90 & 91 & 92 & 94 & 95 & 96 & 98 & 99 & 100 & 101 & 103 & 104 \\
\hline
\end{tabular}

Figuur 1 Temperatuur Luchtvochtigheid Index op basis van de formule zoals gebruikt door Van Laer et al. (2015a) met de drempelwaarde van Zom (2016) waarbij: groen = geen hittestress, geel = milde hittestress, oranje $=$ hittestress, donkeroranje $=$ ernstige hittestress, rood $=$ dodelijke hittestress.

Een index die ook wordt gebruikt is de warmte belasting index (HLI) (Van Laer et al., 2015a):

$$
\begin{array}{ll}
\mathrm{HLI}=8,62+0,38 \times \mathrm{RH}+1,55 \times \mathrm{Tbg}-0,5 \times \mathrm{WS}+\mathrm{e}^{(2,4-\mathrm{WS})} & \text { voor } \mathrm{Tbg}>25 \\
\mathrm{HLI}=10,66+0,28 \times \mathrm{RH}+1,3 \times \mathrm{Tbg}-\mathrm{WS} & \text { voor } \mathrm{Tbg}<25
\end{array}
$$

De definities van de symbolen zijn als volgt:

HLI = Warmte Belasting Index (heat load index)

$\mathrm{RH}=$ Relatieve luchtvochtigheid (in \%)

Tbg = Zwarte bol temperatuur $\left(\right.$ in ${ }^{\circ} \mathrm{C}$ )

\begin{tabular}{|c|c|c|c|c|c|c|c|c|c|c|c|c|c|c|c|c|c|c|c|c|c|c|c|}
\hline \multicolumn{24}{|c|}{ Heat Load Index (HLI) } \\
\hline \multirow{2}{*}{ windsnelheid } & \multirow{2}{*}{\begin{tabular}{|l|l}
$\mathrm{km}$ \\
$/ \mathrm{h}$
\end{tabular}} & \multirow{2}{*}{$\begin{array}{l}\mathrm{m} \\
/ \mathrm{sec}\end{array}$} & \multicolumn{21}{|c|}{ Zwarte bol temperatuur (ZBT) in ${ }^{\circ} \mathrm{C}$} \\
\hline & & & 20 & 21 & 22 & 23 & 24 & 25 & 26 & 27 & 28 & 29 & 30 & 31 & 32 & 33 & 34 & 35 & 36 & 37 & 38 & 39 & 40 \\
\hline kleine takken & 36 & 10 & 46 & 48 & 49 & 50 & 51 & 53 & 71 & 72 & 74 & 75 & 77 & 78 & 80 & 81 & 83 & 84 & 86 & 88 & 89 & 91 & 92 \\
\hline bewegen & 18 & 5 & 51 & 53 & 54 & 55 & 56 & 58 & 73 & 75 & 76 & 78 & 79 & 81 & 82 & 84 & 85 & 87 & 89 & 90 & 92 & 93 & 95 \\
\hline twijgen bewegen & 14 & 4 & 52 & 54 & 55 & 56 & 57 & 59 & 74 & 75 & 77 & 78 & 80 & 81 & 83 & 85 & 86 & 88 & 89 & 91 & 92 & 94 & 95 \\
\hline wind merkbaar, & 11 & 3 & 53 & 55 & 56 & 57 & 58 & 60 & 75 & 76 & 78 & 79 & 81 & 82 & 84 & 85 & 87 & 89 & 90 & 92 & 93 & 95 & 96 \\
\hline bladeren ritselen & 7 & 2 & 54 & 56 & 57 & 58 & 59 & 61 & 76 & 78 & 79 & 81 & 82 & 84 & 85 & 87 & 88 & 90 & 92 & 93 & 95 & 96 & 98 \\
\hline bladeren bewegen & 4 & 1 & 55 & 57 & 58 & 59 & 60 & 62 & 79 & 81 & 82 & 84 & 85 & 87 & 88 & 90 & 91 & 93 & 95 & 96 & 98 & 99 & 101 \\
\hline niet & 0 & 0 & 56 & 58 & 59 & 60 & 61 & 63 & 87 & 88 & 90 & 91 & 93 & 94 & 96 & 97 & 99 & 100 & 102 & 104 & 105 & 107 & 108 \\
\hline \multicolumn{24}{|c|}{ bij \% luchtvochtigheid $=70$} \\
\hline \multicolumn{24}{|c|}{$\begin{array}{l}\text { Hittestress-graad stijgt naarmate de kleur donkerder wordt } \\
\text { Gaughan et al. (2008) ontwikkelden volgende classificatie: }\end{array}$} \\
\hline $\begin{array}{l}\text { HLI } \leq 70 \text { : } \\
\text { Thermoneutrale } \\
\text { omstandigheden, } \\
\text { geen hittestress. }\end{array}$ & & & \multicolumn{6}{|c|}{$\begin{array}{l}70<\mathrm{HLI} \leq 77: \\
\text { Warme omstandigheden, } \\
\text { milde hittestress }\end{array}$} & \multicolumn{9}{|c|}{$\begin{array}{l}77<\mathrm{HLI} \leq 86: \\
\text { Hete omstandigheden, } \\
\text { ernstige hittestress }\end{array}$} & \multicolumn{6}{|c|}{$\begin{array}{l}\text { HLI > 86: } \\
\text { Zeer hete omstandigheden, } \\
\text { zeer ernstige / extreme hittestress }\end{array}$} \\
\hline
\end{tabular}

WS $=$ Windsnelheid (in $\mathrm{m} / \mathrm{s}$ )

Figuur 2 Waarde van warmte belasting index voor Belgische zomers (Van Laer et al., 2015b).

Voor de warmte belasting index is er vanaf een waarde van 70 sprake van milde hittestress, welke gebaseerd is op onderzoek bij vleesvee in een feedlot, zie figuur 2 (Van Laer et al., 2015b). Door Hammami et al. (2013) wordt voor West-Europese Holstein koeien een waarde van 80 voor de HLI als bovengrens van de thermo neutrale zone gehanteerd. Het nadeel van de warmte belasting index is de abrupte overgang bij $25^{\circ} \mathrm{C}$ doordat boven de $25^{\circ} \mathrm{C}$ een andere formule wordt gehanteerd dan onder de $25^{\circ} \mathrm{C}$. 
De Panting Score (PS) is een methode om de mate van hittestress die koeien ervaren te scoren. De score is gebaseerd op de intensiteit waarmee een koe reageert om de overtollige warmte kwijt te raken via haar ademhaling, lichaamshouding, hijgen en kwijlen. De score gaat van 0 (normale ademhaling, niet hijgen of kwijlen) tot 4,5 (overmatig kwijlen met de bek open, de tong volledig uit en uitgestrekte nek). Een score gelijk aan of hoger dan 2 bij $10 \%$ of meer van de koeien wordt als grenswaarde gehanteerd om ernstig thermisch discomfort te definiëren. De overgang van score 2,5 naar 4,5 kan bij ernstige hitte heel snel gebeuren. Wanneer $10 \%$ van de kudde een score van 3,5 of hoger heeft, is er een verhoogde kans op sterfte (Van Laer et al., 2015b).

De belangrijkste resultaten t.a.v. hittestress indicatoren zijn:

- De Temperatuur Luchtvochtigheid Index (THI), gebaseerd temperatuur en luchtvochtigheid, is de meest gebruikte hittestress indicator. Het voordeel van de THI is dat deze makkelijk is te meten, maar de nadelen zijn dat de zonne-instraling en windsnelheid ontbreken in deze indicator en dat er verschillende formules zijn om de THI te berekenen.

- $\mathrm{Er}$ is geen eenduidige beeld over vanaf welke drempelwaarde negatieve effecten optreden. Negatieve effecten beginnen over het algemeen op te treden tussen een THI van 60 à 70 .

\subsection{Effect op melkproductie en uiergezondheid}

\section{Melkproductie}

Uit een data-analyse van 47 Nederlandse melkveebedrijven bleek dat tijdens warme periodes een daling in melkproductie optrad. In 1995, 1996 en 1997 was de daling respectievelijk -4,0\%, -5,4\% en $-12,5 \%$. Tevens bleek uit de data-analyse dat de daling in melkproductie het grootst was bij de hoogst producerende koeien $(-12,8 \%)$ en het laagst voor de laagst producerende dieren $(-4,0 \%)$. Er werd geen effect van pariteit gevonden op afname in melkproductie tijdens warme perioden (Hogeveen et al., 2001). Uit een data-analyse in Nieuw-Zeeland van eerstekalfs koeien van 496 melkveebedrijven over de periode 1990-2002 kwam naar voren dat hete condities leidden tot een lagere melkproductie. Afname begon voor Holstein Friesian (HF) koeien bij een lagere 3-daagse THI-gemiddelde dan bij kruislingen (HF x NZJ) of bij Nieuw-Zeelandse Jersey (NZJ) koeien, zie figuur 2. Echter de melkproductie van de HF-koeien was ook het hoogst, terwijl de melkproductie van NZJ-koeien het laagst was (Bryant et al., 2007). Uit een Italiaanse data-studie naar melkgegevens van 484 melkveebedrijven over de periode 2002-2007 bleek het effect van hittestress af te hangen van de pariteit. Eerste kalfskoeien bleken minder gevoelig te zijn dan $2^{\mathrm{e}}$ of $3^{\mathrm{e}}$ kalfskoeien. Productiedalingen per dag liepen tot op $0,91 \mathrm{~kg}(-3,1 \%)$ bij gemiddeld $29,5 \mathrm{~kg}$ melk voor $1^{\mathrm{e}}$ kalfskoeien, $1,16 \mathrm{~kg}$ ($3,4 \%)$ bij gemiddeld $33,7 \mathrm{~kg}$ melk voor $2^{\mathrm{e}}$ kalfskoeien, en $1,27 \mathrm{~kg}(-3,7 \%)$ bij een gemiddelde melkproductie van 34,7 kg voor $3^{e}$ kalfskoeien (Bernabucci et al., 2014).

Voor zes Nederlandse melkveeproefbedrijven zijn de melkgegevens over de periode 2003-2006 geanalyseerd met behulp van een dynamisch lineair model voor tijdserie analyses o.b.v. dagelijkse melkproductie en dagelijkse buitentemperatuur van het dichtstbijzijnde weerstation. Er bleek een negatief effect op de melkproductie op te treden als de gemiddelde dagtemperatuur boven een bepaalde kritieke temperatuur uit kwam. Het bleek dat de kritieke temperatuur waarboven een daling in melkproductie optrad varieerde per bedrijf, van 16 tot $20^{\circ} \mathrm{C}$. Ook het gemiddelde productieverlies varieerde per bedrijf, van 4 tot $72 \mathrm{~kg}$ melk/koe per jaar alsmede de duur van de periode van hittestress, die varieerde van 3 tot 9 dagen. Het gemiddelde productieverlies bedroeg 31,4 kg per melkkoe per jaar wat neer kwam op $0,32 \%$ van de gemiddelde productie van $9.855 \mathrm{~kg} / \mathrm{koe}$. Het gebruikte dynamische lineaire model kan ook op individueel niveau worden gebruikt om de koespecifieke gevolgen van hittestress te schatten (André et al., 2011). Uit onderzoek in Schotland bleek dat de effecten van hittestress, daling in melkproductie, vet- en eiwitgehalte, verschilden afhankelijk van of de koeien jaarrond op stal stonden of ook werden geweid in de zomerperiode (Hill en Wall, 2014). Verder bleek uit onderzoek in Nedersaksen dat de afname in melkproductie verschilde per regio $(-0,08 \mathrm{~kg} / \mathrm{THI}$ tot $-0,47 \mathrm{~kg} / \mathrm{THI}$ en was het grootst voor bedrijven die in de kustregio waren gesitueerd (Brügemann et al., 2012). Daarentegen werd door Lambertz et al. (2014) geen significant verschillend effect van hittestress op de melkproductie waargenomen tussen bedrijven in Nedersaksen met wel/geen geïsoleerde dak en wel/niet weiden van de koeien. 
Belgisch onderzoek in 2011 en 2013 bij een melkveeproefbedrijf met weidegang gaf een lichte daling in melkgift (tot 1 liter/koe per dag) te zien als gevolg van hittestress (Van Laer et al., 2015b). Een data-analyse van 604 Belgische en Duitse melkveebedrijven gaf een afname in melkproductie te zien van 0,164 kg melk/THI per koe per dag bij milde hittestress, 0,365 kg melk/THI per koe per dag bij matige hittestress en 0,955 kg melk/THI per koe per dag bij hoge hittestress (Hammami et al., 2013). Uit onderzoek op een commercieel Italiaans melkveebedrijf bleek de melkproductie in de periode na afkalven van transitiekoeien die in het voorjaar afkalfden aanzienlijk hoger (14 tot 38\%) te zijn dan bij transitiekoeien die in zomer afkalfden en te maken hadden gehad met drie perioden met minimaal drie achtereenvolgende dagen waarin de hersteltijd ( THI < 72) minder dan 10 uur was (Basiricò et al., 2009). Op een Italiaans commercieel melkveebedrijf met jaarrond opstallen bleken de koeien die in de zomer halverwege de lactatie zaten een lagere melkproductie $(-10 \%)$ te hebben dan koeien die in het voorjaar halverwege de lactatie zaten (Bernabucci et al., 2002).

De belangrijkste resultaten t.a.v. melkproductie zijn:

- Hittestress zorgt voor een daling in melkproductie, waarbij dalingen tot $-12 \%$ zijn gerapporteerd. Hoe hoger de THI, des te groter de daling in melkproductie was.

- Er blijkt een bedrijfseffect te zijn.

- De daling in melkproductie is het grootst bij melkkoeien met de hoogste dagelijkse melkproductie en het laagst voor koeien met de laagste dagproductie.

- Melkvaarzen blijken minder gevoelig te zijn dan $2^{\mathrm{e}}$ of $3^{\mathrm{e}}$ kalfskoeien.

- Jersey koeien vertoonden een minder grote daling dan Holstein koeien, maar daarentegen was de melkproductie van Jersey koeien ook lager.

\section{Melksamenstelling}

Naast een daling in melkproductie laten de meeste onderzoeksresultaten zien dat er een daling optreed in het vet- en eiwitgehalte als gevolg van hittestress (Bryant et al., 2007; Gorniak et al., 2014; Hammami et al., 2013; Lambertz et al., 2014), terwijl in een enkel geval het effect op het vetpercentage afhing van de regio (Brügemann et al., 2012). Uit Nieuw-Zeelands onderzoek bleek dat de afname afhing van het ras. Afnames van meer dan $1 \%$ in melkbestanddelen (eiwit, vet en lactose) per eenheid toename in THI begon voor Holstein Friesian (HF) bij een 3-daagse gemiddelde THI van 68, bij kruislingen (HF x NZJ) bij 69, en bij Nieuw-Zeelandse Jersey (NZJ) bij 75. Echter de melkproductie van de HF-koeien was ook het hoogst, terwijl de melkproductie van NZJ-koeien het laagst was. In figuur 2 staan het effect van de THI op de gemiddelde melkopbrengst, vet- en eiwitgehalte en melkbestanddelen weergegeven uit deze studie. Het vetgehalte bij de Holstein-Friesian neemt lineair af van circa 4,9\% bij een THI van 45 naar circa 4,1\% bij een THI van 85 (een daling van circa 16\%). Bij de kruislingen stijgt het vetgehalte licht van circa 5,0\% bij een THI van 45 naar circa $5,1 \%$ bij een THI van 60 waarna het vervolgens daalt naar circa 4,6\% bij een THI van 85 . Bij de Nieuw-Zeelands Jerseys stijgt het vetgehalte van circa 5,1\% bij een THI van 45 naar circa 5,7\% bij een THI van 65 waarna het daalt naar circa 5,1\% bij een THI van 85. Het eiwitgehalte bij de HolsteinFriesian daalt van circa 3,6\% bij een THI van 45 naar circa 3,0\% bij een THI van 85 (een daling van circa 17\%). Bij de kruislingen stijgt het eiwitgehalte van circa 3,4\% bij een THI van 45 naar circa $3,7 \%$ bij een THI van 63 waarna het vervolgens daalt naar 3,2\% bij een THI van 85 . Bij de NieuwZeelands Jerseys stijgt het eiwitgehalte van circa 3,5\% bij een THI van 45 naar circa 4,0\% bij een THI van 66 waarna het daalt naar circa 3,5\% bij een THI van 85 (Bryant et al., 2007).
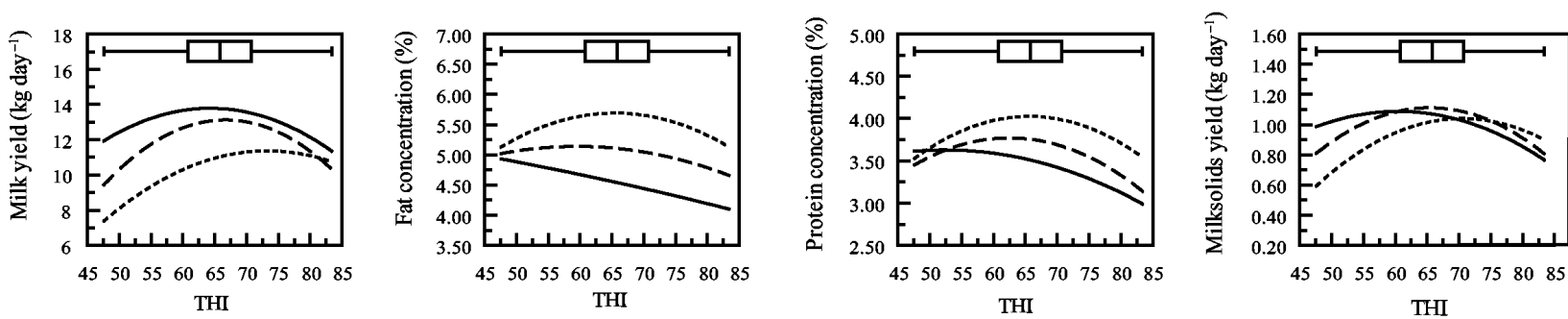

Figuur 3 Het effect van de THI op de gemiddelde melkopbrengst, vet- en eiwitgehalten en melkbestanddelen voor Holstein-Friesian (HF; ononderbroken lijn), kruisling (HFXNZJ; streepjeslijn) en Nieuw-Zeelandse Jersey (NZJ; stippellijn) (Bryant et al., 2007). 
Bij Duitse Holstein koeien nam het eiwit- en vetpercentage continu af bij een toenemende THI. Uitgaande van een gemiddeld vetgehalte van $4,3 \%$ en een gemiddeld eiwitgehalte van 3,5\% dan daalde in het traject van THI 30 tot 75 het vetgehalte met bijna 5\% en het eiwitgehalte met bijna $6 \%$ (Gorniak et al., 2014). In een andere studie met Holstein-Friesian koeien werd ook een negatief effect gevonden op het vet- en eiwitgehalte bij een toenemende THI. Het vetgehalte daalde met circa 4 tot $12 \%$ en eiwitgehalte daalde met circa 5 tot $7 \%$ in het traject van THI 45 tot 85 afhankelijk van de mate van isolatie van de stal en of er wel/niet werd beweidt (Lambertz et al., 2014). Bij Italiaanse Holstein koeien nam het eiwitpercentage af met $-0,02$ tot $-0,10 \%$ tijdens een periode van hittestress, waarbij de $2^{\mathrm{e}}$ en $3^{\mathrm{e}}$ kalfskoeien een hogere afname hadden dan $1^{\mathrm{e}}$ kalfskoeien. Het vetgehalte was in deze studie niet gerapporteerd (Bernabucci et al., 2014). Uit een data-analyse van de melksamenstelling van Italiaanse koeien over de periode 2003-2009 werd vanaf een THI max 50 een daling in het vetpercentage waargenomen van 4,00 naar 3,60\% bij een THI van 85 (een daling van $10 \%$ ), en vanaf een $\mathrm{THI}_{\max } 65$ een daling in het eiwitgehalte van 3,44 naar 3,26\% bij een THI van 85 (een daling van 5\%) (Bertocchi et al., 2014). Ook bleek bij opgestalde Italiaanse Holstein koeien die in de zomer halverwege de lactatie zaten hadden een 9,9\% lager eiwitgehalte hadden in vergelijking tot het eiwitgehalte in het voorjaar (3,31\% vs. 3,01\% respectievelijk). Ook het caseïne gehalte en caseïne getal waren lager in de zomer dan in het voorjaar, terwijl de melkserum eiwitten hoger waren. Het a-caseïne en $\beta$-caseïne gehalte waren ook lager, maar niet het $\mathrm{k}$-caseïne gehalte (Bernabucci et al., 2002).

De belangrijkste resultaten t.a.v. melksamenstelling zijn:

- Hittestress heeft een negatief effect op het vet- en eiwitgehalte in de melk, waarbij dalingen tot $16 \%$ en $-17 \%$ respectievelijk zijn vastgesteld. Hoe hoger de THI, des te groter de daling in gehalten was.

- Jersey koeien vertoonden een minder grote daling in gehalten dan Holstein koeien.

- In één studie zijn negatieve effecten op het caseïne-gehalte vastgesteld.

\section{Celgetal}

Uit onderzoek eind jaren '90 bleek dat warme perioden in Nederland leidde tot een hoger celgetal in de melk ( +8 tot $15 \%$ ). De koeien met de hoogste melkproductie ( $>35 \mathrm{~kg} / \mathrm{dag}$ ) hadden de grootste toename in celgetal $(+21 \%)$. De pariteit van de koeien bleek ook van invloed te zijn, waarbij de oudste koeien (pariteit $\geq 4$ ) de grootste toename in celgetal (28\%) hadden (Hogeveen et al., 2001). Uit een data-analyse van 300 Nederlands melkveebedrijven over een periode van vier jaar (19921995) bleek er een seizoenseffect te zijn op het tankmelkcelgetal en individuele koe melkcelgetal. Het tankmelkcelgetal was in alle jaren het hoogst in de periode augustus-september. Het gemiddelde tankmelkcelgetal van alle bedrijven over de gehele onderzoeksperiode bedroeg $187.000 \mathrm{cellen} / \mathrm{ml}$. De seizoen variatie varieerde tussen 26.000 cellen/ml (13,9\%) in 1993 en 59.000 cellen/ml (31,6\%) in 1995. Er werd geen verschil gevonden in tankmelkcelgetal tussen bedrijven met onbeperkt weiden, beperkt weiden en jaarrond opstallen. Voor individuele koeien was de kans op het krijgen van een verhoogd melkcelgetal was het hoogst in augustus, terwijl in mei de kans het grootst was op het aanhouden van een verhoogd melkcelgetal. Oudere koeien en laat-lactatie koeien hadden een grotere kans op het krijgen of aanhouden van een verhoogd celgetal in de melk (Olde Riekerink et al., 2007). Uit onderzoek in Nedersaksen bleek dat de toename in celgetal verschilde tussen drie regio's en bleek de toename het grootst te zijn voor de bedrijven die in de kustregio (gekarakteriseerd door weidebedrijven) waren gesitueerd, terwijl in de inlands-regio (gekarakteriseerd door weidebedrijven) en de akkerbouw-regio (gekarakteriseerd door bedrijven die opstallen) nauwelijks een toename was in celgetal (Brügemann et al., 2012). Bij een andere studie bij Duitse Holstein-Friesian koeien bleek dat bij toenemende THI het celgetal toenam (Lambertz et al., 2014). Uit een data-analyse van de melksamenstelling van Italiaanse koeien over de periode 2003-2009 werd vanaf een THImax 57 een toename waar genomen in het celgetal, en vanaf een THImax 73 een toename in de bacteriële telling (Bertocchi et al., 2014).

De belangrijkste resultaten t.a.v. het celgetal zijn:

- Tijdens warme perioden is het tankmelkcelgetal het hoogst, waarbij er geen verschil bleek te zijn tussen bedrijven die onbeperkt weiden, beperkt weiden of jaarrond opstallen.

- Koeien met de hoogste dagelijkse melkproductie vertoonde de grootste stijging in celgetal tijdens warme perioden. 
- Oudere koeien en laat-lactatie koeien hadden de grootste kans op een verhoogd celgetal.

- In één studie is onderzoek gedaan naar de bacteriële telling in melk welke een stijging liet zien tijdens warme perioden.

\subsection{Effect op gezondheid}

Uit een data-analyse van 300 Nederlands melkveebedrijven over een periode van vier jaar (19921995) bleek er een seizoenseffect te zijn op de incidentie van klinische mastitis. De incidentie van klinische mastitis was het hoogst in de periode december-januari, behalve voor Streptococcus uberis die het hoogst was in Augustus. Een kleine piek in de incidentie van klinische mastitis was te zien in tweede helft van Juli, voor bij bedrijven met de hoogste tankmelkcelgetal, wat veroorzaakt door piek in klinische Staph. Aureus en E.coli mastitis. Jaarrond opgestalde koeien hadden een grotere kans op klinische E.coli mastitis in de zomer dan in de winter. Streptococcus uberis lijkt geassocieerd te zijn met weiden terwijl E.coli meer stal gerelateerd lijkt te zijn. Verder bleek dat in de eerste 14 dagen na afkalven de hoogste incidentie van klinische mastitis op te treden, waarna een sterke afdaling optreedt gevolgd door een geleidelijke afname, behalve voor meerkalfskoeien die eerst nog een stijging lieten zien voordat de daling inzette. Uit de analyse kwam ook naar voren dat de meeste koeien in de periode september-december afkalven en dan geleidelijk afneemt tot aan augustus waarna de afkalvingen weer toenemen (Olde Riekerink et al., 2007).

Uit onderzoek op een commercieel Italiaans melkveebedrijf bleek dat zomerse condities met middelmatige hittestress wijzen op het optreden van oxidatieve stress bij transitie koeien (Bernabucci et al., 2002). Uit een ander onderzoek op een commercieel Italiaans melkveebedrijf bleek dat bij transitiekoeien die in het voorjaar afkalfden de conditiescore pas na afkalven begon te dalen terwijl bij transitiekoeien die in zomer afkalfden de conditiescore ongeveer 15 dagen voor afkalven al begon te dalen. Er werd een sterk effect van de zomer op het vetmetabolisme gevonden. Bij de zomer afkalvende koeien werd een hogere vet accumulatie in de lever waargenomen wat de koeien gevoeliger maakt voor stofwisselingsziekten (Basiricò et al., 2009).

In een klein onderzoek met vier Jersey koeien in Nieuw-Zeeland is in twee klimaatkamers onderzocht wat het effect tussen $30^{\circ} \mathrm{C}$ en $15^{\circ} \mathrm{C}$ was op de rectale temperatuur, ademhalingsfrequentie en pens karakteristieken. De twee koeien bij $30^{\circ} \mathrm{C}$ hadden een significante hogere rectale temperatuur $(38,77$ vs. $37,64^{\circ} \mathrm{C}$ ) en hogere ademhalingsfrequentie (94 vs. 22 per min.). De pH van de pensvloeistof was op elk van de vier meetmomenten op een dag lager bij de $30^{\circ} \mathrm{C}$ dan bij $15^{\circ} \mathrm{C}$ koeien, maar alleen significant verschillend bij het meetmoment om 05:45. De pH nam bij beide groepen af gedurende de dag. Het gehalte aan azijnzuur in de pensvloeistof nam af gedurende de onderzoeksperiode bij de $30^{\circ} \mathrm{C}$ koeien, terwijl het toenam bij de $15^{\circ} \mathrm{C}$ koeien. De veranderingen in propionzuur en boterzuur waren klein en niet significant verschillend (Bandaranayaka en Holmes, 1976). In een proef met zes pensfistel koeien in klimaatkamers is onderzocht wat het effect is van rantsoen (hoog aandeel ruwvoer $(H R)$ vs. hoog aandeel graan (HG)) en temperatuur-luchtvochtigheid $(\mathrm{TL})\left(18,3^{\circ} \mathrm{C} \& \mathrm{RV} 50 \%\right.$ vs. $29,4^{\circ} \mathrm{C} \& \mathrm{RV} 85 \%$ ) op de pens $\mathrm{pH}$, oxidatie-reductie potentieel (ORP), ammonia (NH3) en melkzuur van lacterende koeien. De koeien kregen een volledig gemengd rantsoen. Bij de lage TL was pens $\mathrm{pH}$ hoger dan bij de hoge TL (ca 6,3 vs. 5,8). Bij het HR-rantsoen was de pens pH hoger dan bij het HGrantsoen (ca. 6,2 vs. 5,9). De hoogste pens $\mathrm{pH}($ ca. 6,5) werd gemeten bij de lage TL bij het HRrantsoen, terwijl de laagste pens $\mathrm{pH}(\mathrm{ca} .5,5)$ werd gemeten bij de hoge TL bij het HG-rantsoen. De ORP was bij de hoge TL negatiever dan bij de lage TL (ca. $-525 \mathrm{mV}$ vs. $-515 \mathrm{mV}$ ). En het HG-rantsoen had een negatievere ORP dan het HR-rantsoen (ca. $-505 \mathrm{mV}$ vs. $-535 \mathrm{mV}$ ). De gemiddelde ammoniakconcentratie in de pens was bij de hoge TL hoger dan bij de lage TL (ca. $31 \mathrm{vs.} 26 \mathrm{mg} \%$ ). De gemiddelde melkzuurconcentratie in de pens was bij de hoge TL hoger dan bij de lage TL (ca. 1,9 vs. 0,4 meq/l). De overige behandelingen waren niet significant verschillend (Mishra et al., 1970).

In een data-analyse over de periode 2002-2007 is onderzocht wat de relatie is tussen de THI en de sterfte onder Italiaanse koeien. Vanaf een THI van 70 werd een toename in sterfte gevonden. Over de zes-jaar durende onderzoeksperiode lag het gemiddelde sterftepercentage in de zomer op $0,85 \%$ en in het voorjaar op $0,62 \%$ (Vitali et al., 2009). In een andere data-analyse is het effect van hittegolven ( $\geq 3$ dagen) op de sterfte van Italiaanse melkkoeien over de periode 2002-2007 onderzocht. Het bleek 
dat de sterfte groter was tijdens een hittegolf vergeleken met dagen zonder hittegolf. Het risico op sterfte bleef verhoogd tot drie dagen na afloop van de hittegolf. Alleen bij koeien tot 28 maanden werd geen effect waargenomen. Het risico was het hoogst in de vroege zomermaanden, met name juni (Vitali et al., 2015).

Hoewel niet direct zichtbaar tijdens perioden van hittestress blijkt uit ervaringen van Engelse rundveeartsen dat er op langere termijn negatieve effecten zijn op de klauwgezondheid. Ongeveer 6 tot 10 weken na het optreden van hittestress wordt een toename waargenomen in klauwproblemen en een verslechtering in de locomotie score. Als oorzaak wordt genoemd dat melkkoeien tijdens hittestress meer staan om meer warmte kwijt te kunnen waardoor extra druk op de klauwen komt te staan en tijdens het staan vermindert de bloedcirculatie in de klauwen waardoor letsel minder snel herstelt, in het bijzonder als ze staan op betonnen roosters (Porter, 2014). Uit een analyse van de gegevens uit Digiklauw wordt jaarlijks in het derde kwartaal een toename van klauwaandoeningen gezien, en met name wittelijnproblemen (GD, 2018a). Ook Nederlandse dierenartsen ervaren na de zomerperiode meer klauwproblemen en meer salmonella (Hegen, 2018; Hooijer, 2018).

De belangrijkste resultaten t.a.v. gezondheid zijn:

- De incidentie van klinische mastitis was het hoogst in de periode december-januari, behalve voor Streptococcus uberis die het hoogst was in augustus. Een kleine piek in de incidentie van klinische mastitis was te zien in tweede helft van juli, voor bij bedrijven met de hoogste tankmelkcelgetal.

- Bij transitiekoeien blijkt in de zomer de conditiescore al voor het afkalven te dalen, terwijl dit in het voorjaar pas na het afkalven gebeurd. Tevens wijst één studie op het optreden van oxidatieve stress bij transitie koeien bij middelmatige hittestress.

- In één studie werd bij zomer afkalvende koeien een hogere vetaccumulatie in de lever waargenomen wat koeien gevoeliger maakt voor stofwisselingsziekten.

- De pH in de pens is lager bij hogere temperaturen. Ook bleek in één studie de ammoniakconcentratie en melkzuurconcentratie in de pens lager te zijn bij hogere temperaturen.

- Uit twee studies bleken er meer koeien te sterven onder zomerse condities.

- Na de zomer worden in de praktijk meer klauwproblemen waargenomen.

\subsection{Effect op vruchtbaarheid}

In Nedersaksen is onderzoek gedaan naar het effect van hittestress op het percentage drachtig geworden melkkoeien in drie verschillende regio's: kustregio gekarakteriseerd door weidebedrijven, inlands-regio gekarakteriseerd door weidebedrijven en een akkerbouw-regio gekarakteriseerd door bedrijven die opstallen. In alle regio's werd vanaf een drempelwaarde THI $=65$ een sterke afname in drachtig geworden koeien vastgesteld. De afname was het sterkst bij hoogproductieve melkkoeien in de regio waar koeien werden geweid (Brügemann et al., 2013). Op een Duits melkveebedrijf met 1.150 melkkoeien is in de periode mei $2010 \mathrm{t} / \mathrm{m}$ oktober 2012 onderzoek gedaan naar het effect van hittestress op het kengetal 'conception rate (CR)' van koeien. Koeien tijdens een kortdurende periode van hittestress ( $\mathrm{THI} \geq 73$ op de dag van bevruchting) hadden $37 \%$ minder kans om drachtig te worden, terwijl koeien tijdens een langdurige periode van hittestress ( $T H I \geq 73$ van dag 21 tot dag 1 voor bevruchting) $63 \%$ minder kans om drachtig te worden in vergelijking tot koeien die bevrucht waren tijdens een periode zonder hittestress. Koeien die kunstmatig waren geïnsemineerd bleken minder kans te hebben om drachtig te worden dan koeien die op natuurlijke wijze waren geïnsemineerd. Bij gebruik van bevroren sperma hadden koeien tijdens een periode van kortdurende hittestress $31 \%$ minder kans om drachtig te worden, terwijl koeien tijdens een periode van langdurige hittestress $61 \%$ minder kans dan in perioden zonder hittestress. Bij inseminatie met vers sperma was bij zowel een periode van kortdurende als een periode van langdurige hittestress $85 \%$ minder kans om drachtig te worden (Schüller et al., 2015). In een data-analyse van Italiaanse Holstein koeien van 484 bedrijven over de periode 2001-2007 is het effect van hittestress op het kengetal 'non return percentage op 56 dagen na de eerste inseminatie (NR56)' bepaald bij eerste, tweede en derde kalfskoeien. De NR56 werd zowel voor eerste als tweede kalfskoeien negatief beïnvloed door de THI van 4 dagen voor tot 5 dagen na de dag van inseminatie. De meest kritische periode blijkt 4 dagen voor de inseminatie te zijn. Bij $1^{\mathrm{e}}$ kalfskoeien gebeurde dit vanaf een gemiddelde THI van 73 (variatie $64-78$ ), terwijl bij de $2^{\mathrm{e}}$ kalfskoeien dit gebeurde vanaf een 75 (variatie 72-78). Ondanks de hogere THI bij $2^{\mathrm{e}}$ kalfskoeien 
hadden deze een grotere afname in het NR56 dan $1^{\mathrm{e}}$ kalfskoeien. Bij $3^{\mathrm{e}}$ kalfskoeien geen drempelwaarde kon worden vastgesteld. Voor de derde kalfkoeien nog niet worden vastgesteld vanaf welke THI een negatief effect optrad wat niet kon worden verklaard (Biffani et al., 2016). Ook Nederlandse dierenartsen ervaren na de zomerperiode slechtere vruchtbaarheid (Hegen, 2018; Hooijer, 2018).

De belangrijkste resultaten t.a.v. vruchtbaarheid zijn:

- Er is een negatief effect van hittestress op het drachtigheidspercentage, waarbij de afname het sterkst is bij hoogproductieve koeien. Het effect is groter bij langdurige periode van hittestress dan bij een kortdurende periode.

- In één onderzoek scoorde KI slechter dan natuurlijke dekking en scoorde vers sperma beduidend slechter dan bevroren sperma.

\subsection{Effect op gedrag}

Uit Nederlands onderzoek eind jaren '90 bleek dat koeien die worden gemolken door een Automatisch Melksysteem (AMS) tijdens warme perioden overdag meer tijd in de stal doorbrachten dan bij normale temperaturen. Melkkoeien waren minder in de wei tussen 10 en 17 uur als de zwarte bol temperatuur luchtvochtigheidsindex (BGHI) hoog was (Ketelaar-De Lauwere et al., 1999). Ook uit Zweeds onderzoek bleek dat bij een AMS de melkkoeien overdag minder tijd in de wei doorbrachten bij een $\mathrm{THI}>72$, maar daarentegen waren meer koeien in de wei gedurende de nacht waardoor in totaal meer tijd in de wei werd doorgebracht bij een THI>72 (Nielsen en Wredle, 2016). De voorkeur van koeien bij een vrije keuze tussen stal of wei blijkt niet eenduidig te zijn. In een Engels onderzoek brachten de koeien steeds meer tijd door in de wei bij een stijgende THI over de THI-range van 45 tot 65 (Charlton et al., 2011a), terwijl in Canadees onderzoek de koeien bij een toename in THI over de THIrange van 52 tot 78 juist steeds meer tijd doorbrachten in de stal (Legrand et al., 2009). Bij het Engelse onderzoek waren de koeien grotendeels in de wei opgefokt, konden de koeien zowel in de stal als in de wei het aanvullende TMR-rantsoen opnemen en was de hoogste THI beduidend lager dan bij het Canadese onderzoek. Uit Amerikaans onderzoek in een ligboxenstal bij opgestalde koeien bij een THI-range van 56 tot 74 bleek dat de ligtijd van de koeien afnam. Tijdens de koelste periode was de ligtijd 10,9 uur/dag en bij de heetste periode 7,9 uur/dag. Deze gedragsverandering vond met name plaatst tussen 06:00 en 18:00. De sta-tijd nam toe van 2,6 uur/dag in de koelste periode naar 4,5 uur/dag in de warmste periode, waarbij met name tussen 12:00 en 18:00 de verandering in sta-tijd optrad. De veranderingen in gedrag traden op rond een THI van 68 (Cook et al., 2007).

De belangrijkste resultaten t.a.v. gedrag zijn:

- Bij koeien die werden gemolken met een automatisch melksysteem (AMS) bleken tijdens warme perioden overdag meer tijd door te brengen in de stal, en 's nachts meer tijd in de wei.

- De voorkeur van koeien voor wei of stal blijkt niet altijd eenduidig te zijn met een toenemende THI, aangezien verschillende onderzoeken verschillende resultaten laten zien waarbij bedrijfsopzet en management van invloed lijken te zijn.

- Uit één studie bij jaarrond opgestalde koeien bleken koeien bij een toenemende THI meer te gaan staan en minder te gaan liggen.

\subsection{Effect op voer- en wateropname}

Uit onderzoek in Nedersaksen bleek dat bij een THI>60 de voeropname afnam van melkkoeien, terwijl de wateropname lineair toe nam vanaf een THI>35 (Gorniak et al., 2014). Uit Schots onderzoek van een melkveebedrijf over de periode 2004-2011 kwam naar voren dat de voeropname en -efficiëntie van een totaal gemengd (TMR) rantsoen varieerde als gevolg van het weer. Bij een hogere THI nam de droge stof opname af, maar nam de voerefficiëntie toe. De toename in voerefficiëntie was sterker voor koeien met een hoge genetische aanleg voor melkkarakteristieken. De droge stof opname was het hoogst bij een THI van 39 voor zowel koeien met een hoge genetische aanleg voor melkkarakteristieken als gemiddelde koeien. Tussen THI 55 en 65 nam de droge stof opname lineair af 
met $80 \mathrm{~g}$ voor 1 eenheid toename in THI. Bij THI 65 lag de droge stof opname 5,3\% lager voor de hoge genetische aanleg en 5,9\% lager voor gemiddelde koeien t.o.v. de opname bij een THI van 39. Bij een THI van 74 lag de opname respectievelijk 11,5\% en 12,8\% lager (Hill en Wall, 2017). In een Duits onderzoek is bij zeven $2^{\mathrm{e}}$ kalfs Holstein koeien in de late droogstand en vroege lactatie in klimaatkamers onderzocht wat het effect van een verhoogde THI is op de dynamiek van de droge stof opname. $\mathrm{Er}$ is een vergelijking gemaakt tussen een $\mathrm{THI}$ van $60\left(\mathrm{~T}=15^{\circ} \mathrm{C}, \mathrm{RV}=63 \%\right)$ en een $\mathrm{THI}$ van 76 $\left(\mathrm{T}=28^{\circ} \mathrm{C}, \mathrm{RV}=52 \%\right)$. Zowel in de late droogstand (10,2 vs. 5,5 kg DS/dag) als vroege lactatie $(15,5$ vs. 9,3 kg DS/dag) was de droge stof opname verlaagd. In de late droogstand verlaagde de opname door een afname in maaltijdgrootte (0,7 vs. 0,4 kg DS/maaltijd), afname in duur van een maaltijd ( 31,0 vs. $23,8 \mathrm{~min} / \mathrm{maaltijd}$ ), en afname in eetsnelheid (0,023 vs. 0,017 kg DS/min.) en dagelijkse vreettijd (432,1 vs. 343,7 min/dag), maar er was geen verandering in maaltijdfrequentie of interval tussen maaltijd. Bij de koeien in de vroege lactatie werd geen eenduidig beeld vastgesteld, maar varieerde de verandering in eetgedrag van de koeien. De koeien bij een hoge THI aan het begin van de lactatie hadden een lagere vetoxidatie na een maaltijd, langere voervertering en dus een verschuiving van vet naar glucose benutting (Eslamizad et al., 2015). In een ander onderzoek met vergelijkbare THI's in klimaatkamers met 14 Duitse Holstein transitie koeien vond een metabolische verschuiving plaats naar meer koolhydraat oxidatie. Bij een hoge THI werd uitgebreid eiwitweefsel afgebroken om in de koolhydratenbehoefte te kunnen voorzien. De metabolische reactie verschilde tussen late droogstand koeien en koeien in de vroege lactatie (Lamp et al., 2015).

Uit Italiaans onderzoek bij het voeren van een totaal gemengd rantsoen aan koeien zonder weidegang bleek het voermanagement van invloed te zijn op de ademhalingsfrequentie en rectale temperatuur van mid-lactatie melkkoeien tijdens perioden van milde tot hoge hittestress. Tijdens warme dagen was bij alleen 's ochtends voeren de ademhalingsfrequentie $(71,4)$ en rectale temperatuur $\left(39,0^{\circ} \mathrm{C}\right)$ hoger dan bij 's ochtends en 's avonds $\left(66,5 ; 38,7^{\circ} \mathrm{C}\right)$ of bij alleen 's avonds voeren $\left(65,3 ; 38,6^{\circ} \mathrm{C}\right)$. Bij alleen 's ochtends voeren was er een meer uitgesproken verandering van bloedvariabelen gerelateerd aan energiemetabolisme, met een verslechtering van de energiebalans. Bloedvariabelen gerelateerd aan eiwitmetabolisme hadden lagere waarden bij melkkoeien die alleen 's avonds voer kregen. Het voermanagement had geen effect op de melkproductie en melkkarakteristieken (Calamari et al., 2013).

De belangrijkste resultaten t.a.v. voer- en wateropname zijn:

- Vanaf een THI van circa 55-60 begint een afname in droge stof opname op te treden.

- In één studie met gegevens van melkkoeien over een periode 8 jaar werd bij een THI van 65 een circa $6 \%$ lagere droge stof opname gevonden en bij een THI van 74 een daling van circa $12 \%$.

- In één studie bij droge koeien in de late droogstand werd bij een THI van 76 een afname van $46 \%$ in droge stof opname gemeten, en bij koeien in de vroege lactatie een afname van $40 \%$.

- Vanaf een THI van 76 zijn metabolische verschuivingen van vet naar koolhydraten benutting vastgesteld.

- Er treedt een verandering op in eetgedrag door aanpassing van maaltijdgrootte, maaltijdduur en eetsnelheid.

- Het voermanagement blijkt van invloed te zijn op de ademhalingsfrequentie en rectale temperatuur.

- De wateropname neemt toe. In één studie bleek de wateropname lineair toe te nemen vanaf een THI van 35.

\subsection{Effect van schaduwverstrekking}

\section{Melkproductie en -samenstelling}

Uit Nieuw-Zeelands onderzoek bleek dat ondanks milde temperaturen met een gemiddelde maximale temperatuur van $25,2^{\circ} \mathrm{C}$ schaduwverstrekking in de wei leidde tot een $3 \%$ hogere melkproductie $(17,7$ vs. $17,2 \mathrm{~kg} \mathrm{melk} / \mathrm{dag}$ ), maar de melksamenstelling bleek niet te verschillen (Kendall et al., 2006). In een andere Nieuw-Zeelandse studie werd ook een 3\% hogere melkproductie en geen effect op melksamenstelling gevonden bij koeien die de beschikking hadden over schaduwdoek tijdens temperaturen boven de $25^{\circ} \mathrm{C}$ (Fisher et al., 2008). Ook in Belgisch onderzoek leverde 
schaduwverstrekking een hogere melkproductie op. Bij koeien die geen toegang tot schaduw hadden was de melkgift licht verminderd (tot 1 liter/dag per koe), terwijl bij koeien met toegang tot schaduw geen sprake was van daling in de melkgift (Van Laer et al., 2015b). Daarentegen werd onder Canadese omstandigheden geen verschil in melkproductie gevonden als melkkoeien toegang hadden tot een verplaatsbare schaduwconstructie (Palacio et al., 2015). Mogelijk dat geen verschil werd gevonden doordat alleen midden op de dag (11:30 tot 15:30) de THI boven de thermoneutrale comfortzone uit kwam, terwijl de gemiddelde 24-uurs THI onder de 72 bleef waardoor de koeien in de overige uren voldoende tijd hadden om eventuele negatieve effecten op de melkproductie te compenseren.

Uit Australisch onderzoek blijkt dat bij weidegang met een melkrobot zonder overdekte wachtruimte schaduwverstrekking boven de wachtruimte leidde tot een hogere melkproductie $(11,44 \mathrm{vs} .10,95 \mathrm{~kg}$ melk/koe per melkbeurt $\Rightarrow+4,5 \%$ ) (Wildridge et al., 2017). Uit Argentijns onderzoek bleken sprinklers i.c.m. ventilatoren in de wachtruimte voor de melkstal bij milde zomertemperaturen $\left(23,5^{\circ} \mathrm{C}\right)$ te leiden tot een hogere melkproductie bij koeien (1,04 liter/koe per dag) die 's nachts werden geweid en overdag in een "pen" met schaduw verbleven (Valtorta en Gallardo, 2004).

De belangrijkste resultaten t.a.v. schaduwverstrekking op de melkproductie en -samenstelling zijn:

- Schaduwverstrekking leidt tot een betere melkproductie, waarbij stijgingen tot $5 \%$ zijn gerapporteerd.

- Op basis van één studie lijkt schaduwverstrekking niet van invloed te zijn op de melksamenstelling.

\section{Gezondheid: lichaamstemperatuur en ademhalingsfrequentie}

Uit Nieuw-Zeelands onderzoek bleek dat, ondanks milde temperaturen met een gemiddelde maximale temperatuur van $25,2^{\circ} \mathrm{C}$, schaduwverstrekking aan mid-lactatie koeien de gemiddelde vaginale temperatuur significant reduceerde. Dit was met name duidelijk zichtbaar tussen 10:00 en 15:00 waarin de toename in vaginale temperatuur significant lager was bij de koeien met toegang tot schaduw. Verstrekking van schaduw gaf een significant lagere gemiddelde vaginale temperatuur $\left(38,6^{\circ} \mathrm{C}\right.$ vs. $\left.38,7^{\circ} \mathrm{C}\right)$, maar er was geen verschil tussen de gemiddelde maximale en minimale vaginale temperatuur op een dag. De hoogste gemiddelde vaginale temperatuur werd gemeten tussen 17:2017:30, circa 110 minuten na de piek in THI. De minimale vaginale temperatuur werd gemeten tussen 7:10 en 7:20 (Kendall et al., 2006). Daarentegen werd onder Canadese omstandigheden geen verschil in gemiddelde 24-uurs vaginale temperatuur gevonden als melkkoeien toegang hadden tot een verplaatsbare schaduwconstructie $\left(38,6^{\circ} \mathrm{C}\right.$ vs. $\left.38,6^{\circ} \mathrm{C}\right)$. De gemiddelde vaginale temperatuur tijdens piekuren bedroeg $39,1^{\circ} \mathrm{C}$ zonder schaduw en $38,9^{\circ} \mathrm{C}$ bij schaduwverstrekking (Palacio et al., 2015), wat mogelijk werd veroorzaakt doordat alleen midden op de dag (11:30 tot 15:30) de THI boven de thermoneutrale comfortzone uit kwam, terwijl de gemiddelde 24-uurs THI onder de 72 bleef waardoor de koeien in de overige uren voldoende tijd hadden om eventuele negatieve effecten op de lichaamstemperatuur te compenseren. Schaduwdoeken met een hoger percentage blokkering van de zonnestraling leidden niet tot een significant lagere gemiddelde 24 -uurs lichaamstemperatuur $\left(38,6^{\circ} \mathrm{C}\right.$ vs. $\left.38,5^{\circ} \mathrm{C}\right)$ of lagere maximale lichaamstemperatuur $\left(39,5^{\circ} \mathrm{C}\right.$ vs. $\left.39,5^{\circ} \mathrm{C}\right)$, maar wel tot een significant lagere minimale lichaamstemperatuur $\left(37,9^{\circ} \mathrm{C}\right.$ vs. $\left.37,7^{\circ} \mathrm{C}\right)$ bij geen schaduw en bij $99 \%$ zonblokkering (Tucker et al., 2008). Ook het verstrekken van schaduwplekken op het kavelpad van de wei naar een melkrobot blijkt te leiden tot een lagere lichaamstemperatuur $\left(38,8^{\circ} \mathrm{C}\right.$ vs. $39,0^{\circ} \mathrm{C}$ ) (Wildridge et al., 2016). Uit Argentijns onderzoek bleken sprinklers i.c.m. ventilatoren in de wachtruimte voor de melkstal bij milde zomertemperaturen $\left(23,5^{\circ} \mathrm{C}\right)$ te leiden tot een $0,3^{\circ} \mathrm{C}$ lagere gemiddelde rectale temperatuur (39,6 vs. 39,3) na de middagmelking om 17:00 bij koeien die 's nachts werden geweid en overdag in een "pen" met schaduw verbleven (Valtorta en Gallardo, 2004).

Het verstrekken van schaduw blijkt te leiden tot een lagere ademfrequentie. Op zes commerciële Nieuw-Zeelandse melkveebedrijven bleek over een periode van twee zomermaanden dat wanneer koeien schaduwmogelijkheden (bomen, struiken, etc.) tot hun beschikking hadden ze een lagere ademhalingsfrequentie hebben dan koeien zonder natuurlijke schaduw (Schütz et al., 2014). In België bleef bij warme condities (zwarte bol temperatuur $\geq 30$ ) bij meer dan $50 \%$ van de melkkoeien met schaduw de ademhalingsfrequentie onder de 90 ademhalingen per minuut, terwijl dit bij de melkkoeien zonder schaduw aanzienlijk lager was (Van Laer et al., 2015a). De hoeveelheid schaduw per koe blijkt ook van invloed te zijn op de ademhalingsfrequentie. De ademhalingsfrequentie is hoger 
naarmate minder schaduw beschikbaar was: 62 ademhaling/min bij geen schaduw, 57 bij 2,4 $\mathrm{m}^{2}$ schaduw/koe en 51 bij 9,6 m²/koe (Schütz et al., 2010). Het verstrekken van schaduwplekken op het kavelpad van de wei naar een melkrobot blijkt te leiden tot een lagere ademhalingsfrequentie (Wildridge et al., 2016). Het uitrusten van de wachtruimte voor een melkstal met schaduw bleek de ademhalingsfrequentie bij melkkoeien die geweid worden met $30 \%$ te verlagen naar 54 ademhalingen per minuut, uitrusten met sprinklers met $60 \%$ te verlagen en de combinatie schaduw met sprinklers met $67 \%$ te verlagen. Bij toepassing van schaduw en/of sprinklers was de lichaamstemperatuur 0,2 tot $0,3^{\circ} \mathrm{C}$ lager dan de $38,9 \circ \mathrm{C}$ van de controlegroep. Het effect van de lagere lichaamstemperatuur bij de sprinklers duurde tot minstens 4 uur na het melken (Kendall et al., 2007). Ook bij weidegang met een melkrobot zonder overdekte wachtruimte blijkt schaduwverstrekking boven de wachtruimte te leiden tot een lagere ademhalingsfrequentie (68 vs. 73 ademhalingen/min) (Wildridge et al., 2017). Uit Argentijns onderzoek bleken sprinklers i.c.m. ventilatoren in de wachtruimte voor de melkstal bij milde zomertemperaturen $\left(23,5^{\circ} \mathrm{C}\right)$ te leiden tot een $24 \%$ lagere ademhalingsfrequentie bij koeien die 's nachts werden geweid en overdag in een "pen" met schaduw verbleven (Valtorta en Gallardo, 2004).

Schaduwverstrekking leidt ook tot een lagere panting score. Op zes commerciële Nieuw-Zeelandse melkveebedrijven bleek over een periode van twee zomermaanden dat een groter deel van de kudde panting scores $\geq 2$ had wanneer er geen schaduwmogelijkheden (bomen, struiken, etc.) aanwezig waren. Koeien met toegang tot schaduw hadden lagere panting scores. Als er meer schaduw beschikbaar was dan maakte een groter aandeel van de koeien daar gebruik van en namen de panting scores af (Schütz et al., 2014). Ook in Belgisch onderzoek leverde schaduwverstrekking een lagere panting score op. Bij warme condities (zwarte bol temperatuur $\geq 30$ ) bleef bij meer dan $50 \%$ van de melkkoeien met schaduw de panting score normaal $(<1)$, terwijl het aandeel bij de melkkoeien zonder schaduw aanzienlijk lager was (Van Laer et al., 2015a; Van Laer et al., 2015b).

De belangrijkste resultaten t.a.v. schaduwverstrekking op de gezondheid zijn:

- Schaduwverstrekking leidt tot lagere lichaams- en vaginale temperatuur, verlaging tot $0,3^{\circ} \mathrm{C}$.

- Schaduwverstrekking leidt tot lagere ademhalingsfrequentie, verlaging tot $30 \%$.

- Schaduwverstrekking leidt tot een betere panting score.

\section{Gedrag}

Uit Nieuw-Zeelands onderzoek bleek ondanks milde temperaturen met een gemiddelde maximale temperatuur van $25,2^{\circ} \mathrm{C}$ dat mid-lactatie koeien goed gebruik maken van kunstmatige schaduw in de wei. Koeien maakten er voornamelijk gebruik van in de voormiddag. Er werden geen significante verschillen gevonden in de totale graastijd (8,9 vs. 9,2 uur/dag), ligtijd (8,3 vs. 8,4 uur/dag) en staan zonder te grazen ( 4,1 vs. 3,7 uur/dag) tussen koeien die wel toegang tot schaduw hadden in vergelijking tot de koeien die geen schaduwmogelijkheid hadden (Kendall et al., 2006). Ook Fisher et al. (2008) vonden geen verschil in graas-, sta- en ligtijd ondanks dat koeien met toegang tot schaduwdoek daar gemiddeld 80 minuten per dag onder verbleven. Koeien met toegang tot schaduw bleken tussen 00:00 en 03:30 meer te grazen. Onderzoek van Tucker et al. (2008) gaf vergelijkbare resultaten te zien. Als de gemiddelde zonnestraling toenam, dan nam het gebruik van de schaduw toe. Koeien waren meer geneigd gebruik te maken van schaduw wanneer de zonnestraling het hoogst was tijdens de dag. Er werd geen effect waargenomen op het lig- of graasgedrag. Koeien bleken ook meer gebruik te maken van schaduwdoeken als deze een hoger percentage zonnestraling blokkeerden. Ook in België nam bij een toenemende warmtebelastingsindex (Heat Load Index HLI) het gebruik van schaduw toe (Van Laer et al., 2015a; Van Laer et al., 2015b).

Daarentegen laten andere onderzoeken wel verschillen zien in gedrag bij schaduwverstrekking. Zo hebben (Schütz et al., 2010) onderzoek gedaan naar de invloed van de hoeveelheid schaduw op het gedrag van melkkoeien. Bij een toenemende warmtebelasting verbleven de koeien langer onder de aanwezige schaduwdoeken en minder tijd aan liggen. De tijd die werd gespendeerd bij de waterbak nam toe naarmate weinig of geen schaduw werd verstrekt. En er waren meer agressieve interacties als er onvoldoende schaduw beschikbaar was. Uit onderzoek op zes commerciële Nieuw-Zeelandse melkveebedrijven over een periode van twee zomermaanden bleek dat wanneer koeien schaduwmogelijkheden (bomen, struiken, etc.) tot hun beschikking hebben ze er ook gebruik van maken. Gemiddeld verbleven ze 31\% van de tijd tussen 10:00 en 15:00 in de schaduw. Koeien zonder 
toegang tot schaduw spendeerden $4 \%$ meer aan liggen. Het aandeel van de koeien dat gebruik maakte van de schaduw nam toe naarmate er meer schaduw was (Schütz et al., 2014). Ook onder Canadese omstandigheden bleken verschillen te zijn bij melkkoeien die toegang hadden tot een verplaatsbare schaduwconstructie. Ze lagen meer, toonden meer graasgedrag en spendeerden minder tijd bij de waterbak. De verschillen werden groter tussen koeien met wel en geen schaduw als de THI boven de comfortzone uitkwam over een periode van 24 uur (Palacio et al., 2015). Ook het verstrekken van schaduwplekken op het kavelpad van de wei naar een melkrobot blijkt te leiden tot verschillen in graas- en herkauwgedrag (Wildridge et al., 2016). Verder blijkt bij een melkrobot zonder overdekte wachtruimte dat schaduwverstrekking boven de wachtruimte leidt tot verschillen in gedrag. Bij schaduw verbleven de koeien langer in de wachtruimte voor de melkrobot, maar bleven minder lang wachten in de ruimte na de melkrobot, waarbij het verschil in totale wachttijd klein lijkt te zijn (Wildridge et al., 2017).

Resultaten van Nieuw-Zeelands onderzoek suggereren dat de behoefte aan schaduw tijdens warme dagen relatief hoog is, omdat melkkoeien er voor kozen om te gaan staan in de schaduw bij hoge temperaturen dan te gaan liggen op een plek zonder schaduw nadat ze 12 uur niet hadden kunnen liggen (Schütz et al., 2008). Daarnaast blijkt dat koeien de voorkeur geven aan schaduw boven sprinklers. De voorkeur voor schaduw nam toe met luchttemperatuur, zonnestraling en windsnelheid, ondanks dat sprinklers de ademhalingsfrequentie en insectenontwijkend gedrag meer verlaagden (Schütz et al., 2011).

De belangrijkste resultaten t.a.v. schaduwverstrekking op het gedrag zijn:

- Koeien maken gebruiken van kunstmatige schaduw als ze dat wordt aangeboden.

- Bij toenemende warmtebelasting neemt het gebruik van schaduw toe.

- Er worden verschillen in gedrag waargenomen, maar de resultaten zijn niet altijd significant.

- Er wordt minder tijd gespendeerd bij de waterbak.

- Koeien blijken voor een voorkeur te hebben voor schaduw boven sprinklers.

- Koeien blijken bij hoge temperaturen staan in de schaduw te verkiezen boven liggen op een plek zonder schaduw.

\section{Voer- en wateropname}

Uit Australisch onderzoek blijkt dat bij weidegang met een melkrobot zonder overdekte wachtruimte schaduwverstrekking boven de wachtruimte leidde tot een hogere opname van krachtvoer (6,5 vs. 6,4 $\mathrm{kg} / \mathrm{koe}$ ) (Wildridge et al., 2017). Uit Canadees onderzoek kwam naar voren dat koeien, die toegang hadden tot een verplaatsbare schaduwconstructie, tot 6,4 keer minder vaak bij de waterbak kwamen gedurende een periode waarin de THI boven de 72 uitkwam in vergelijking met koeien die geen toegang tot schaduw hadden (Palacio et al., 2015). In Nieuw-Zeeland werd in een onderzoek een significant verschil gevonden in de tijd die werd doorgebracht binnen een bereik van 4,5 meter van de waterbak tussen melkkoeien zonder toegang tot schaduw (11\%) en koeien met 9,6 $\mathrm{m}^{2}$ schaduw per koe (2\%) (Schütz et al., 2010). Maar in een ander onderzoek werd geen significant verschil gevonden in de verblijftijd binnen een bereik van 10 meter van de waterbak tussen melkkoeien zonder toegang tot schaduw of koeien met toegang tot schaduw $\left(0,9\right.$ tot $15,6 \mathrm{~m}^{2}$ schaduw per koe) (Schütz et al., 2014).

De belangrijkste resultaten t.a.v. schaduwverstrekking op de voer- en wateropname zijn:

- De opname van krachtvoer neemt toe.

- In het algemeen wordt geconstateerd dat er minder tijd wordt doorgebracht bij de waterbak.

\subsection{Monitoring tools}

De data die wordt verzameld door koesensoren kunnen mogelijk ook worden gebruikt om een earlywarning-system op te zetten voor het optreden van hittestress zodat de veehouder tijdig en adequaat maatregelen kan nemen om de negatieve gevolgen van hittestress te verminderen. Zo is door Abeni en Galli (2017) onderzoek gedaan naar het gebruik van koe-activiteit en herkauwtijd als een vroegtijdige waarschuwing voor hittestress. Bij een toenemende THI werd een toename in de totale dagelijkse activiteits-index en de overdag activiteits-index gevonden, en een afname in de totale 
dagelijks herkauwtijd, de overdag en de nacht herkauwtijd. Als oorzaak van de toename van de activiteits-index werd verondersteld dat de nek van de koe vaker beweegt wanneer temperatuur en THI toenemen aangezien de sensoren aan de nek waren bevestigd. Aanvullende waarnemingen zijn nodig onder verschillende omstandigheden (verschillen in koerassen en management) om drempelwaarden te kunnen vaststellen voor het geven van waarschuwingen aan de veehouder. Naast het gebruik van koesensoren kan men ook gebruik maken van een dynamisch lineair model voor tijdserie analyses van de dagelijkse melkproductie i.c.m. de dagelijkse buitentemperatuur van het dichtstbijzijnde weerstation om per koe de effecten van hittestress te bepalen waarmee het ingezet kan worden als monitoring tool voor het optreden van hittestress (André et al., 2011).

De belangrijkste resultaten t.a.v. monitoring tools zijn:

- Koesensoren kunnen worden gebruikt om vroegtijdige meldingen te geven van het optreden van hittestress. 


\section{$3 \quad$ Klimaat in Nederland}

\subsection{Huidig klimaat in Nederland}

In figuur 4 wordt het aantal warme, zomerse en tropische dagen weergegeven voor heel Nederland.
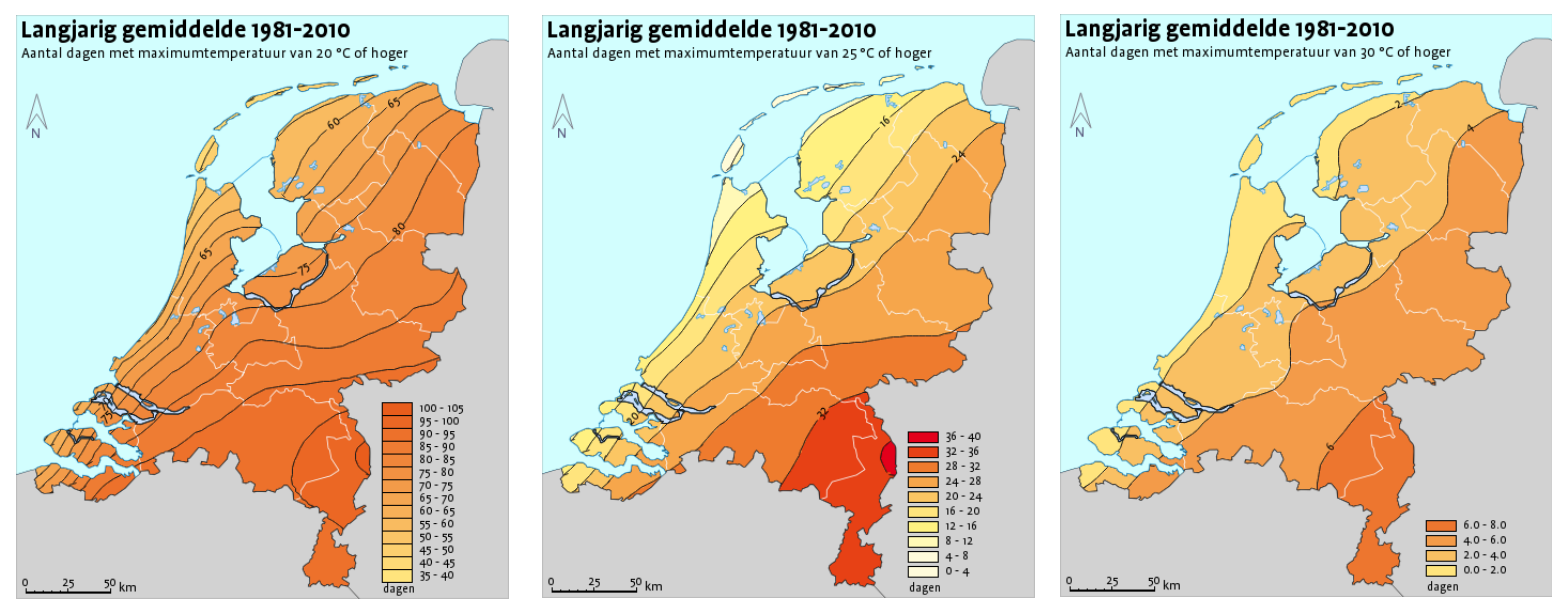

Figuur 4 Langjarig gemiddeld over de periode 1981-2010 van het aantal warme, zomerse en tropische dagen in Nederland waarbij de maximumtemperatuur respectievelijk boven de $20^{\circ} \mathrm{C}, 25^{\circ} \mathrm{C}$ en $30^{\circ} \mathrm{C}$ ligt (KNMI, 2018).

De variatie is groot in het aantal warme, zomerse en tropische dagen. Zo varieert het aantal warme dagen van circa 55 tot 100 warme dagen en het aantal zomerse dagen van circa 12 tot 32 dagen. Het aantal tropische dagen is beperkt in Nederland van 0 tot 8 . De locatie in Nederland is bepalend voor het aantal warme dagen wat een gevolg is van het lokale klimaat op een specifieke locatie. De kustregio's hebben met circa 55 à 65 het minst aantal warme dagen en hoe verder landinwaarts en hoe zuidelijker hoe men komt des te meer neemt het aantal toe tot aan circa 95 à 105 warme dagen in Oost-Brabant en Noord-Limburg. Dit komt neer op respectievelijk rond de $16 \%$ en $27 \%$ van de dagen in deze gebieden waarop de temperatuur boven de $20^{\circ} \mathrm{C}$ uitkomt. De risicomaanden zijn met name juli en augustus waarbij de gemiddelde maandtemperatuur het hoogst is (zie bijlage 1). Als ook de gemiddelde maximumtemperatuur in ogenschouw wordt genomen dan kan juni ook als een risicomaand worden beschouwd (zie figuur 5). In mei en september liggen de gemiddelde maximumtemperatuur in grote delen van Nederland nog boven de $18^{\circ} \mathrm{C}$ (zie bijlage 1 ) en geven daarom ook nog kans op negatieve effecten als gevolg van hittestress tijdens warme, zonnige dagen.
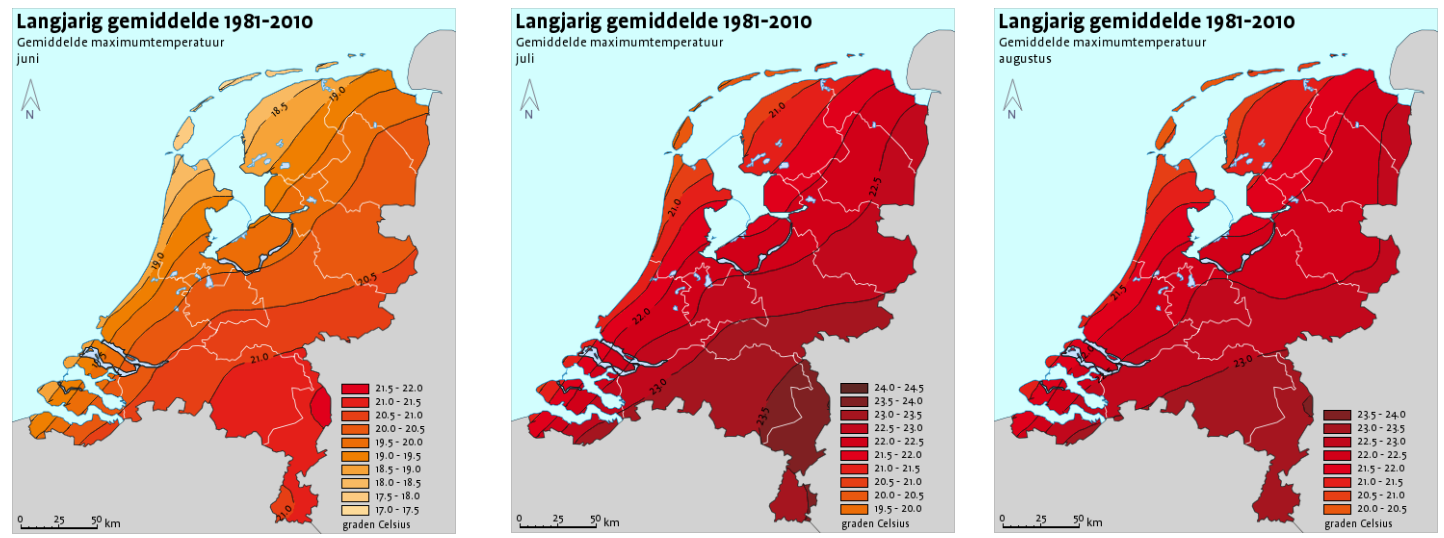

Figuur 5 Langjarig gemiddeld over de periode 1981-2010 van de gemiddelde maximumtemperatuur in juni, juli en augustus ligt (KNMI, 2018). 
Naast de temperatuur speelt ook de zonnestraling een belangrijke rol in welke mate hittestress optreedt bij dieren. In figuur 6 wordt het aantal dagen met af en toe zon, zonnig en zeer zonnig weer weergegeven voor heel Nederland.
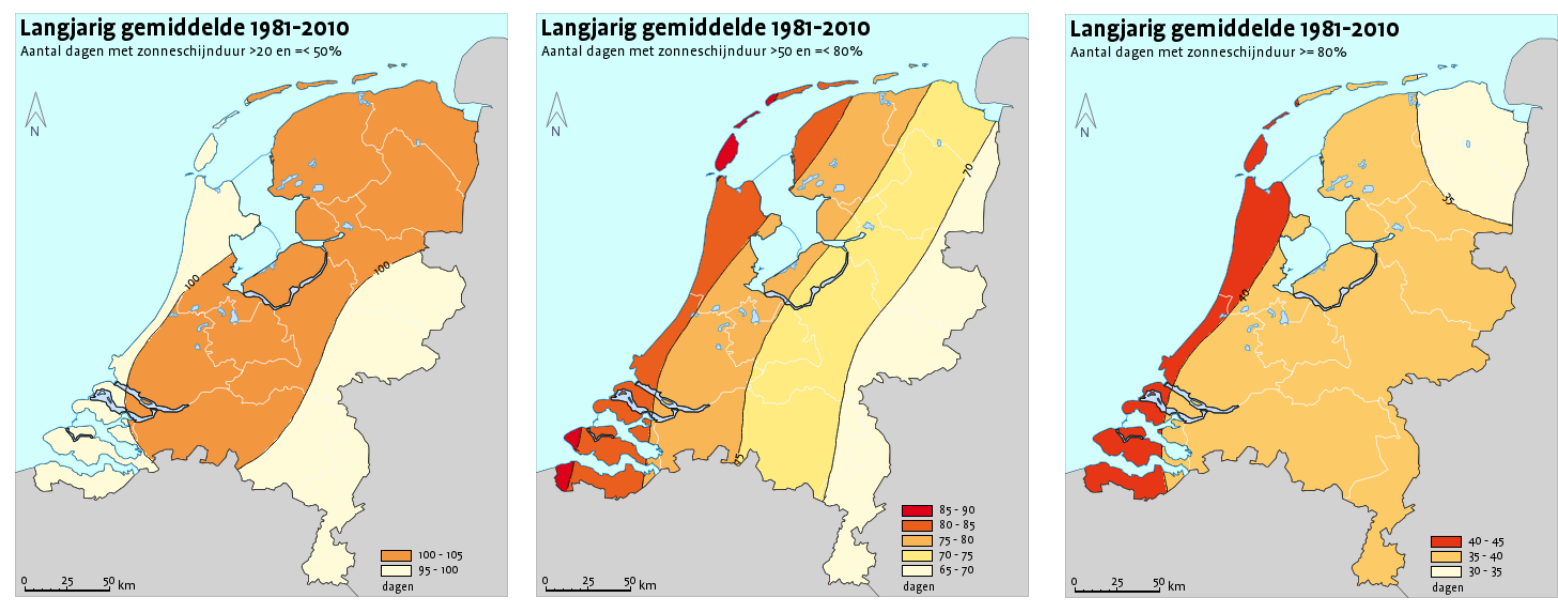

Figur 6 Langjarig gemiddeld aantal dagen met af en toe zon (20-50\%), zonnig (50-80\%) en zeer zonnig weer (>80\%) in Nederland (KNMI, 2018).

Ook bij het aantal dagen met zonnig en zeer zonnig weer is de variatie groot. Zo varieert het aantal zonnige dagen van circa 65 tot 90 en het aantal dagen met zeer zonnig weer van circa 30 tot 45 . Net zoals bij temperatuur is de locatie bepalend voor het aantal zonnige dagen, echter qua locatie heeft het aantal zonnige dagen een tegengesteld effect met het aantal warme, zomers en tropische dagen. Het aantal zonnige en zeer zonnige dagen is het hoogst aan de kust en neemt landinwaarts af.

Naast de temperatuur en zonnestraling speelt ook wind een rol in welke mate hittestress optreedt bij melkkoeien. In figuur 7 wordt de langjarig gemiddelde windsnelheid in de maanden april, augustus en december weer weergegeven voor heel Nederland. In bijlage 1 staan de overige maanden weergegeven.
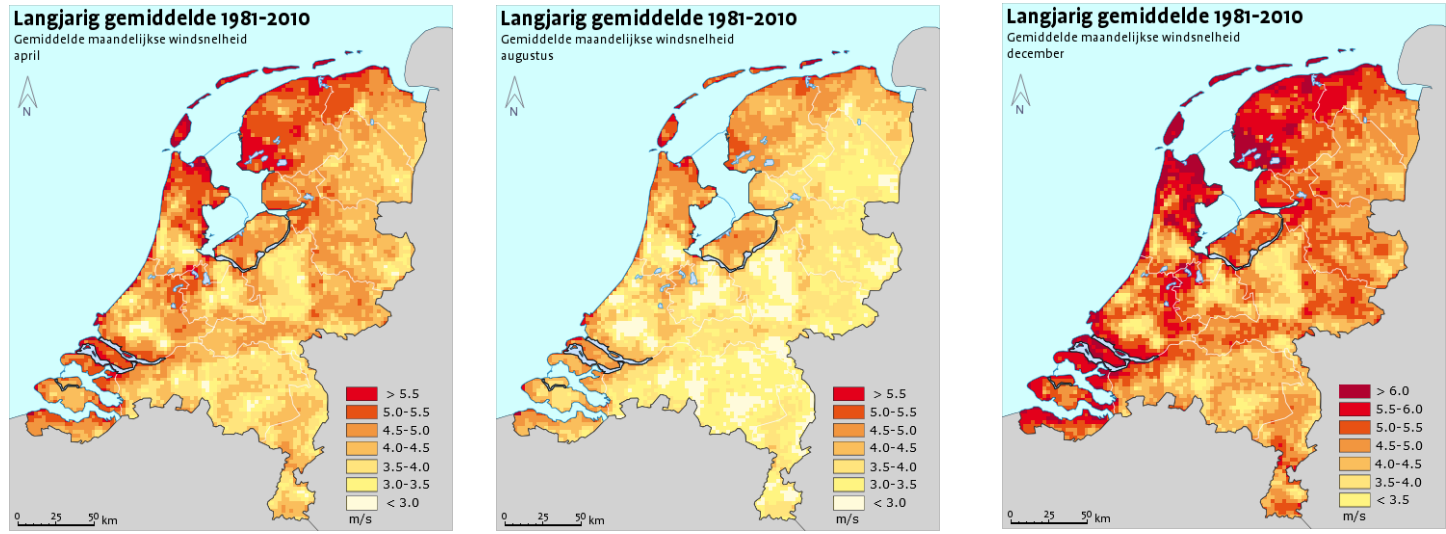

Figur 7 Langjarig gemiddelde maandelijkse windsnelheid in de maanden april, augustus en december in Nederland (KNMI, 2018).

De windsnelheden liggen het hoogst in de kustregio's en nemen landinwaarts af. Daarbij zijn tijdens de risicomaanden van hittestress de windsnelheden op het laagste niveau in het jaar, waardoor een verkoelend effect van de wind ook het laagst is in deze maanden.

Verder speelt naast temperatuur, zonnestraling en windsnelheid ook de relatieve luchtvochtigheid een rol. In figuur 8 wordt de langjarig gemiddelde relatieve luchtvochtigheid in de lente, zomer en herfst weer weergegeven voor heel Nederland. En in figuur 9 wordt de langjarig gemiddelde relatieve luchtvochtigheid in de lente, zomer en herfst weer weergegeven voor heel Nederland. 

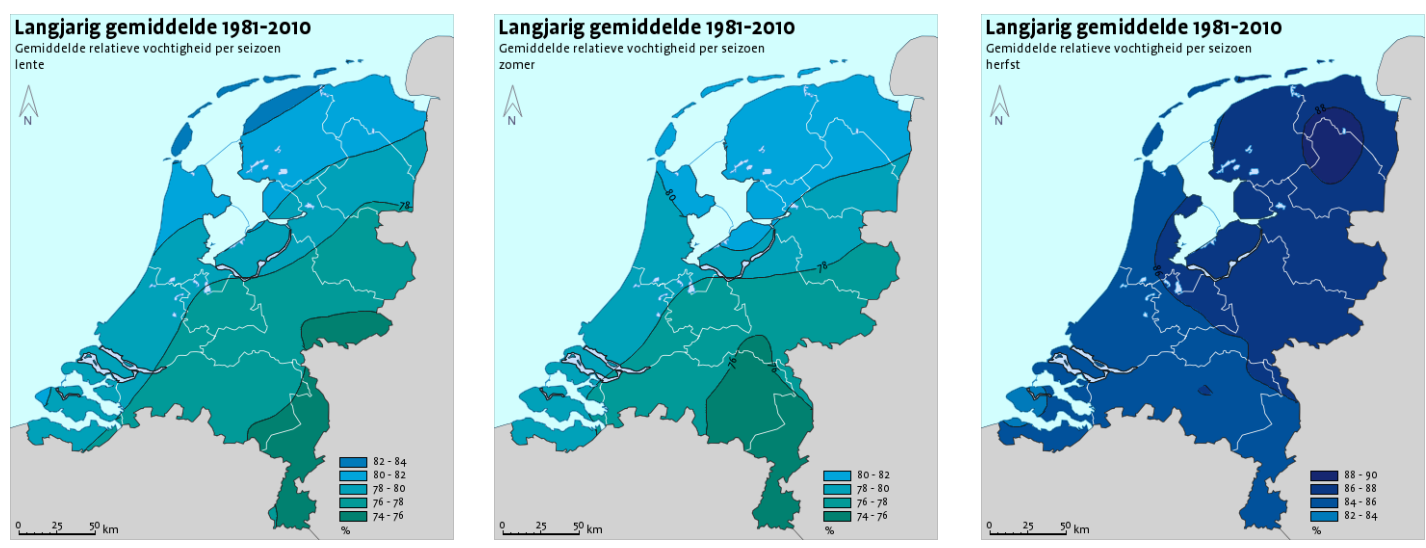

Figuur 8 Langjarig gemiddelde relatieve luchtvochtigheid in de lente, zomer en herfst in Nederland (KNMI, 2018).
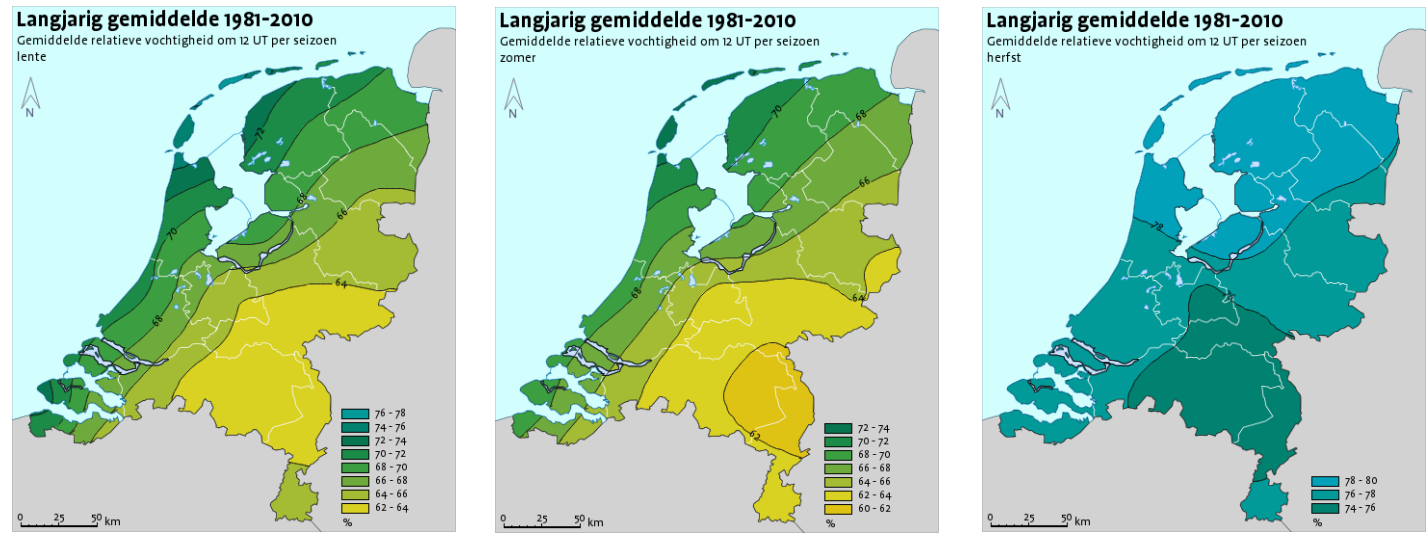

Figuur 9 Langjarig gemiddelde relatieve luchtvochtigheid om 12:00 in de lente, zomer en herfst in Nederland (KNMI, 2018).

De relatieve luchtvochtigheid liggen het hoogst in de kustregio's en nemen landinwaarts af. De relatieve luchtvochtigheid is het laagst tijdens de zomermaanden. Om 12:00 uur liggen de relatieve luchtvochtigheden onder het daggemiddelde.

\subsection{Klimaatverandering in Nederland}

In de periode $1981-2010$ is de gemiddelde temperatuur in de zomer toegenomen van $16,1^{\circ} \mathrm{C}$ naar $17,0^{\circ} \mathrm{C}$ en is de temperatuur op de warmste zomerdag toegenomen van $23,2^{\circ} \mathrm{C}$ naar $24,7^{\circ} \mathrm{C}$ ten opzichte van de periode 1951-1980. Verder is het aantal zomerse dagen (max temp. $\geq 25^{\circ} \mathrm{C}$ ) toegenomen van 13 naar 21 dagen, is zonnestraling toegenomen van 149 naar $153 \mathrm{~kJ} / \mathrm{cm}^{2}$ en is der relatieve luchtvochtigheid gedaald van $78 \%$ naar 77\% (KNMI, 2015).

Modelberekeningen voor 2030 laten in de zomer een gemiddelde temperatuurstijging zien van $0,9^{\circ} \mathrm{C}$ naar $17,9^{\circ} \mathrm{C}$ en een $1,9 \%$ toename in zonnestraling ten opzichte van de referentieperiode $1981-2010$ (KNMI, 2015).

Op basis van modelberekeningen in verschillende klimaatscenario's zijn de verwachtingen in veranderingen van het klimaat rond 2050 t.o.v. de referentieperiode 1981-2010 (KNMI, 2015):

- De temperatuur blijft stijgen $\left(1,0\right.$ tot $\left.2,3^{\circ} \mathrm{C}\right)$.

- Toename in het aantal zomerse dagen met een maximumtemperatuur van $25^{\circ} \mathrm{C}$ en hoger ( +22 tot $+70 \%)$

- Toename in tropische nachten met een minimumtemperatuur van minimaal $20^{\circ} \mathrm{C}(+0,5$ tot $+2,2 \%)$

- De verwachte opwarming in Nederland vertoont regionale verschillen. Op de warmste zomerdagen kan de temperatuur in het zuidoosten van Nederland ongeveer $1^{\circ} \mathrm{C}$ meer toenemen dan in het 
noordwesten. Regionale temperatuurverschillen tussen de kustregio en landinwaarts zullen toenemen.

- De veranderingen in windsnelheid zijn klein $(-2,5$ tot $0,9 \%)$.

- De hoeveelheid zonnestraling neemt licht toe (+1,0 tot 6,5\%).

- De veranderingen in relatieve luchtvochtigheid zijn klein $(-2,5$ tot $+0,1 \%)$. 


\section{Economische gevolgen van hittestress bij melkvee}

De economische gevolgen van hittestress bij melkkoeien bestaat enerzijds uit verminderde opbrengsten zoals een daling in melkproductie en anderzijds uit toename van kosten zoals een toename in inseminatiekosten als gevolg van slechter drachtig worden van het melkvee. De economische schade is sterk bedrijfsgebonden vanwege o.a. verschillen in klimaat (bijv. aantal zomerse dagen) als gevolg van de locatie van het bedrijf, afkalfpatroon (bijv. voorjaars- versus najaarsafkalvend) en de hoogte van de dagproductie van de melkkoeien. De in dit hoofdstuk berekende economische schade moet daarom slechts gezien worden als een indicatie van de schade die op kan treden als gevolg van hittestress. Hiernaast zijn ook de eventuele langere termijneffecten van hittestress in gematigde streken niet meegenomen zoals verminderde melkproductie in de volgende lactatie van droge koeien en effecten op het prestaties van het (ongeboren) kalf, omdat hierover geen informatie over deze langetermijneffecten in gematigde klimaatstreken beschikbaar was.

\subsection{Schatting van de economische effecten}

Op basis van het uitgevoerde literatuuronderzoek is een inschatting gemaakt van de economische effecten die worden veroorzaakt door hittestress. In tabel 1 staan de geschatte economische effecten op de melkopbrengst als gevolg van het optreden van hittestress bij melkkoeien.

Tabel 1 Geschatte economische effecten op melkopbrengsten door hittestress tijdens warme, zomerse en tropische dagen.

\begin{tabular}{lccc} 
Parameter & Warme dagen & Zomerse dagen & Tropische dagen \\
Daling in melkproductie per koe & $2,0 \%$ & $4,0 \%$ & $8,0 \%$ \\
\hline Daling in vetgehalte & $3,0 \%$ & $6,0 \%$ & $9,0 \%$ \\
\hline Daling in eiwitgehalte & $2,0 \%$ & $4,0 \%$ & $6,0 \%$ \\
\hline Celgetal & geen korting & geen korting & geen korting \\
\hline
\end{tabular}

Het gemiddelde celgetal van de geleverde melk in 2017 was 178.000 cellen per ml melk (Qlip, 2018). De kortingsgrens voor celgetal bedraagt 400.000 cellen per ml melk (Remmelink et al., 2017). De gerapporteerde toename in celgetal tijdens een periode van hittestress bedroeg maximaal $28 \%$ waarmee het gemiddelde celgetal naar 228.000 cellen per $\mathrm{ml}$ melk zou stijgen en waarmee het celgetal ruim onder de kortingsgrens blijft van 400.000 cellen per ml melk. Een korting op het melkgeld als gevolg van een te hoog celgetal wordt daarom over het algemeen niet verwacht.

Uit de onderzoekresultaten wordt het niet duidelijk in hoeverre hittestress leidt tot meer gevallen van klinische mastitis. Het celgetal is tijdens warme perioden weliswaar verhoogd en tijdens de zomer is het melktankcelgetal ook het hoogst, maar daarentegen blijkt de incidentie van klinische mastitis het hoogst te zijn in de winter. Om de kosten van een eventueel effect in beeld te krijgen is een inschatting gemaakt o.b.v. het voorkomen van extra mastitis bij melkkoeien. De incidentie van mastitis bedraagt gemiddeld 33\% (Hogenkamp, 2015). De gemiddelde bedrijfseconomische schade van een nieuw geval van klinische mastitis bedraagt $€ 301$ per koe (van Soest et al., 2016). Voor de inschatting is verondersteld dat de incidentie van mastitis op warme dagen met 2,5\%, op zomerse dagen met 5,0\% en op tropische dagen met $10,0 \%$ toeneemt.

De tussenkalftijd neemt toe doordat tochtige koeien slechter drachtig worden tijdens een periode van hittestress. Er is aangenomen dat de tussenkalftijd alleen toeneemt van de koeien die tijdens een periode van hittestress tochtig zijn waarbij tevens is aangenomen dat de koeien gespreid over het jaar afkalven. De toename in tussenkalftijd kan enerzijds veroorzaakt worden doordat de koeien tochtigheid slechter laten zien tijdens perioden van hittestress waardoor deze niet altijd wordt gesignaleerd door de veehouders en anderzijds doordat ze niet drachtig zijn geworden van een 
inseminatie. $\mathrm{Er}$ is ingeschat dat op warme dagen melkkoeien $25 \%$, op zomerse dagen $50 \%$ en op tropische dagen $75 \%$ slechter drachtig worden, waardoor de tussenkalftijd toeneemt. De kosten van een toename in tussenkalftijd verschillen tussen bedrijven. Cools et al. (2008) berekende een gemiddeld verlies van €2,08 per dag per koe. Hogeveen (2015) berekende de kosten van een verlengde tussenkalftijd voor een bedrijf met 100 koeien met een productie van 10.000 liter per koe op gemiddeld $€ 1,50$ per dag per koe. Voor de schatting van de economische effecten van een verlengde tussenkalftijd is uitgegaan van $€ 1,75$ per dag per koe.

$\mathrm{Er}$ is in gematigde streken geen onderzoek gedaan naar de effecten van hittestress op de klauwgezondheid. Aangezien in de praktijk geconstateerd wordt dat de klauwgezondheid afneemt na een periode van hittestress is getracht een grove inschatting te maken van de kosten die kunnen optreden als de klauwgezondheid afneemt. Er is een inschatting gemaakt o.b.v. het voorkomen van extra kreupelheid bij melkkoeien. Bierma et al. (2006) hebben de incidentie en kosten van klauwaandoeningen in beeld gebracht. De incidentie van kreupelheid in Nederland bedroeg gemiddeld $26 \%$ en de bedrijfseconomische schade bedroeg $€ 104$ per kreupele koe. Voor de inschatting is verondersteld dat de incidentie van kreupelheid op warme dagen met 2,5\%, op zomerse dagen met $5,0 \%$ en op tropische dagen met $10,0 \%$ toeneemt.

De volgende economische effecten zijn niet meegenomen omdat onduidelijk is of er effecten zijn onder gematigde klimaatomstandigheden en wat de eventuele grootte daarvan zou zijn:

- Opfokresultaten van jongvee

- Melkproductie in de volgende lactatie van droge koeien die last hadden van hittestress

- Melkproductie van nakomelingen van koeien die last hadden van hittestress

- Verminderde weerstand en toename in ziekten

- Levensduur

\subsection{Bedrijfsscenario's}

Voor de berekening van de totale bedrijfseconomische gevolgen van hittestress is uitgegaan van een ficitief melkveebedrijf met de volgende kenmerken:

- Aantal melkkoeien 100

- Melkproductie per jaar

$8.500 \mathrm{~kg} / \mathrm{koe}$

- Vetgehalte

$4,26 \%$

- Eiwitgehalte

$3,48 \%$

- Meetmelkproductie per jaar

$8.840 \mathrm{~kg} / \mathrm{koe}$

- Melkprijs in juni t/m september

$€ 34,50$ per liter

- Vetprijs in juni $\mathrm{t} / \mathrm{m}$ september

$€ 2,07$ per $\mathrm{kg}$

- Eiwitprijs in juni $\mathrm{t} / \mathrm{m}$ september

$€ 4,13$ per $\mathrm{kg}$

- Tussenkalftijd

- Non-return percentage 56 dagen

407 dagen

$65 \%$

De verandering in technische resultaten voor dit bedrijf op warme, zomerse en tropische dagen zijn berekend aan de hand van de inschattingen uit paragraaf 4.1. In tabel 2 zijn de technische resultaten van dit bedrijf op normale dagen $\left(T<20^{\circ} \mathrm{C}\right)$, warme dagen $\left(T>20^{\circ} \mathrm{C}\right)$, zomerse $\left(T>25^{\circ} \mathrm{C}\right)$ en tropische dagen $\left(T>30^{\circ} \mathrm{C}\right)$ weergegeven.

Tabel 2 Technische resultaten van het fictieve bedrijf tijdens normale dagen $\left(T<20^{\circ} \mathrm{C}\right)$, warme dagen $\left(T>20^{\circ} \mathrm{C}\right)$, zomerse $\left(T>25^{\circ} \mathrm{C}\right)$ en tropische dagen $\left(T>30^{\circ} \mathrm{C}\right)$.

\begin{tabular}{|c|c|c|c|c|}
\hline Scenario & Normaal & Warme dagen & Zomerse dagen & Tropische dagen \\
\hline Melkproductie (kg melk/koe/dag) & 27,9 & 27,3 & 26,8 & 25,6 \\
\hline Vetgehalte & $4,26 \%$ & $4,13 \%$ & $4,00 \%$ & $3,88 \%$ \\
\hline Non-return percentage 56 dagen & $65 \%$ & $49 \%$ & $33 \%$ & $16 \%$ \\
\hline Incidentie kreupelheid & $26,0 \%$ & $28,5 \%$ & $31,0 \%$ & $36,0 \%$ \\
\hline Incidentie mastitis & $33,0 \%$ & $35,5 \%$ & $38,0 \%$ & $43,0 \%$ \\
\hline
\end{tabular}


Er zijn drie hittestress scenario's doorgerekend voor dit fictieve melkveebedrijf:

1. Weinig hittestress dagen: 46 warme dagen, 12 zomerse dagen en 2 tropische dagen

2. Gemiddeld hittestress dagen: 56 warme dagen, 20 zomerse dagen en 4 tropische dagen

3. Veel hittestress dagen: 66 warme dagen, 28 zomerse dagen en 6 tropische dagen

In tabel 3 staan per hittestress scenario de effecten weergegeven op de hoeveelheid geleverde melk, vet en eiwit en het effect op de tussenkalftijd van het fictieve melkveebedrijf.

Tabel 3 De berekende effecten op jaarbasis voor het fictieve melkveebedrijf met 100 melkkoeien op de hoeveelheid geleverde melk, vet, eiwit en tussenkalftijd bij geen, weinig, gemiddeld en veel hittestress dagen.

\begin{tabular}{lcccc} 
Scenario & Geen & Weinig & Gemiddeld & Veel \\
Melkproductie (kg/jaar) & 850.000 & 845.652 & 843.757 & 341.862 \\
\hline Vet (kg/jaar) & 36.210 & 35.939 & 35.825 & 35.711 \\
\hline Eiwit (kg/jaar) & 29.580 & 29.433 & 29.371 & 29.308 \\
\hline Tussenkalftijd (dagen) & 407,0 & 407,7 & 408,0 & 408,3 \\
\hline
\end{tabular}

In tabel 4 staan per hittestress scenario de berekende verminderde melkgeldopbrengsten en toename in kosten op jaarbasis bij weinig, gemiddeld en veel hittestress dagen op het fictieve melkveebedrijf weergegeven.

Tabel 4 De berekende verminderde melkopbrengsten en toename in kosten op jaarbasis bij weinig, gemiddeld en veel hittestress dagen op het fictieve melkveebedrijf van 100 melkkoeien.

\begin{tabular}{lccc} 
Scenario & Weinig & Gemiddeld & Veel \\
Verminderde geleverde kg melk & $€ 1.500$ & $€ 2.154$ & $€ 2.808$ \\
\hline Verminderde geleverde kg vet & $€ 559$ & $€ 794$ & $€ 1.030$ \\
\hline Verminderde geleverde kg eiwit & $€ 609$ & $€ 866$ & $€ 1.122$ \\
\hline Toename in tussenkalftijd & $€ 124$ & $€ 177$ & $€ 229$ \\
\hline Verslechtering in klauwgezondheid & $€ 56$ & $€ 80$ & $€ 104$ \\
\hline Verslechtering in uiergezondheid & $€ 161$ & $€ 231$ & $€ 301$ \\
\hline Totaal kosten per jaar & $\mathbf{6 3 . 0 0 8}$ & $\mathbf{6 4 . 3 0 1}$ & $\mathbf{C 5 . 5 9 3}$ \\
\hline
\end{tabular}

Het grootste bedrijfseconomische effect wordt veroorzaakt door de daling in melkproductie gevolgd door een afname in de geleverde hoeveelheid vet en eiwit. De economische effecten van tussenkalftijd, klauwgezondheid en uiergezondheid bedragen circa $10 \%$ van de totale kosten. 


\section{$5 \quad$ Verkenning van opties om hittestress bij weidegang te reduceren}

In een workshop met personen met verschillende achtergronden (melkveehouders, (voer)adviseurs, veeartsen en onderzoekers) is verkend welke ideeën er leven om hittestress bij weidegang te kunnen verminderen. Deze ideeën staan hieronder weergegeven en zijn aangevuld met informatie uit andere bronnen. Het betrof een verkenning van ideeën om zo een overzichtsbeeld te vormen waar de (perspectiefvolle) oplossingsrichtingen gezocht dienen te worden, en niet om volledig uitgewerkte oplossingen aan te kunnen bieden. Daarbij komt dat een bepaalde oplossingsrichting in de ene situatie wel zal werken en in een andere situatie juist niet.

\subsection{Weide- en veemanagement}

Aanpassen van het weidemanagement

Het aanpassen van het weidemanagement om de gevolgen van hittestress tegen te gaan is een maatregel die men direct kan toepassen. Hierbij zijn weinig tot geen investeringen nodig maar soms wel een (drastische) verandering van de bedrijfsvoering. Het variëren van het moment van de dag dat de koeien geweid worden, zodat de zonnebelasting op de koeien wordt verminderd, kan op verschillende manieren worden ingevuld:

- 's avonds en 's nachts weiden.

- Direct na het melken 's ochtends en 's avonds de koeien weiden (bijv. van 7:00-10:00 uur en van 19:00-22:00), zodat de koeien tijdens de heetste periode van de dag met de meeste zonneinstraling op stal zijn.

- De koeien overdag weiden in percelen waar ze schaduw tot hun beschikking hebben en 's nachts in percelen zonder schaduwmogelijkheden.

- Eerder in het jaar gaan weiden en/of langer in het seizoen doorweiden om ruimte te winnen voor het kunnen opstallen van de koeien tijdens zomerse en tropische dagen midden in de zomer. Op deze manier kan met behoud van weidepremie, waarvoor een minimaal aantal weidedagen per jaar vereist is, rekening worden gehouden met hittestress.

- Vormen van beweidings- en stalsystemen waarbij koeien de keuzevrijheid hebben in toegang tot weide, schaduw, verkoeling en/of stal.

- Sneller rouleren, roteren of stripgrazen van de koppel koeien kan tijdens warmere perioden helpen om te zorgen voor gras met voldoende smakelijkheid en voederwaarde, waarbij men in de gaten dient te houden dat er op langere termijn voldoende grasaanbod overblijft.

Bij beweiden geldt jong geleerd, oud gedaan. Jongvee wat heeft geleerd om te weiden onder variabele omstandigheden zal als koe beter in staat zijn om te gaan met (noodzakelijke) wisselingen in het weidemanagement.

Voordelen:

- Geen (of weinig) investeringen nodig

- Flexibel in te zetten

Nadelen:

- Aanpassen van weidemanagement betekent veranderingen voor de koeien, terwijl je juist veranderingen zo geleidelijk mogelijk wilt doorvoeren voor optimaal comfort van de koeien.

- Het is bedrijfsafhankelijk in hoeverre men het weidemanagement kan aanpassen. Het ene bedrijf (of ondernemer) kan makkelijker het weidemanagement binnen zijn bedrijf aanpassen dan het andere bedrijf.

- Bij het geven van keuzevrijheid aan de koeien waarbij ze zelf bepalen of ze in de stal of wei zijn, kan het zijn dat deze dagen niet zullen voldoen de definitie weidedag om in aanmerking te komen voor de weidepremie. Maar als door stijgende temperaturen en zonne-instraling hittestress vaker gaat voorkomen, dan zou de definitie ook herzien kunnen worden door de stichting Weidegang om flexibeler te kunnen inspelen op veranderde weersomstandigheden. 
Benutting van de aanwezige variatie in de koppel koeien

Een andere optie om de effecten van hittestress te verminderen is door het benutten van de aanwezige variatie in de koppel koeien. Koeien reageren verschillend op hittestress en deze variatie is te benutten.

Mogelijke opties voor het benutten van de variatie zijn:

- Het effect op hoogproductieve koeien is groter dan op laagproductieve koeien. Gekozen kan worden om tijdens zomerse en tropische dagen alleen de laagproductieve te weiden.

- Door na te gaan welke koeien wel of niet goed tegen zon en warmte kunnen kan je middels een selectiepoort alleen de koeien laten weiden die het best met warme, zomerse condities om kunnen gaan.

- Om de effecten van verminderde drachtigheid te verminderen en mogelijke negatieve effecten op de langere termijn te beperken kan men ervoor kiezen om de droge koeien en de koeien die binnenkort geïnsemineerd moeten worden binnen te houden.

- Het koppel opsplitsen in een groep weiders en niet weiders om zo het beschikbare weidegras in te zetten bij de groep waarbij dit het beste past. Hoogproductieve koeien zouden in het voorjaar kunnen weiden bij hoge graskwaliteit, en laagproductieve dieren in de zomer bij lagere graskwaliteit.

Voordelen:

- Door 'risico'-dieren apart te behandelen kunnen de grootste negatieve effecten van hittestress verminderd worden.

- De aandacht van de veehouder kan meer gericht worden op de 'risico'-dieren.

- Koeien blijven zichtbaar in de wei voor de burger.

Nadelen:

- Opsplitsing van het koppel in meerdere groepen vergt mogelijk aanpassingen in de bedrijfsvoering die extra kosten en/of arbeid met zich mee kunnen brengen.

- De aandacht van de melkveehouder moet worden verdeeld over meerdere koppels en individuele koeien.

- Voor de koeien op de stal zullen aanpassingen in het voerrantsoen moeten worden gemaakt, eventueel met het op stal voeren van verse gras.

- Bij al deze vormen zal gelden dat ze alleen als weidedag voor de weidepremie meegeteld kunnen worden als ze binnen de definitie van weidegang vallen zoals die door de Stichting Weidegang is gesteld. Maar als door stijgende temperaturen en zonne-instraling hittestress vaker gaat voorkomen, dan zou de definitie ook herzien kunnen worden door de stichting Weidegang om flexibeler te kunnen inspelen op veranderde weersomstandigheden.

Vermijden van stress tijdens perioden van hittestress

Het verminderen van het aantal stressmomenten (opjagen, wisselen rantsoen, zo min mogelijk verandering) kan mogelijk bijdragen om de negatieve gevolgen van hittestress te beperken. Stress verminderen kan door te zorgen voor een vaste regelmaat bij het verstrekken van voer, melken en het weiden en wijzigingen in de samenstelling van het rantsoen beperkt te houden. Vaste ritmes en zo weinig mogelijke veranderingen zijn belangrijk om stress te vermijden. Verder kan men ervoor kiezen om veebehandelingen en het verplaatsen van dieren op koelere momenten van de dag uit te voeren.

Voordelen:

- Een vast ritme zorgt voor structuur voor zowel de koeien als de veehouder.

Nadelen:

- Zo min mogelijk verandering kan strijdig zijn met andere maatregelen tijdens perioden van langere hittestress.

Inzetten van monitoringstools

Met behulp van monitoringstools kan een 'early-warning' systeem worden gemaakt om de veehouder tijdig te kunnen waarschuwen voor het gaan optreden van hittestress zodat tijdig en adequaat 
maatregelen genomen kunnen worden om de gevolgen van hittestress te vermijden. Bestaande sensoren en dataverzameling op een melkveebedrijf kunnen hiervoor gebruikt worden.

- Onderzoek van Abeni en Galli (2017) laat zien dat er relaties bestaan tussen een toenemende THI en toename in koe-activiteit en afname in herkauwtijd. Aanvullende waarnemingen zijn nodig onder verschillende omstandigheden (verschillen in koerassen en management) om drempelwaarden te kunnen vaststellen voor het geven van waarschuwingen aan de veehouder.

- Via tijdserie analyses van de dagelijkse melkproductie i.c.m. de dagelijkse buitentemperatuur van het dichtstbijzijnde weerstation blijkt het mogelijk te zijn om per koe de effecten van hittestress te bepalen. Deze informatie kan dienen om te bepalen wanneer hittestress optreedt (André et al., 2011).

De tool dient wel tijdig (minimaal 1 à 2 dagen van tevoren) een signaal door te geven dat hittestress er zit aan te komen. Koppeling van met lokale weersdata en weersvoorspelling ligt dan ook voor de hand.

Voordelen:

- Bestaande data kunnen gebruikt worden om monitoringstools te maken.

- Informatie is bedrijfs- en koespecifiek.

Nadelen:

- Er is aanvullend onderzoek en ontwikkeling nodig om de monitoringtools praktijkrijp te maken.

- De veehouder dient te leren werken met dergelijke monitoringtools en deze in te passen in het management.

\subsection{Voeding en water}

Aanpassen voeding en zorgen voor goede drinkwatervoorzieningen $\mathrm{Bij}$ toenemende temperatuur neemt de behoefte aan drinkwater bij koeien toe. Het is derhalve essentieel om te zorgen voor voldoende goede kwaliteit drinkwater in de wei. Het aanvoerdebiet (liters water per minuut) van de drinkwatervoorzieningen dient hoog genoeg te zijn om de gehele koppel voldoende drinkwater te kunnen geven. Sneller rouleren, roteren of stripgrazen van de koppel koeien kan tijdens warmere perioden helpen om te zorgen voor gras met voldoende smakelijkheid en voederwaarde, waarbij men wel in de gaten dient te houden dat de koeien op de langere termijn ook voldoende grasaanbod blijven houden. Daarnaast kan men zorgen voor een lagere productie van lichaamswarmte door beter verteerbaar ruwvoer te voeren en een energierijker rantsoen te voeren, waarbij wel onderscheid dient te worden gemaakt tussen zetmeel en vet vanwege het verschil in fysiologische reactie. Om energierijker te kunnen voeren moet er wel ruimte zijn om het energieniveau in het rantsoen te kunnen verhogen. Als men al op een maximaal energieniveau zit, dan zal er vanwege darmgezondheid geen ruimte meer zijn om dit niveau nog verder te verhogen. Rantsoenaanpassingen vergen maatwerk en kunnen in overleg met de voeradviseur en dierenarts worden gedaan. Verder kan men overwegen om vaker kleinere porties voer te verstrekken en om op koelere momenten van de dag vers voer te verstrekken. Tijdens warme zomerse perioden vergt het voorkomen van broei in de kuilen extra aandacht om de versheid en smakelijkheid van het voer te kunnen waarborgen. Ook de mineralenvoorziening vergt extra aandacht voor zowel melkvee als jongvee.

Voordelen:

- Goede drinkwatervoorzieningen zorgen voor een optimale vochtvoorziening van de koeien.

- Aanpassingen in het rantsoen zijn relatief makkelijk door te voeren.

Nadelen:

- Afhankelijk van de aanpassingen kan een energierijker rantsoen ervoor zorgen dat het eigen ruwvoer minder goed benut wordt en dat meer krachtvoer moet worden gevoerd, wat zorgt voor extra aanvoer van stikstof $(N)$ en fosfor $(P)$.

- De daling in melkproductie tijdens hittestress lijkt maar deels (35-50\%) te worden veroorzaakt door de lagere droge stof opname (Rhoads et al., 2009; Wheelock et al., 2010). Het effect van rantsoenaanpassingen op de melkproductie lijkt dan ook niet al te groot te zijn. 


\subsection{Fokkerij}

\section{Aanpassen inseminatiestrategie}

Het aanpassen van de inseminatie tijdens een warme periode kan leiden tot een beter drachtigheidspercentage. Dit blijkt uit een Duits onderzoek (Schüller et al., 2015), waarbij betere drachtigheidspercentages werden bereikt door:

- Tijdens warme zomerse condities geen vers sperma maar bevroren sperma te gebruiken,

- Tijdens warme zomerse condities natuurlijke dekking toe te passen i.p.v. KI.

Men zou ook het afkalfpatroon kunnen aanpassen waardoor minder koeien tijdens warme, zomerse perioden tochtig zijn. Men kan ook langere tussenkalftijden accepteren en tijdens warme periodes de koeien niet insemineren zodat geen kosten worden gemaakt.

Voordelen:

- Voor bedrijven die vers sperma gebruiken zal het overschakelen naar bevroren sperma makkelijk te doen zijn.

- Het gebruik maken van een stier voor natuurlijke dekking in de zomermaanden kan voor bepaalde bedrijven een relatief eenvoudige oplossing zijn om betere drachtigheidspercentages te halen tijdens warme condities in de zomer.

Nadelen:

- Natuurlijke dekking met een stier is niet voor ieder bedrijf praktisch toepasbaar en kan ook gevaarlijke situaties voor de veehouder opleveren.

\section{Aanpassen fokdoel}

Er blijkt een genetische invloed te zijn op hittestress bij Holstein koeien zo bleek uit Italiaans onderzoek (Bernabucci et al., 2014):

- Stieren met dezelfde genetische waarde voor melkproductie reageren verschillend op toenemende THI. Het meenemen van het effect van THI in de fokwaarden berekening verandert de ranking van de stieren, waardoor het voor veehouders mogelijk wordt om koeien te fokken die beter bestand zijn tegen hittestress. Op dit moment wordt echter nog geen rekening gehouden bij ranking met de THI.

- Inzet van andere rassen kan mogelijk de gevolgen van hittestress verminderen. Bij een NieuwZeelands onderzoek (Bryant et al., 2007) waren de effecten bij Jerseys kleiner dan bij HolsteinFriesian (HF). Echter de melkproductie van Jerseys was ook lager dan van de HF's waardoor het de vraag is of het een effect is van alleen ras of dat de hoogte van de melkproductie ook een rol speelde. Mogelijk dat de grootte van de koeien hierin ook een rol speelt, aangezien Jerseys kleiner zijn dan HF's. Niet uitgesloten is ook dat haarkleur (incl. aandeel wit-zwart) ook een rol speelt, immers zwart absorbeert meer licht en energie dan wit. Zo bleek bij vleesveekalveren haarkleur een significant effect te hebben op de vaginale temperatuur als gevolg van de zonne-instraling, waarbij Black Angus kalveren een 0,1 tot $0,2^{\circ} \mathrm{C}$ hogere vaginale temperatuur hadden dan witte Charolais kalveren (Gebremedhin et al., 2011), maar huidskleur heeft hier een verstrengelend effect met ras. Onderzoek binnen een ras is nodig om invloed van huidskleur te kunnen bepalen.

Voordelen:

- Het aanpassen van het fokdoel, mits weloverwogen, kan op relatief eenvoudige manier worden geïmplementeerd.

Nadelen:

- Aanpassen van het fokdoel geeft pas op lange termijn resultaat.

- Nader onderzoek naar de relatie tussen weerdata en vruchtbaarheid zal nodig zijn om effecten van hittestress op de stierprestaties onder Nederlandse omstandigheden te kunnen identificeren. 


\subsection{Kunstmatige schaduw en koeling in de wei}

\section{Plaatsen van schaduwdoeken}

Het kunstmatig realiseren van schaduw, in de vorm van schaduwdoeken, is een relatief snelle en eenvoudige manier om schaduw te verstrekken aan koeien. Dit kan op verschillende manieren worden ingevuld:

- Ophangen van semipermanente schaduwdoeken in het weiland die men bij aanvang van de eerste warmteperiode ophangt en na de laatste warmteperiode weer weghaalt.

- Ophangen van harmonica schaduwdoeken die men bij een warme periode eenvoudig kan uitschuiven en na afloop van de warme periode weer in kan schuiven zodat zonlicht en regen ook onder het schaduwdoek terecht kan komen.

- Ophangen van schaduwdoeken op verschillende plekken boven het kavelpad. Uit Australisch onderzoek bij een AMS bleek dat bij deze aanpak de koeien met schaduwplekken (elke $150 \mathrm{~m}$ ) op het kavelpad (930 m lang) aanzienlijk meer geneigd waren om grotere afstanden af te leggen, en tevens een lagere lichaamstemperatuur en hartslag hadden dan de koeien zonder schaduwplekken boven het kavelpad (Wildridge et al., 2016).

Voordelen:

- Kunstmatige schaduwplekken kunnen snel gerealiseerd worden.

Nadelen:

- Vaste kunstmatige plekken in het weiland kunnen leiden tot een slechtere grasmat (vertrapping), overbemesting en lagere grasproductie onder het schaduwdoek.

- Vaste schaduwplekken in het land vormen een obstakel bij het bemesten en grasmaaien, schudden, harken en oogsten.

- Schaduwplekken boven het kavelpad kunnen een obstakel vormen voor trekkerverkeer. En als deze hoog worden geplaatst, om geen overlast te veroorzaken voor trekkerverkeer, kan op bepaalde tijden van de dag door de hoogte van het systeem de schaduw buiten het kavelpad vallen.

Gebruik van verplaatsbare schaduwdoeken

Een mobiel verplaatsbaar schaduwscherm biedt de mogelijkheid om schaduw te verstrekken en tevens te sturen op het graas- en mestgedrag van de koeien zodat vertrapping en overbemesting van bepaalde plekken in het land wordt vermeden. Verplaatsbare schaduwschermen zijn zelf te maken of te koop. De Universiteit van Missouri heeft een zelfbouw plan geschreven voor een verplaatsbaar schaduwscherm, dat te downloaden is via Internet (Zulovich, 1998). Op Internet zijn meer voorbeelden te zien van verplaatsbare constructies met schaduwdoeken die een handige veehouder zelf zou kunnen maken. Bedrijven die verplaatsbare schaduwschermen verkopen zijn o.a. de Amerikaanse firma's Shade Haven en Rush-Co. Shade Haven verkoopt een verplaatsbaar schaduwdoek wat een waaier op een onderstel is die opengeklapt wordt door de veehouder zodra het schaduwdoek op zijn gewenste plaats staat. De grootste versie heeft een oppervlak van $111 \mathrm{~m}^{2}$ waar volgens de firma 50 à 60 koeien onder staan, maar geeft volgens de firma een effectieve schaduwverstrekking aan een koppel van 75 koeien aangezien niet alle koeien tegelijk onder het schaduwdoek zullen staan. Naast het verminderen van de zonne-instraling zorgt het schaduwdoek ook voor een natuurlijke (verkoelende) trek onder het doek. Rush-Co verkoopt een verplaatsbaar schaduwscherm dat opgetild kan worden met pallet-lepels en zo verplaatst kan worden. De grootste versie heeft een oppervlak van $156 \mathrm{~m}^{2}$ en kan volgens de firma schaduw bieden aan ongeveer 100 koeien.

Voordelen:

- Een mobiel schaduwscherm kan met de koeien mee omweiden naar een ander perceel.

- Het graas- en mestgedrag is te sturen waardoor vertrapping en overbemesting van bepaalde plekken in het land wordt voorkomen.

Nadelen:

- Investeringskosten voor het maken of kopen van een schaduwscherm.

- Extra arbeid voor het verplaatsen van het schaduwscherm. 


\section{Pleksgewijs zonnepanelen in de wei plaatsen}

Naast het plaatsen van zonnepanelen op daken kan men ook zonnepanelen plaatsen in de zogenoemde zonneweides, weides die vol zijn gelegd met zonnepanelen. Het nadeel van zonneweides is dat ze vruchtbare land onttrekken aan de productie van voedsel voor humane consumptie en voer voor dieren. Dit nadeel van zonneweides kan worden voorkomen door pleksgewijs zonnepanelen op hoogte te plaatsen, zodat koeien en trekkers er makkelijk onderdoor kunnen gaan. Verschillende configuraties van zonnepanelen zijn mogelijk, bijvoorbeeld een groter aantal zonnepanelen in één vlak die met de zon meedraaien voor maximale zonneopbrengst of een aantal kleinere oppervlakten zonnepanelen om zo koeien op verschillende plekken in de wei schaduw te kunnen bieden. Misschien dat in de toekomst een rijdend zonnepanelenscherm ontwikkeld wordt dat met de koeien mee weidt en verwisselbare accu's oplaadt die op andere plekken en/of in voertuigen gebruikt kunnen worden.

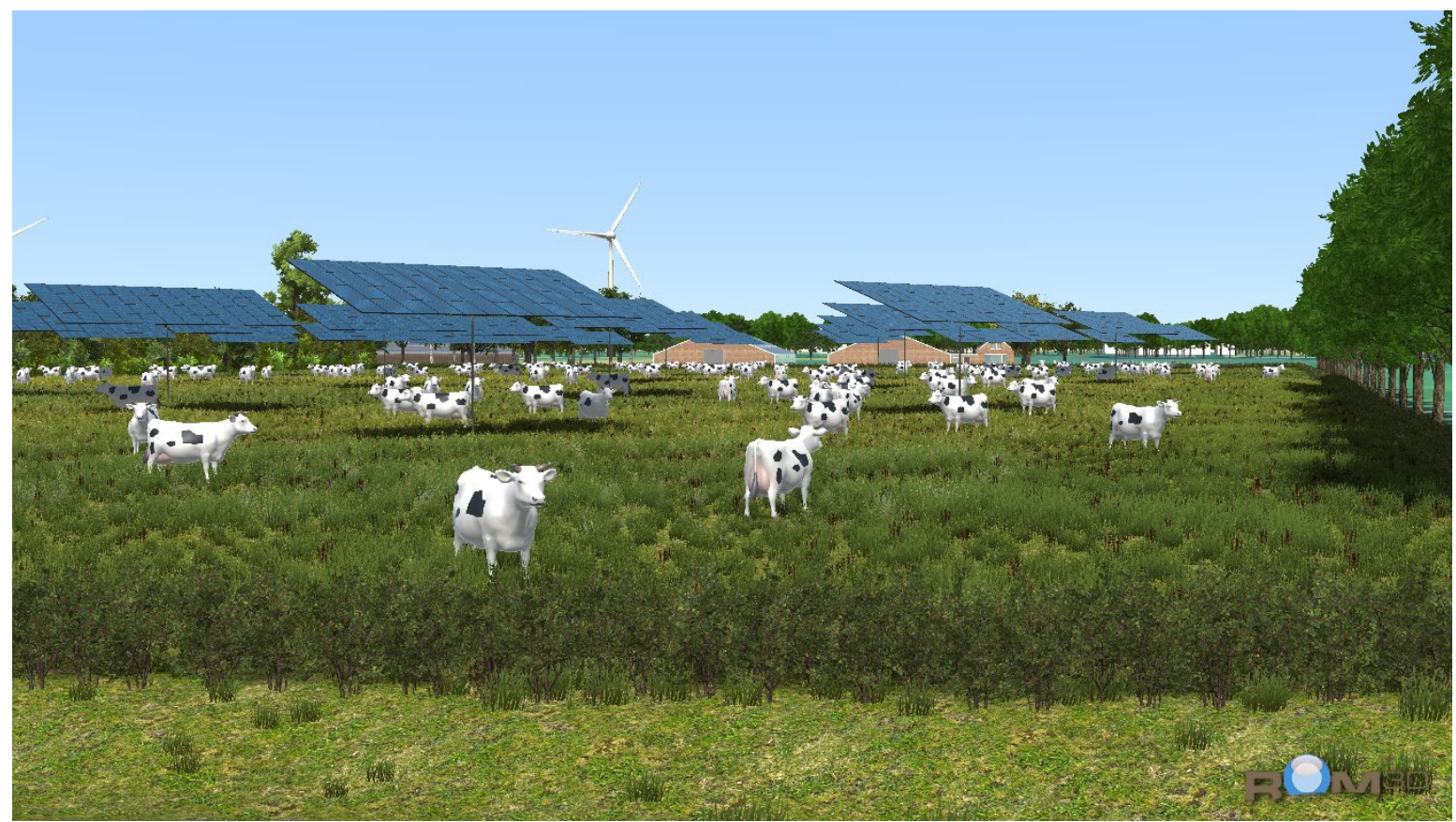

Figuur 10 Artist impression van plekgewijze plaatsing van zonnepanelen in de wei (Rienks, 2018).

Voordelen:

- Levert duurzame energieproductie en vermindert daarmee de $\mathrm{CO}_{2}$-footprint van de melkveehouderij.

Nadelen:

- Inpassingen van zonnepalen op vaste plekken in het weiland zal maatwerk vergen qua vergunningverlening. Niet alle gemeenten zijn in voor het pleksgewijs plaatsen van zonnepanelen.

- Zonnepanelen op voorgestelde hoogte vergt een hogere investering.

- Zonnepanelen op vaste plekken bemoeilijkt vruchtwisseling met andere gewassen.

- Zonnepanelen beïnvloeden of verstoren het landschap, wat niet altijd gewaardeerd (en gehonoreerd) wordt.

\section{Koelen van koeien}

De negatieve effecten van hittestress kunnen ook verminderd worden door koeien de mogelijkheid tot afkoeling te bieden. Dit kan op verschillende manieren in de weide gebeuren:

- Toegang geven tot een poel, beek of rivier waar koeien naar behoefte in kunnen gaan om zichzelf te koelen.

- Op het kavelpad of in de wei vernevelaars of sproeiers (douche/koelstraat) ophangen die koeien zelf kunnen aanzetten zoals een koe ook gebruik maakt van een koeborstel in de stal.

- In plaats van water vernevelen of sproeien zou ook gebruik gemaakt kunnen worden van blowers (evt. geregeld op windsnelheid) om luchtstroming op bepaalde plekken in de wei of het kavelpad die een verkoelend effect hebben op de koeien. 
- Vernevelaars, sproeiers of blowers kan men ook combineren op plekken waar schaduw wordt verstrekt bijvoorbeeld onder schaduwdoeken of zonnepanelen.

- Men kan ook beregenen combineren met weidegang, mits de apparatuur niet wordt beschadigd door de koeien.

- Als men de koeien overdag op stal houdt en 's avonds en 's nachts weidt kan men de stal van koeling/airco voorzien om de temperatuur in de stal te verlagen.

- Zonnepanelen geven tijdens zonnige perioden een hoge productie van elektra wat gebruikt kan worden voor energievoorziening van de koeling en/of airco op het bedrijf.

- Mogelijk dat scheren van koeien ook kan bijdragen aan verkoeling.

Voordelen:

- Koelen verbetert de melkproductie en verlaagt de rectale en lichaamstemperatuur (Kendall et al., 2007; Valtorta en Gallardo, 2004).

- Verstrekking van koeling op vrijwillige basis zorgt ervoor dat alleen de koeien die daar behoefte aan hebben er gebruik van zullen maken.

Nadelen:

- Inzet van vernevelaar, sproeiers of blowers vergt investeringskosten.

- Inzet van drinkwater voor verkoeling kost geld.

- Onduidelijk is wat effectieve vormen van koeling voor koeien zijn en waar men de koeien het beste kan koelen, zowel de plek in de wei/kavelpad als bij de koe zelf (uier, rug, kop, etc.).

\subsection{Biodiversiteit, beplanting en inrichting landschap}

Verstrekken van schaduw via landschapsbomen

Het verstrekken van schaduw via bomen en struiken is een voor de hand liggende optie. Van oudsher maakten bomen en struiken onderdeel uit van het landschap, ook op het boerenbedrijf. Versobering van landschap is een maatschappelijk issue geworden en de inpassing van nieuwe biodiversiteit staat ook in de melkveehouderijsector op de agenda. Echter, het inpassen van bomen en struiken in de bedrijfsvoering en het landschap is niet vanzelfsprekend en vergt maatwerk. Het is zoeken naar combinaties van bomen en struiken die goed ingepast kunnen worden in de bedrijfsvoering, een verrijking bieden voor (cultuur-historisch)landschap (dus ook inheemse soorten) waardoor een goede aanvulling ontstaat die zorgt voor meerwaarde op het bedrijf en voor de omgeving. Vragen die hierbij gesteld moeten worden zijn: welk soort (inheemse) bomen of heesters, hoeveelheid bomen om voldoende schaduw te kunnen creëren, de plantlocatie van de bomen en de vorm (alleenstaand, in houtwallen, heggen, etc.), wat levert het op (bijv. houtverkoop, energieproductie), en valt het onder de vergroeningsmaatregelen, en daarmee in de subsidiemogelijkheden, in het kader van het huidige of aanstaande GLB beleid van de EU.

Voordelen:

- Afhankelijk van het soort kunnen bomen een bijdrage leveren aan o.a. ontwatering van natte plekken, fungeren als waterpomp op droge gronden en het naar boven halen van mineralen uit diepere bodemlagen (van Eekeren et al., 2014).

- Bomen dragen bij aan een positieve uitstraling van het bedrijf.

- Kan mogelijkheden bieden voor extra inkomsten via agroforestry (informatie over agroforestry in Nederland, zie www.agro-forestry. $\mathrm{nl}$ ) of eventueel natuur-inclusieve landbouw. Een voorbeeld van agroforestry is een hoogstam fruitboomgaard waaronder jongvee wordt geweid en fruit van de bomen wordt verkocht.

Nadelen:

- Bomen vangen zonlicht weg van het gras wat in de schaduw van de bomen groeit, waardoor bij bomen een wat lagere grasopbrengst zal worden gerealiseerd.

- Plaatsing van bomen en planten midden in het perceel beperkt het gebruik van machines aanzienlijk.

- De groei van een boom vraagt vele jaren. 
- Bij vaste plekken heb je eerder kans op overbemesting en vertrapping. Dit nadeel kan ondervangen worden door te zorgen dat koeien kunnen rouleren over percelen waar ze schaduw via bomen tot hun beschikking hebben.

- Op veengrond is aanplant en groei van bomen lastig.

- Historische open landschappen combineren niet met de aanplant van bomen.

\section{Verstrekken van schaduw via voederbomen}

Met het aanplanten van voerderbomen kan een gevarieerder voeraanbod verstrekt worden aan koeien. De bladeren van deze bomen en struiken kunnen een aanvulling op het rantsoen van de koeien zijn, omdat ze een bron zijn van eiwitten, mineralen en sporenelementen. Daarnaast bevatten veel bomen secundaire plantenstoffen die een positief effect kunnen hebben op de vertering en de gezondheid van koeien. Door soortkeuze en beplantingsinrichting kan concurrentie voor licht beperkt worden. Het gebruik van bomen als voer reduceert door de oogst van blad ook de concurrentie voor licht voor het gras (van Eekeren et al., 2014). In een verkennende studie bleek dat niet alle koeien de bladeren van wilgen eten. Onduidelijk is waarom bepaalde koeien wel en bepaalde koeien de bladeren juist niet eten. Mogelijke oorzaken kunnen zijn dat het eten van bladeren een aangeleerd gedrag is of dat de bladeren alleen gegeten worden als individuele koeien daarmee een specifieke (mineralen) behoefte kunnen invullen (Roelen, 2017). Op de website www.voederbomen.nl/voederwaarden wordt een overzicht gegeven van de mineralengehalten van verschillende voederbomen (Luske et al., 2017). Meer informatie over het gebruik van voederwaarden en teelt van voederbomen is te vinden op www.voederbomen.nl en in de brochure 'Voederbomen in de landbouw' (van Eekeren et al., 2014).

\section{Voordelen:}

- Grotere variatie in het voeraanbod van koeien.

- Koeien kunnen zelf naar behoefte bladeren selecteren en eten.

- Voederbomen kunnen additionele positieve effecten hebben in de vorm van o.a. verbetering van lucht-, water- en bodemkwaliteit en $\mathrm{CO}_{2}$-vastlegging (van Eekeren et al., 2014).

Nadelen:

- Er is nog weinig bekend over de voederwaarde en opbrengst van voederbomen waardoor het nog lastig om dit goed in te rekenen in het rantsoen.

- Er dient een specifiek ontwerp en plan van aanpak gemaakt te worden voor inpassing in de bedrijfsvoering wat ook past bij de wensen en doelen van de veehouder.

- Er dient geïnvesteerd in het opstellen van een bedrijfsspecifiek plan, in plantmateriaal en aanplant. Mogelijk kan een deel van kosten worden betaald uit subsidies.

- Het duurt een aantal jaren voordat de voederbomen voldoende gegroeid zijn om te profiteren van de voordelen, en voederbomen kunnen via schaduwwerking zorgen voor een mindere grasgroei rondom de voederbomen.

\section{Zorgen voor een klimaatbestendig grasland}

In dit onderzoek lag de focus op de effecten van hittestress op de koeien. De gevolgen van (langdurige) hittestress op het grasland kunnen echter wel eens veel groter zijn dan de effecten op de koeien zelf. Hittestress bij gras leidt tot lagere opbrengsten van het grasland en bij verminderde grasproductie duurt de hergroei aanzienlijk langer voordat er geweid kan worden. Hierdoor gaat de rotatieduur voor omweiden omhoog waardoor minder percelen overblijven voor ruwvoederwinning. Ook de smakelijkheid en voederwaarde kan afnemen wat negatieve effecten op melkproductie en gezondheid kan hebben. Bij langdurige warme periodes met weinig regenval (zoals in 1976 of in 2018) kan het zelfs betekenen dat de grasgroei nagenoeg tot stilstand komt en koeien wel op stal gezet moeten worden om ze te kunnen voeren omdat er weinig/geen aanbod van vers gras meer is. De winterkuilvoorraad wordt dan al in de zomer aangebroken wat een forse kostenpost kan inhouden. Richting de toekomst zal daarom een klimaatbestendig grasland nodig zijn om voldoende ruwvoer van eigen land te kunnen blijven oogsten. Mogelijkheden om het grasland meer klimaatbestendig te maken zijn door te zorgen voor een grotere variëteit aan planten in het grasland, zoals bijvoorbeeld door het grassenbestand uit te breiden met droogtetolerante, diep wortelende grassoorten en kruiden. Ook is het belangrijk om verdichtingen in de ondergrond te verhelpen en te voorkomen, zodat wortels dieper kunnen komen. 


\subsection{Voorkomen van (lokale) klimaatverandering}

Een maatregel met een langetermijneffect is het tegengaan van klimaatverandering door vermindering van de $\mathrm{CO}_{2}$-footprint, zorgen voor opslag van $\mathrm{CO}_{2}$ in de bodem via koolstofvastlegging door het verhogen van het organische stofgehalte (bijvoorbeeld via permanent grasland), en verhoging van de duurzame energieproductie.

Men kan de effecten van klimaatverandering op lokaal niveau (deels) verminderen door inzet van (oude of herstelde) landschapselementen zodat beter kan worden omgegaan met veranderlijker en extremer weer. Mogelijkheden waar men aan kan denken zijn het meer vocht vasthouden in het landschap (waterberging, meer groen, bomen), gebruik te maken van reliëf in landschappen (bijv. dijk langs rivier met bomen), zorgen voor een grotere diversiteit aan planten/gewassen zodat tijdens warme en/of droge perioden er voldoende aanbod van ruwvoer is. 


\section{$6 \quad$ Kennishiaten}

Uit de resultaten van het uitgevoerde literatuuronderzoek en de workshop zijn de volgende kennishiaten t.a.v. van hittestress voor de Nederlandse melkveehouderij naar voren gekomen.

\section{Hittestress indicatoren}

- Er is nog geen standaard formule beschikbaar om de THI voor Nederlandse klimaatomstandigheden te berekenen.

- Onduidelijk is of temperatuur en luchtvochtigheid voldoende zijn als indicator of dat zonneinstraling en/of windsnelheid ook meegenomen dienen te worden om een indicator met goede herhaalbaarheid en precisie te krijgen voor Nederlandse omstandigheden.

- Er zijn nog geen goede drempelwaarden voor hittestress onder Nederlandse omstandigheden vastgesteld, omdat er geen eenduidig beeld is vanaf welke drempelwaarde negatieve effecten optreden.

\section{Melkproductie}

- Gevolgen van hittestress op de melkproductie in de volgende lactatie van droge koeien en op de melkproductie van de nakomelingen.

- Voor zover bekend is er nog geen onderzoek uitgevoerd naar de oorzaak waarom koeien van hetzelfde ras met dezelfde dagelijkse melkproductie verschillend reageren op hittestress.

- Onduidelijk is of de daling in melkproductie tijdens warme perioden alleen maar een tijdelijke dip betreft of dat de melkproductie na een (ernstige) hittestress periode niet meer geheel op het oude productieniveau terugkomt. Hiermee samenhangend speelt de vraag in welke mate rantsoenaanpassingen werkelijk nodig zijn om de productie op peil te houden, waarbij waarschijnlijk onderscheid dient te worden gemaakt tussen een korte periode (bijv. 1 à 2 dagen) en een lange periode (bijv. $\geq 7$ dagen).

\section{Melksamenstelling}

- Het effect van hittestress op de melksamenstelling is vooral onderzocht voor het vet- en eiwitgehalte. Naar overige aspecten van de melksamenstelling is geen of weinig onderzoek gedaan.

\section{Celgetal}

- Uit de literatuur bleek vooralsnog geen duidelijke relatie tussen een verhoogd celgetal tijdens de zomer periode en het optreden van klinische mastitis. Hoe de relatie dan ligt tussen een hoog celgetal in warme perioden en (sub)klinische mastitis vraagt nadere opheldering.

\section{Gezondheid}

- Naar de relatie tussen hittestress en klauwgezondheid op langere termijn is geen onderzoek gedaan.

- Naar de relatie tussen hittestress en gezondheidsproblemen (o.a. klinische mastitis) op de langere termijn in gematigde klimaatstreken blijkt geen onderzoek te zijn gedaan.

- Onderzoek naar hittestress en fysiologische veranderingen (bijv. het bicarbonaat gehalte in het bloed) in de koe is in gematigde klimaatstreken nog weinig onderzoek gedaan.

- Onduidelijk is hoe het adaptief vermogen van koeien bij hittestress ingeschat kan worden.

- In welke mate het management van droge koeien en transitiekoeien tijdens warme perioden aangepast dient te worden is onduidelijk.

- Onduidelijk is of er effect van hittestress op de levensduur van koeien is.

\section{Vruchtbaarheid \& fokkerij}

- $\mathrm{Er}$ is in gematigde klimaatstreken geen onderzoek te zijn verricht naar de relatie tussen hittestress en negatieve effecten op het embryo.

- Nader onderzoek naar de relatie tussen weerdata en vruchtbaarheid zal nodig zijn om effecten van hittestress op de stierprestaties onder Nederlandse omstandigheden te kunnen identificeren.

- Wat zijn de gevolgen van hittestress op de opfokresultaten van jongvee? 


\section{Gedrag}

- Naar het effect van hittestress op gedrag is vooral onderzoek gedaan in combinatie met een vorm van schaduwverstrekking.

- Een onderzoeksvraag die een rol speelt bij gedrag is hoe je de negatieve effecten van hittestress op welzijnskenmerken meet. En wanneer gaat een natuurlijke aanpassingsreactie van koeien (gedragsmatig, fysiologisch) bij warmte over in een situatie die schadelijk en belastend is voor het dier, en die gepaard gaat met ongerief?

\section{Voeding \& water}

- $\mathrm{Er}$ is voor zover bekend geen onderzoek in gematigde streken gedaan naar de relatie tussen ruwvoer opname i.r.t. de eigen warmteproductie en hittestress. In theorie zou met name de ruwvoeropname dalen tijdens warme dagen, omdat het verteren van ruwvoer voor meer warmteproductie zorgt, en in verhouding stijgt de krachtvoeropname dan. Deze verschuiving van ruwvoer naar krachtvoer kan tot pensverzuring leiden wat vervolgens weer tot andere gezondheidsproblemen kan leiden zoals afname van de klauwgezondheid.

- Voor zover kon worden nagegaan in de literatuur is er geen onderzoek gedaan naar de relatie tussen wateropname, melkproductie, melksamenstelling en celgetal tijdens perioden van hittestress in gematigde klimaatstreken.

- Vanaf welke temperatuur/THI zijn rantsoenaanpassingen zinvol zijn en welke aanpassingen sorteren daadwerkelijk effect?

\section{Schaduwverstrekking en koelen}

- Management van schaduwverstrekking: benodigde oppervlakte schaduw is om een kudde koeien effectief schaduw te kunnen verstrekken, welke vorm (bomen/schaduwdoek), vanaf welke temperatuur/THI inzetten in de bedrijfsvoering, etc.

- Hoe kunnen bomen en/of zonnepanelen zodanig ingepast worden de bedrijfsvoering zodanig dat voldoende schaduwwerking wordt gecreëerd en de nadelen worden beperkt?

- Onduidelijk is wat effectieve vormen van koeling voor koeien zijn en waar men de koeien het beste kan koelen, zowel de plek in de wei/kavelpad als bij de koe zelf (uier, rug, kop, etc.).

- Inpassing van voederbomen in het rantsoen en de bedrijfsvoering vraagt verder onderzoek.

\section{Monitoring tools}

- Aanvullende ontwikkeling is nodig om koesensoren in te kunnen zetten als 'early warning' systeem voor het optreden van negatieve effecten van hittestress. Een combinatie met weersvoorspelling ligt voor de hand om tijdige waarschuwingen te kunnen geven zodat een veehouder tijdig aanpassingen kan doorvoeren in de bedrijfsvoering kan doorvoeren.

- Mogelijk kunnen koesensoren worden gebruikt om koeien te identificeren die beter bestand zijn c.q. groter adaptief vermogen tegen hittestress dan andere koeien.

\section{Weide- en veemanagement}

Rondom het aanpassen van het vee- en weidemanagement spelen nog verschillende vragen zoals:

- Op welke tijden en onder welke omstandigheden kan men het beste opstallen/weiden?

- Welke factoren zijn van invloed van koe om te kiezen voor verblijf in de wei of op stal?

- Dient er onderscheid gemaakt te worden tussen koeien (bijv. laag- vs. hoogproductief)?

- Zijn er aanpassingen nodig aan het beweidingsysteem zoals bijvoorbeeld vaker maar kleinere oppervlakten aanbieden i.p.v. minder vaak omweiden op grotere oppervlakten?

- Zijn aanpassingen nodig bij het management van jongvee, droge en transitiekoeien?

\section{Klimaatbestendig grasland}

- Met welke grassoorten en/of kruiden kan het grasland worden verbeterd in Nederland om te zorgen dat tijdens warme (en natte) perioden het grasland voldoende in productie blijft? 


\section{$7 \quad$ Discussie}

\section{Temperatuur Luchtvochtigheids Index}

De Temperatuur Luchtvochtigheids Index (THI) is een maat voor hittestress die makkelijk valt te berekenen. Er komen echter verschillende variaties voor van de formule voor berekening van de THI waarbij onderzoekers andere coëfficiënten gebruiken voor de berekening van de THI. Dit bemoeilijkt het onderling vergelijken van onderzoeksresultaten en de interpretatie van de onderzoeksdata wat vervolgens ook de vertaling naar bruikbare drempelwaarden voor de praktijk bemoeilijkt. Bohmanova et al. (2007) concluderen dat verschillende THI-indexen variëren in de mate waarin ze in staat zijn om hittestress te detecteren. Indexen met een groter gewicht op relatieve luchtvochtigheid lijken meer geschikt voor vochtige klimaten, terwijl indexen met een groter gewicht op temperatuur meer geschikt lijken voor droge klimaten. Ook al zou er één index zijn voor de mate van hittestress, dan nog blijft er variatie aangezien de drempelwaarden waarop hittestress optreedt o.a. blijkt af te hangen van de hoogte van de dagelijkse melkproductie, het ras en het bedrijf (André et al., 2011; Bernabucci et al., 2014; Bryant et al., 2007; Hogeveen et al., 2001).

\section{Lange termijn gevolgen en integraliteit}

Ervaringen uit de praktijk geven aan dat na de zomer er een toename van problemen wordt ervaren zoals meer klauwproblemen, lagere melkproductie en slechtere vruchtbaarheid. Al snel wordt dan de link gemaakt met na-ijl effecten van hittestress van de koeien tijdens de zomermaanden. Echter, warme zomerse condities hebben niet alleen een effect op de koe, maar ook op de grasgroei en kwaliteit, smakelijkheid en kwaliteit van het ruwvoer en mengvoer, en aanwezigheid en groei van ziekteverwekkers in de stal. Zo is de VEM-waarde van vers gras lager tijdens de zomermaanden en zijn er seizoensverschillen in mineralengehalten van vers gras (Pellikaan, 2017; Pinxterhuis et al., 1997). In de zomermaanden blijken de gehalten aan spoorelementen in de melk lager te zijn dan in de stalperiode (GD, 2018b). De temperatuur in de voersilo loopt tijdens warme periodes snel op. Bij temperaturen van rond de $30^{\circ} \mathrm{C}$ naar meer dan $60^{\circ} \mathrm{C}$. De afwisseling van warmte met koude zorgt sneller voor condensvorming in de silo waardoor de kans op schimmelgroei toeneemt en de voerkwaliteit negatief wordt beïnvloed (Agrifirm, 2017). Dat de temperatuur in een voersilo zeer hoog kan worden blijkt wel uit een geval waar broei ontstond in een krachtvoersilo en een temperatuur van ruim $150^{\circ} \mathrm{C}$ werd gemeten (Anonymous, 2018). In het derde kwartaal blijken meer klauwproblemen voor te komen (GD, 2018a), maar tegelijkertijd blijkt ook dat veehouders kansen laten liggen om via voeding klauwproblemen te voorkomen (GD, 2018c). Ook zijn er in het derde kwartaal meer koeien die afkalven en bij nieuwmelkte koeien treedt meer klinische mastitis op (Olde Riekerink et al., 2007). Bij lange termijn gevolgen is het daarom zaak om verder te kijken dan alleen hittestress als oorzaak, en ook andere aspecten van de bedrijfsvoering in ogenschouw te nemen om de oorzaken van slechtere resultaten in het najaar te achterhalen.

\section{Hittestress in de stal}

De uitgevoerde verkennende studie was gericht op hittestress bij weidegang, echter hittestress treedt ook op in de stal. Ook in de stal wordt bij temperaturen boven de $20^{\circ} \mathrm{C}$ een afname in melkproductie waargenomen afhankelijk van de hoogte van de temperatuur en de duur van de temperatuur boven de $20^{\circ} \mathrm{C}$ (Herbut et al., 2018). Ook verandert het gedrag van koeien in een stalomgeving tijdens een warme periode. Bij een toenemende THI neemt de ligtijd van de koeien af, daalt de activiteit en gaan koeien meer op de mestgang liggen (Herbut en Angrecka, 2018). Uit een analyse van Duitse melkveestallen blijkt dat zowel het klimaat in nieuwe stallen als oude stallen te wensen overlaat, waarbij onderhoud zoals het schoonhouden van de ventilatoren voor een goede werking ook een aandachtspunt is (Löbel et al., 2018). Het grote verschil tussen de weide en de stal i.r.t. hittestress is dat de koeien in de stal al in de schaduw staan en zo tegen de invloed van zonnestraling worden beschermd. Echter, dit voordeel geldt alleen ten tijde dat de zon schijnt. Aangezien het buiten sneller afkoelt dan binnen heeft de weide dan 's nachts weer een voordeel boven de stal. Uit resultaten bij een AMS blijken koeien tijdens een warme periode tussen 10 en 17 uur minder tijd door te brengen in de wei. Verder lieten de resultaten zien, dat de koeien het overgrote deel $(>80 \%)$ van de ligtijd doorbrachten op de wei als zij toegang tot de wei hadden (Ketelaar-De Lauwere et al., 1999). Waar koeien het liefst verblijven hangt niet alleen van het weer af, maar ook van verschillende andere 
factoren zoals o.a. uitvoering van ligboxen en ligbed, tijdstip van bijvoeren in de stal, kwaliteit van het voer in de stal, hoeveelheid en kwaliteit van het gras in de wei, drinkwatervoorzieningen in stal en wei, kwaliteit van het kavelpad en ook dierfactoren zoals hoogte van melkproductie, verschillen tussen koeien en of koeien als jongvee zijn geweid spelen een rol zoals resultaten van Charlton et al. (2013); Charlton et al. (2011a); Charlton et al. (2011b) onder meer laten zien.

\section{Lange termijneffecten}

De onderzoeken die zijn uitgevoerd naar de effecten van hittestress op melkkoeien in gematigde streken hebben bijna uitsluitend gekeken naar de directe effecten van hittestress op korte termijn zoals melkproductie, lichaamstemperatuur en gedrag en in beperkte mate naar vruchtbaarheid en gezondheid, terwijl uit ervaringen in de praktijk wijzen op dat er ook sprake is van effecten op de lange termijn zoals op de klauwgezondheid. Voor zover bekend zijn er geen studies onder gematigde klimaatcondities gedaan waarbij is gekeken naar de effecten op de lange termijn en op het nageslacht. Daarentegen zijn wel verschillende onderzoeken uitgevoerd naar de effecten van hittestress op de lange termijn onder vochtige subtropische klimaatomstandigheden. In deze onderzoeken werd onderzocht wat het effect van koelen (ventilatoren i.c.m. sprinklers) in een ligboxenstal bij hoge temperaturen was. $\mathrm{Bij}$ een temperatuur boven de $21,1^{\circ} \mathrm{C}$ gingen de ventilatoren en sprinklers $(1,5 \mathrm{~min}$ per 6-min interval) aan. De volgende effecten werden o.a. gevonden:

- Koeien die tijdens de droogstand werden gekoeld hadden een hogere drogestof opname (10,6 vs. $8,9 \mathrm{~kg} / \mathrm{d})$, een grotere melkproductie in de volgende lactatie $(33,9 \mathrm{~kg} / \mathrm{d}$ vs. $28,9 \mathrm{~kg} / \mathrm{d} \Rightarrow 14,7 \%$ verschil) maar een lager eiwitgehalte (2,87 vs. 3,01\%) (Tao et al., 2011).

- Kalveren van koeien die waren gekoeld tijdens de droogstand hadden in 4 van de 5 onderzoeken een hoger geboortegewicht (Monteiro et al., 2016a; Monteiro et al., 2014; Monteiro et al., 2016b; Tao et al., 2014; Tao et al., 2012).

- In drie onderzoeken was bij het spenen van de kalveren van koeien, die gekoeld waren tijdens de droogstand, een hoger speengewicht. Echter in één van de drie onderzoeken was het verschil niet significant (Monteiro et al., 2016a; Tao et al., 2014; Tao et al., 2012).

- Kalveren van koeien, die waren gekoeld tijdens de droogstand, hadden hogere hematocriet waarden welke of net of net niet significant verschillend waren (Guo et al., 2016; Monteiro et al., 2016a; Tao et al., 2012).

- Vaarzen afkomstig van koeien die tijdens de droogstand gekoeld waren hadden een hogere melkproductie tijdens de eerste 35 weken van de lactatie ( 31,9 vs. $26,8 \mathrm{~kg} / \mathrm{d} \Rightarrow 16 \%$ verschil) (Monteiro et al., 2016b).

Het is de vraag in hoeverre de resultaten uit deze onderzoeken 1-op-1 vergelijkbare effecten geven in gematigde klimaatstreken, aangezien er in de subtropen sprake is van een hogere en langdurige mate van hittestress dan in gematigde klimaatstreken. In gematigde klimaatstreken heb je meer afwisseling van zomerse/tropische dagen met koele dagen en tevens is er de afwisseling van zomerse/tropische temperaturen overdag met nachten waar de temperatuur onder de $20^{\circ} \mathrm{C}$ uitkomt. Hierdoor zullen koeien zich naar verwachting beter kunnen herstellen van de warmte dan bij langdurige tropische dagen gecombineerd met warme nachten. De effecten in gematigde klimaatstreken zullen dus naar verwachting kleiner zijn. Als dit effect een derde is van het effect in subtropische klimaten dan zou dit een negatief effect hebben van circa $5 \%$ op de melkproductie in de volgende lactatie van koeien die droog staan tijdens een hittestressperiode. Bij een melkproductie van $8.500 \mathrm{~kg}$ komt dit neer op een $425 \mathrm{~kg}$ lagere melkproductie. Bij een melkprijs van een $€ 34,50$ per $100 \mathrm{~kg}$ melk en toegerekende voer- en veekosten van respectievelijk $€ 8,33$ en $€ 2,82$ per $100 \mathrm{~kg}$ melk (Blanken et al., 2017) wordt een saldo gerealiseerd van $€ 23,25$ per $100 \mathrm{~kg}$ melk gerealiseerd. Een verminderde melkopbrengst van $425 \mathrm{~kg}$ bij leidt derhalve tot een verminderd saldo van €99. Als $10 \%$ van de droge koeien in een jaar te maken krijgt met te veel dagen van te hoge hittestress, dan komt dit bij een melkveebedrijf met 100 koeien uit op bijna $€ 1.000$. Als er uit deze koeien $50 \%$ vaarskalveren geboren worden waarvan $60 \%$ uiteindelijk in productie komen, dan betreft dit 3 vaarzen die mogelijk een negatief effect ervaren als gevolg van hittestress van de moederkoe. Als deze vaarzen ook een $5 \%$ lagere melkproductie hebben in de eerste lactatie dan betekent dit aanvullend nog eens $€ 300$ lager saldo, en totaal dan zou een vermindering van $€ 1300$ betekenen op het saldo van het bedrijf. 


\section{Conclusies en aanbevelingen}

\subsection{Conclusies}

De belangrijkste resultaten van het uitgevoerde literatuuronderzoek naar de effecten van hittestress op de melkproductie, gezondheid en welzijn bij melkvee in gematigde klimaatstreken zijn:

- De Temperatuur Luchtvochtigheid Index (THI), gebaseerd temperatuur en luchtvochtigheid, is de meest gebruikte hittestress indicator.

- Hittestress zorgt voor een daling in melkproductie, waarbij dalingen tot $-12 \%$ zijn vastgesteld. Hoe hoger de THI, des te groter de daling in melkproductie was. Vanaf welke THI een daling optreedt blijkt te verschillen tussen bedrijven. De daling in melkproductie is het grootst bij melkkoeien met de hoogste dagelijkse melkproductie en het laagst voor koeien met de laagste dagproductie.

- Hittestress heeft een negatief op het vet- en eiwitgehalte in de melk, waarbij dalingen tot $-16 \%$ en $-17 \%$ respectievelijk zijn gerapporteerd. Hoe hoger de THI, des te groter de daling in gehalte was.

- Tijdens warme perioden is het tankmelkcelgetal het hoogst, waarbij er geen verschil bleek te zijn tussen bedrijven die onbeperkt weiden, beperkt weiden of jaarrond opstallen. Koeien met de hoogste dagelijkse melkproductie vertoonde de grootste stijging in celgetal tijdens warme perioden. Oudere koeien en laat-lactatie koeien hadden de grootste kans op een verhoogd celgetal.

- De incidentie van klinische mastitis blijkt het hoogst te zijn in de periode december-januari, behalve voor Streptococcus uberis die het hoogst blijkt te zijn in augustus. Een kleine piek in de incidentie van klinische mastitis blijkt in tweede helft van juli op te treden, vooral bij bedrijven met een hoog tankmelkcelgetal.

- Bij transitiekoeien blijkt in de zomer de conditiescore al voor het afkalven te dalen, terwijl dit in het voorjaar pas na het afkalven gebeurd. Ook is er sprake te van oxidatieve stress bij transitiekoeien bij middelmatige hittestress en het optreden van een hogere vetaccumulatie bij koeien die in zomer afkalven.

- De $\mathrm{pH}$ in de pens is lager bij hogere temperaturen. Ook lijkt er sprake te zijn van een lagere ammoniak- en melkzuurconcentratie in de pens bij hogere temperaturen.

- Er is een negatief effect op het drachtigheidspercentage, waarbij de afname het sterkst is bij hoogproductieve koeien. Het effect is groter bij een langdurige periode van hittestress dan bij een kortdurende periode.

- Er vindt een aanpassing in gedrag plaats. Zo zijn de koeien bij een AMS overdag meer in de stal, en s 'nachts meer in de wei.

- Vanaf een THI van 76 zijn metabolische verschuivingen van vet naar koolhydraten benutting vastgesteld.

- Het verstrekken van schaduw leidt tot een toename in melkproductie, een lagere lichaams- en vaginale temperatuur, een lagere ademhalingsfrequentie, aanpassing in gedrag, hogere krachtvoeropname en wordt minder tijd bij de waterbak doorgebracht.

Het aantal warme $\left(T>20^{\circ} \mathrm{C}\right)$, zomerse $\left(T>25^{\circ} \mathrm{C}\right)$, tropische $\left(T>30^{\circ} \mathrm{C}\right)$ dat een melkveebedrijf in gemiddeld jaar mee te maken hangt af de locatie van het bedrijf. Het zuidoosten heeft de meeste warme dagen en in het noordwesten en langs de kust het minste aantal dagen. Daarentegen het aantal zonnige dagen en de relatieve luchtvochtigheid het hoogst in de kustregio en neemt het landinwaarts af. De relatieve luchtvochtigheid is het laagst in de zomermaanden. De windsnelheid is het hoogst in de kustregio en neemt landinwaarts af.

De economische gevolgen van hittestress zijn sterk bedrijfsafhankelijk vanwege de locatie van het bedrijf in Nederland en de hoogte van de melkproductie. Indicatieve berekeningen laten voor een melkveebedrijf met 100 koeien een kostenpost zien van circa $€ 3.000$ bij weinig warme dagen, oplopend naar een kostenpost van circa $€ 5.600$ bij veel warme dagen. 
Uit een workshop met mensen uit de melkveesector aangevuld met informatie uit andere bronnen zijn volgende oplossingsrichtingen benoemd:

- Aanpassen van het weidemanagement (bijv. 's avonds en 's nachts weiden)

- Benutten van de aanwezige variatie in de koppel koeien (bijv. laagproductieve koeien weiden)

- Vermijden van stress tijdens perioden van hittestress

- Inzetten van monitoringtools

- Aanpassen van de voeding

- Aanpassen van de inseminatiestrategie

- Aanpassen van het fokdoel

- Plaatsen van schaduwdoeken

- Gebruik van verplaatsbare schaduwdoeken

- Plekgewijs zonnepanelen in de wei plaatsen

- Koelen van koeien

- Verstrekken van schaduw via landschapsbomen

- Verstrekken van schaduw via voederbomen

- Zorgen voor een klimaatbestendig grasland

- Voorkomen van (lokale) klimaatverandering

Uit de resultaten van het uitgevoerde literatuuronderzoek en de workshop zijn de verschillende kennishiaten naar voren gekomen. De belangrijkste kennishiaten liggen op het gebied van het vaststellen van een goede hittestress indicator met drempelwaarden voor de Nederlandse melkveehouderij; ophelderen van lange termijn relaties tussen hittestress en melkproductie, gezondheid, en opfokresultaten van jongvee; fysiologische veranderingen die optreden a.g.v. hittestress; natuurlijk aanpassingsvermogen en adaptatie van koeien; effecten van rantsoenwijzingen; effecten van wijzigingen van vee- en weidemanagement; management van jongvee, droge en transitiekoeien tijdens warme; en klimaatbestendig grasland.

\subsection{Aanbevelingen}

Uit de huidige verkennende studie is naar voren gekomen dat over de directe gevolgen van hittestress in gematigde klimaatstreken het nodige bekend is. Naar de indirecte gevolgen op langere termijn is weinig onderzoek gedaan. Aandachtspunten voor onderzoek naar langere termijn effecten zijn met name vruchtbaarheid, gezondheid en de effecten van hittestress tijdens droogstand en transitie op de volgende lactatie en kalfprestaties.

Aangezien de praktijk jaarlijks in het najaar te kampen heeft met meer problemen, verdient het aanbeveling om nader onderzoek te doen naar de onderliggende oorzaken van de zogenoemde (na)zomerdip. Dit vereist een integrale aanpak om de werkelijke oorzaken van de problemen boven tafel te krijgen. Naast het effect van hittestress op de koe dienen ook andere bedrijfsaspecten onder de loep te worden genomen zoals o.a. opslag en kwaliteit van voeding, drinkwaterkwaliteit, weidemanagement en bedrijfshygiëne. Hierbij zal ook de fysiologische achtergrond in ogenschouw dienen te worden om de onderliggende relaties te kunnen begrijpen.

Gezien de verwachte klimaatveranderingen zal de koe van de toekomst over een groter adaptief vermogen dienen te beschikken dan de huidige koe. Het uitvoeren van onderzoek naar de natuurlijke aanpassingsreactie van koeien (gedragsmatig en fysiologisch) bij warme, zomerse condities is zinvol om te bepalen wanneer er sprake is van een situatie die schadelijk en belastend is voor het dier, en die gepaard gaat met ongerief. Op basis hiervan kan het adaptief vermogen van koeien gaan worden ingeschat om zo te kunnen aangeven in welke mate koeien in staat zullen zijn om te gaan met veranderende weersomstandigheden en welke maatregelen veehouders kunnen nemen om daar op in te spelen.

Voor de praktijk spelen met name vragen rondom aanpassingen in het vee- en weidemanagement, en wijzigingen in het rantsoen, en schaduwverstrekking tijdens warme perioden. Praktijkonderzoek naar deze aspecten geeft veehouders meer inzicht in welke maatregelen effectief zijn, hoe ze dit kunnen integreren in hun bedrijfsvoering en wat de verwachte resultaten van deze maatregelen zijn. 


\section{Literatuur}

Abeni, F., en A. Galli. 2017. Monitoring cow activity and rumination time for an early detection of heat stress in dairy cow. International Journal of Biometeorology 61 (3):417-425. doi 10.1007/s00484-0161222-z

Aggarwal, A., en R. Upadhyay. 2013. Heat stress and animal productivity. Springer, New Delhi.

Agrifirm. 2017. Laat de warmte uw voerkwaliteit niet beïnvloeden. https://www.agrifirm.nl/nieuws/laat-dewarmte-uw-voerkwaliteit-niet-beinvloeden/. Accessed 30 juli 2018.

André, G., B. Engel, P. B. M. Berentsen, T. Vellinga, en A. G. J. M. Oude Lansink. 2011. Quantifying the effect of heat stress on daily milk yield and monitoring dynamic changes using an adaptive dynamic model. Journal of Dairy Science 94 (9):4502-4513. doi 10.3168/jds.2010-4139

Anonymous. 2018. Broei in een krachtvoersilo aan de Westerzanden in Hellum. https://www.112wagenborgen.eu/index.php/2018/07/08/broei-in-een-krachtvoersilo-aan-dewesterzanden-in-hellum/. Accessed 8 juli 20182018.

Bandaranayaka, D. D., en C. W. Holmes. 1976. Changes in the composition of milk and rumen contents in cows exposed to a high ambient temperature with controlled feeding. Tropical Animal Health and Production 8 (1):38-46. doi 10.1007/bf02383364

Basiricò, L., U. Bernabucci, P. Morera, N. Lacetera, en A. Nardone. 2009. Gene expression and protein secretion of apolipoprotein B100 (ApoB100) in transition dairy cows under hot or thermoneutral environments. Italian Journal of Animal Science 8 (SUPPL. 2):592-594.

Bernabucci, U., S. Biffani, L. Buggiotti, A. Vitali, N. Lacetera, en A. Nardone. 2014. The effects of heat stress in Italian Holstein dairy cattle. Journal of Dairy Science 97 (1):471-486. doi 10.3168/jds.2013-6611

Bernabucci, U., N. Lacetera, B. Ronchi, en A. Nardone. 2002. Effects of the hot season on milk protein fractions in Holstein cows. Animal Research 51 (1):25-33.

Bertocchi, L., A. Vitali, N. Lacetera, A. Nardone, G. Varisco, en U. Bernabucci. 2014. Seasonal variations in the composition of Holstein cow's milk and temperature-humidity index relationship. Animal 8 (4):667-674. doi 10.1017/s1751731114000032

Bierma, M. P. R., K. Frankena, H. Hogeveen, J. H. M. Metz, en E. N. Stassen. 2006. Beslissingsondersteunende studie voor de aanpak van kreupelheid en klauwaandoeningen op melkveebedrijven. Pages 90Wageningen University, Wageningen.

Biffani, S., U. Bernabucci, A. Vitali, N. Lacetera, en A. Nardone. 2016. Short communication: Effect of heat stress on nonreturn rate of Italian Holstein cows. Journal of Dairy Science 99 (7):5837-5843. doi $10.3168 /$ jds. 2015-10491

Blanken, K., F. de Buisonje, A. Evers, W. Ouweltjes, J. Verkaik, I. Vermeij, en H. Wemmenhove. 2017. Kwantitatieve Informatie Veehouderij 2017-2018. Wageningen Livestock Research, Wageningen.

Bohmanova, J., I. Misztal, en J. B. Cole. 2007. Temperature-humidity indices as indicators of milk production losses due to heat stress. Journal of Dairy Science 90 (4):1947-1956. doi 10.3168/jds.2006-513

Brügemann, K., E. Gernand, U. K. Von Borste, en S. König. 2012. Defining and evaluating heat stress thresholds in different dairy cow production systems. Archiv fur Tierzucht 55 (1):13-24.

Brügemann, K., E. Gernand, U. U. von Borstel, en S. König. 2013. Application of random regression models to infer the genetic background and phenotypic trajectory of binary conception rate by alterations of temperature $\times$ humidity indices. Livestock Science 157 (2-3):389-396. doi 10.1016/j.livsci.2013.08.009

Bryant, J. R., N. López-Villalobos, J. E. Pryce, C. W. Holmes, en D. L. Johnson. 2007. Quantifying the effect of thermal environment on production traits in three breeds of dairy cattle in New Zealand. New Zealand Journal of Agricultural Research 50 (3):327-338. doi 10.1080/00288230709510301

Calamari, L., F. Petrera, L. Stefanini, en F. Abeni. 2013. Effects of different feeding time and frequency on metabolic conditions and milk production in heat-stressed dairy cows. International Journal of Biometeorology 57 (5):785-796. doi 10.1007/s00484-012-0607-x

Charlton, G. L., S. Rutter, M. East, en L. A. Sinclair. 2013. The motivation of dairy cows for access to pasture. Journal of Dairy Science 96 (7):4387-4396. doi 10.3168/jds.2012-6421

Charlton, G. L., S. M. Rutter, M. East, en L. A. Sinclair. 2011a. Effects of providing total mixed rations indoors and on pasture on the behavior of lactating dairy cattle and their preference to be indoors or on pasture. Journal of Dairy Science 94 (8):3875-3884. doi 10.3168/jds.2011-4172

Charlton, G. L., S. M. Rutter, M. East, en L. A. Sinclair. 2011b. Preference of dairy cows: Indoor cubicle housing with access to a total mixed ration vs. access to pasture. Applied Animal Behaviour Science 130 (1-2):1-9. doi 10.1016/j.applanim.2010.11.018 
Cook, N. B., R. L. Mentink, T. B. Bennett, en K. Burgi. 2007. The effect of heat stress and lameness on time budgets of lactating dairy cows. Journal of Dairy Science 90 (4):1674-1682. doi 10.3168/jds.2006634

Cools, S., P. Bossaert, T. Caluwaerts, M. Hostens, G. Opsomer, en A. de Kruif. 2008. De economische gevolgen van een verlenging van de tussenkalftijd bij hoogproductief melkvee. Vlaams Diergeneeskundig Tijdschrift 77:406-413.

Eslamizad, M., O. Lamp, M. Derno, en B. Kuhla. 2015. The control of short-term feed intake by metabolic oxidation in late-pregnant and early lactating dairy cows exposed to high ambient temperatures. Physiology and Behavior 145:64-70. doi 10.1016/j.physbeh.2015.03.044

Fisher, A. D., N. Roberts, S. J. Bluett, G. A. Verkerk, en L. R. Matthews. 2008. Effects of shade provision on the behaviour, body temperature and milk production of grazing dairy cows during a New Zealand summer. New Zealand Journal of Agricultural Research 51 (2):99-105. doi $10.1080 / 00288230809510439$

GD. 2018a. De link tussen hittestress en klauwaandoeningen. https://www.gddiergezondheid.nl/actueel/nieuws/2018/06/de-link-tussen-hittestress-enklauwaandoeningen. Accessed 27 juli 20182018.

GD. 2018b. Minder of meer mineralen voeren deze zomer? . https://www.gddiergezondheid.nl/actueel/nieuws/2018/06/minder-of-meer-mineralen-voeren-dezezomer. Accessed 30 juli 20182018.

GD. 2018c. Voedingsmaatregelen kans voor klauwgezondheid https://www.gddiergezondheid.nl/actueel/nieuws/2018/02/voedingsmaatregelen-kans-voorklauwgezondheid. Accessed 30 juli 2018.

Gebremedhin, K. G., C. N. Lee, P. E. Hillman, en T. M. Brown-Brandl. 2011. Body temperature and behavioral activities of Four breeds of heifers in shade and full sun. Applied Engineering in Agriculture 27 (6):999-1006.

Gorniak, T., U. Meyer, K. H. Südekum, en S. Dänicke. 2014. Impact of mild heat stress on dry matter intake, milk yield and milk composition in mid-lactation Holstein dairy cows in a temperate climate. Archives of Animal Nutrition 68 (5):358-369. doi 10.1080/1745039x.2014.950451

Guo, J. R., A. P. A. Monteiro, X. S. Weng, B. M. Ahmed, J. Laporta, M. J. Hayen, G. E. Dahl, J. K. Bernard, en S. Tao. 2016. Short communication: Effect of maternal heat stress in late gestation on blood hormones and metabolites of newborn calves. Journal of Dairy Science 99 (8):6804-6807. doi $10.3168 /$ jds.2016-11088

Hammami, H., J. Bormann, N. M'Hamdi, H. H. Montaldo, en N. Gengler. 2013. Evaluation of heat stress effects on production traits and somatic cell score of Holsteins in a temperate environment. Journal of Dairy Science 96 (3):1844-1855. doi 10.3168/jds.2012-5947

Hegen, G. 2018. Persoonlijke mededelingBoerenveearts, Sleen.

Herbut, P., en S. Angrecka. 2018. Relationship between THI level and dairy cows' behaviour during summer period. Italian Journal of Animal Science 17 (1):226-233. doi 10.1080/1828051x.2017.1333892

Herbut, P., S. Angrecka, en D. Godyń. 2018. Effect of the duration of high air temperature on cow's milking performance in moderate climate conditions. Annals of Animal Science 18 (1):195-207. doi 10.1515/aoas-2017-0017

Hill, D. L., en E. Wall. 2014. Dairy cattle in a temperate climate: The effects of weather on milk yield and composition depend on management. Animal 9 (1):138-149. doi 10.1017/s1751731114002456

Hill, D. L., en E. Wall. 2017. Weather influences feed intake and feed efficiency in a temperate climate. Journal of Dairy Science 100 (3):2240-2257. doi 10.3168/jds.2016-11047

Hogenkamp. 2015. Aantal gevallen klinische mastitis modelmatig vast te stellen. Boerderij. doi https://www.boerderij.nl/Rundveehouderij/Nieuws/2015/8/Aantal-gevallen-klinische-mastitismodelmatig-vast-te-stellen-2672551W/

Hogeveen, H. 2015. Belangrijke kengetallen. Wageningen University. doi https://www.slideshare.net/henkhogeveen/economic-farm-figures-and-the-milk-quotum

Hogeveen, H., J. J. Poelarends, O. C. Sampimon, en H. D. Miltenburg. 2001. Heat stress in a mild climate: dutch experiences. Proc. Proceedings of the Dutch-Israeli seminar on robotic milking and heat stress, Wageningen.

Hooijer, G. A. 2018. Persoonlijke mededelingUniversiteit Utrecht, Utrecht.

Kendall, P. E., P. P. Nielsen, J. R. Webster, G. A. Verkerk, R. P. Littlejohn, en L. R. Matthews. 2006. The effects of providing shade to lactating dairy cows in a temperate climate. Livestock Science 103 (12):148-157. doi 10.1016/j.livsci.2006.02.004

Kendall, P. E., G. A. Verkerk, J. R. Webster, en C. B. Tucker. 2007. Sprinklers and shade cool cows and reduce insect-avoidance behavior in pasture-based dairy systems. Journal of Dairy Science 90 (8):3671-3680. doi $10.3168 /$ jds.2006-766

Ketelaar-De Lauwere, C. C., A. H. Ipema, E. N. J. Van Ouwerkerk, M. M. W. B. Hendriks, J. H. M. Metz, J. P. T. M. Noordhuizen, en W. G. P. Schouten. 1999. Voluntary automatic milking in combination with 
grazing of dairy cows: Milking frequency and effects on behaviour. Applied Animal Behaviour Science 64 (2):91-109. doi 10.1016/s0168-1591(99)00027-1

KNMI. 2015. KNMI'14-klimaatscenario's voor Nederland; Leidraad voor professionals in klimaatadaptatie. Pages 34KNMI, De Bilt.

KNMI. 2017. Waarnemingen klimaatveranderingen. https://www.knmi.nl/kennis-endatacentrum/achtergrond/waarnemingen-klimaatveranderingen.

KNMI. 2018. Klimaatatlas - Langjarige gemiddelden 1981-2010.KNMI, De Bilt.

Lambertz, C., C. Sanker, en M. Gauly. 2014. Climatic effects on milk production traits and somatic cell score in lactating Holstein-Friesian cows in different housing systems. Journal of Dairy Science 97 (1):319-329. doi 10.3168/jds.2013-7217

Lamp, O., M. Derno, W. Otten, M. Mielenz, G. Nürnberg, en B. Kuhla. 2015. Metabolic heat stress adaption in transition cows: Differences in macronutrient oxidation between late-gestating and early-lactating German Holstein dairy cows. PLoS ONE 10 (5). doi 10.1371/journal.pone. 0125264

Legrand, A. L., M. A. G. Von keyserlingk, en D. M. Weary. 2009. Preference and usage of pasture versus free-stall housing by lactating dairy cattle. Journal of Dairy Science 92 (8):3651-3658. doi 10.3168/jds.2008-1733

Löbel, J., P. Gütschow, C. Fuchs, en S. Rose-Meierhöfer. 2018. Climate conditions - a status quo at dairy farms in North - East Germany in EurAgEng 2018 conference, Wageningen, the Netherlands.

Luske, B., I. van Meir, A. Altinalmazis Kondylis, S. Roelen, en N. van Eekeren. 2017. Online fodder tree database for Europe. . L. B. I. e. S. Duinboeren ed., Bunnik/Helvoirt.

Mishra, M., F. A. Martz, R. W. Stanley, H. D. Johnson, J. R. Campbell, en E. Hilderbrand. 1970. Effect of diet and ambient temperature-humidity on ruminal $\mathrm{pH}$, oxidation reduction potential, ammonia and lactic acid in lactating cows. Journal of Animal Science 30:1023-1028.

Monteiro, A. P. A., J. R. Guo, X. S. Weng, B. M. Ahmed, M. J. Hayen, G. E. Dahl, J. K. Bernard, en S. Tao. 2016a. Effect of maternal heat stress during the dry period on growth and metabolism of calves. Journal of Dairy Science 99 (5):3896-3907. doi 10.3168/jds.2015-10699

Monteiro, A. P. A., S. Tao, I. M. Thompson, en G. E. Dahl. 2014. Effect of heat stress during late gestation on immune function and growth performance of calves: Isolation of altered colostral and calf factors. Journal of Dairy Science 97 (10):6426-6439. doi 10.3168/jds.2013-7891

Monteiro, A. P. A., S. Tao, I. M. T. Thompson, en G. E. Dahl. 2016b. In utero heat stress decreases calf survival and performance through the first lactation. Journal of Dairy Science 99 (10):8443-8450. doi https://doi.org/10.3168/jds.2016-11072

Nielsen, P. P., en E. Wredle. 2016. It is warm outside today: How temperature affects dairy cows' willingness to be on pasture. Acta Agriculturae Scandinavica A: Animal Sciences 66 (4):215-220. doi 10.1080/09064702.2017.1346701

Olde Riekerink, R. G. M., H. W. Barkema, en H. Stryhn. 2007. The effect of season on somatic cell count and the incidence of clinical mastitis. Journal of Dairy Science 90 (4):1704-1715. doi 10.3168/jds.2006567

Palacio, S., R. Bergeron, S. Lachance, en E. Vasseur. 2015. The effects of providing portable shade at pasture on dairy cow behavior and physiology. Journal of Dairy Science 98 (9):6085-6093. doi $10.3168 /$ jds.2014-8932

Pellikaan, F. 2017. Grasseizoen 2017: lang, maar zonder groeispurt. Veeteelt : magazine van het Koninklijk Nederlands Rundvee Syndicaat NRS (oktober 2): 46 - 47.

Pinxterhuis, I., G. André, en G. A. M. Vervoorn. 1997. Grote verschillen in vers-graskwaliteit binnen bedrijven. Praktijkonderzoek Rundvee, Schapen en Paarden. Praktijkonderzoek 10 (2):20-22.

Porter, R. 2014. Keep 'em cool : tackle heat stress and keep the weight off cows' feet. CowManagement 12 (8):30-31.

Qlip. 2018. Celgetal zet opnieuw stap voorwaarts https://www.qlip.nl/nl/component/tags/tag/celgetal. Accessed 5 maart 2017.

Remmelink, G., K. Blanken, J. van Middelkoop, W. Ouweltjes, en H. Wemmenhove. 2017. Handboek Melkveehouderij 17/18. Wageningen Livestock Research, Wageningen.

Rhoads, M. L., R. P. Rhoads, M. J. VanBaale, R. J. Collier, S. R. Sanders, W. J. Weber, B. A. Crooker, en L. H. Baumgard. 2009. Effects of heat stress and plane of nutrition on lactating Holstein cows: I. Production, metabolism, and aspects of circulating somatotropin. Journal of Dairy Science 92 (5): 1986-1997. doi $10.3168 /$ jds.2008-1641

Rienks, W. A. 2018. Artist impression van pleksgewijze plaatsing van zonnepanelen in de weiROM3D Research, Harfsen.

Roelen, S. 2017. Potential benefits of integrating fodder trees on dairy farms for animal health and welfare: an explorative study. Wageningen University, Wageningen.

Schüller, L., O. Burfeind, en W. Heuwieser. 2015. What is the most effective breeding strategy of dairy cows under short and long term heat stress? 
Schütz, K. E., N. R. Cox, en L. R. Matthews. 2008. How important is shade to dairy cattle? Choice between shade or lying following different levels of lying deprivation. Applied Animal Behaviour Science 114 (3-4):307-318. doi 10.1016/j.applanim.2008.04.001

Schütz, K. E., N. R. Cox, en C. B. Tucker. 2014. A field study of the behavioral and physiological effects of varying amounts of shade for lactating cows at pasture. Journal of Dairy Science 97 (6):3599-3605. doi $10.3168 /$ jds.2013-7649

Schütz, K. E., A. R. Rogers, N. R. Cox, J. R. Webster, en C. B. Tucker. 2011. Dairy cattle prefer shade over sprinklers: Effects on behavior and physiology. Journal of Dairy Science 94 (1):273-283. doi 10.3168/jds.2010-3608

Schütz, K. E., A. R. Rogers, Y. A. Poulouin, N. R. Cox, en C. B. Tucker. 2010. The amount of shade influences the behavior and physiology of dairy cattle. Journal of Dairy Science 93 (1):125-133. doi $10.3168 /$ jds.2009-2416

Tao, S., J. W. Bubolz, B. C. do Amaral, I. M. Thompson, M. J. Hayen, S. E. Johnson, en G. E. Dahl. 2011. Effect of heat stress during the dry period on mammary gland development. Journal of Dairy Science 94 (12):5976-5986. doi 10.3168/jds.2011-4329

Tao, S., A. P. A. Monteiro, M. J. Hayen, en G. E. Dahl. 2014. Short communication: Maternal heat stress during the dry period alters postnatal whole-body insulin response of calves. Journal of Dairy Science 97 (2):897-901. doi 10.3168/jds.2013-7323

Tao, S., A. P. A. Monteiro, I. M. Thompson, M. J. Hayen, en G. E. Dahl. 2012. Effect of late-gestation maternal heat stress on growth and immune function of dairy calves. Journal of Dairy Science 95 (12):7128-7136. doi 10.3168/jds.2012-5697

Tucker, C. B., A. R. Rogers, en K. E. Schütz. 2008. Effect of solar radiation on dairy cattle behaviour, use of shade and body temperature in a pasture-based system. Applied Animal Behaviour Science 109 (24):141-154. doi 10.1016/j.applanim.2007.03.015

Valtorta, S. E., en M. R. Gallardo. 2004. Evaporative cooling for Holstein dairy cows under grazing conditions. International Journal of Biometeorology 48 (4):213-217. doi 10.1007/s00484-003-01969

van Eekeren, N., B. Luske, M. Vonk, en E. Anssems. 2014. Voederbomen in de landbouw - Meer waarde per hectare door multifunctioneel landgebruik. Pages 30Louis Bolk Instituut.

Van Laer, E., C. P. H. Moons, B. Ampe, B. Sonck, L. Vandaele, S. De Campeneere, en F. A. M. Tuyttens. 2015a. Effect of summer conditions and shade on behavioural indicators of thermal discomfort in Holstein dairy and Belgian Blue beef cattle on pasture. Animal 9 (9):1536-1546. doi $10.1017 / \mathrm{s} 1751731115000804$

Van Laer, E., C. P. H. Moons, B. Ampe, B. Sonck, L. Vandaele, en F. Tuyttens. 2014. Effeft of heat load on shade use and panting score in Holstein dairy and Belgian Blue beef cattle on pasture. Proc. Proceedings of the Benelux ISAE conference 2014, Eersel, The Netherlands.

Van Laer, E., F. Tuyttens, L. Vandaele, S. De Campeneere, en B. Sonck. 2015b. Detectie, gevolgen en preventie van hittestress bij rundvee op de weide. Instituut voor Landbouw- en Visserijonderzoek, Merelbeke.

van Soest, F. J. S., I. M. G. A. Santman-Berends, T. J. G. M. Lam, en H. Hogeveen. 2016. Failure and preventive costs of mastitis on Dutch dairy farms. Journal of Dairy Science 99 (10):8365-8374. doi https://doi.org/10.3168/jds.2015-10561

Versteeg, D. 2016. Een fris stalklimaat voor een koele koe : huisvestingsspecialist Egbert Anne Andringa: \&\#8216; veehouders moeten de gevolgen van hittestress niet onderschatten'. Veeteelt : magazine van het Koninklijk Nederlands Rundvee Syndicaat NRS 33 (7):30-35.

Vitali, A., A. Felici, S. Esposito, U. Bernabucci, L. Bertocchi, C. Maresca, A. Nardone, en N. Lacetera. 2015. The effect of heat waves on dairy cow mortality. Journal of Dairy Science 98 (7):4572-4579. doi $10.3168 /$ jds.2015-9331

Vitali, A., M. Segnalini, L. Bertocchi, U. Bernabucci, A. Nardone, en N. Lacetera. 2009. Seasonal pattern of mortality and relationships between mortality and temperature-humidity index in dairy cows. Journal of Dairy Science 92 (8):3781-3790. doi 10.3168/jds.2009-2127

Wheelock, J. B., R. P. Rhoads, M. J. VanBaale, S. R. Sanders, en L. H. Baumgard. 2010. Effects of heat stress on energetic metabolism in lactating Holstein cows. Journal of Dairy Science 93 (2):644-655. doi $10.3168 /$ jds.2009-2295

Wildridge, A., S. G. Garcia, P. Thomson, C. E. F. Clark, E. Jongman, en K. L. Kerrisk. 2016. The impact of a partially shaded laneway on voluntary traffic between pasture and an automatic milking system. Pages 163-168 in Precision Dairy Farming 2016, Leeuwarden, The Netherlands.

Wildridge, A. M., S. C. Garcia, P. C. Thomson, E. C. Jongman, C. E. F. Clark, en K. L. Kerrisk. 2017. The impact of a shaded pre-milking yard on a pasture-based automatic milking system. Animal Production Science 57 (7):1219-1225. doi 10.1071/an16491

Zom, R. 2016. Heat management strategies on dairy farmsWageningen Livestock Research.

Zulovich, J. M. 1998. 20' X 40' Portable cattle shade. Pages 3. U. o. Missouri ed., Columbia, Mo, USA. 


\section{Bijlage 1 Klimaatgegevens per maand}
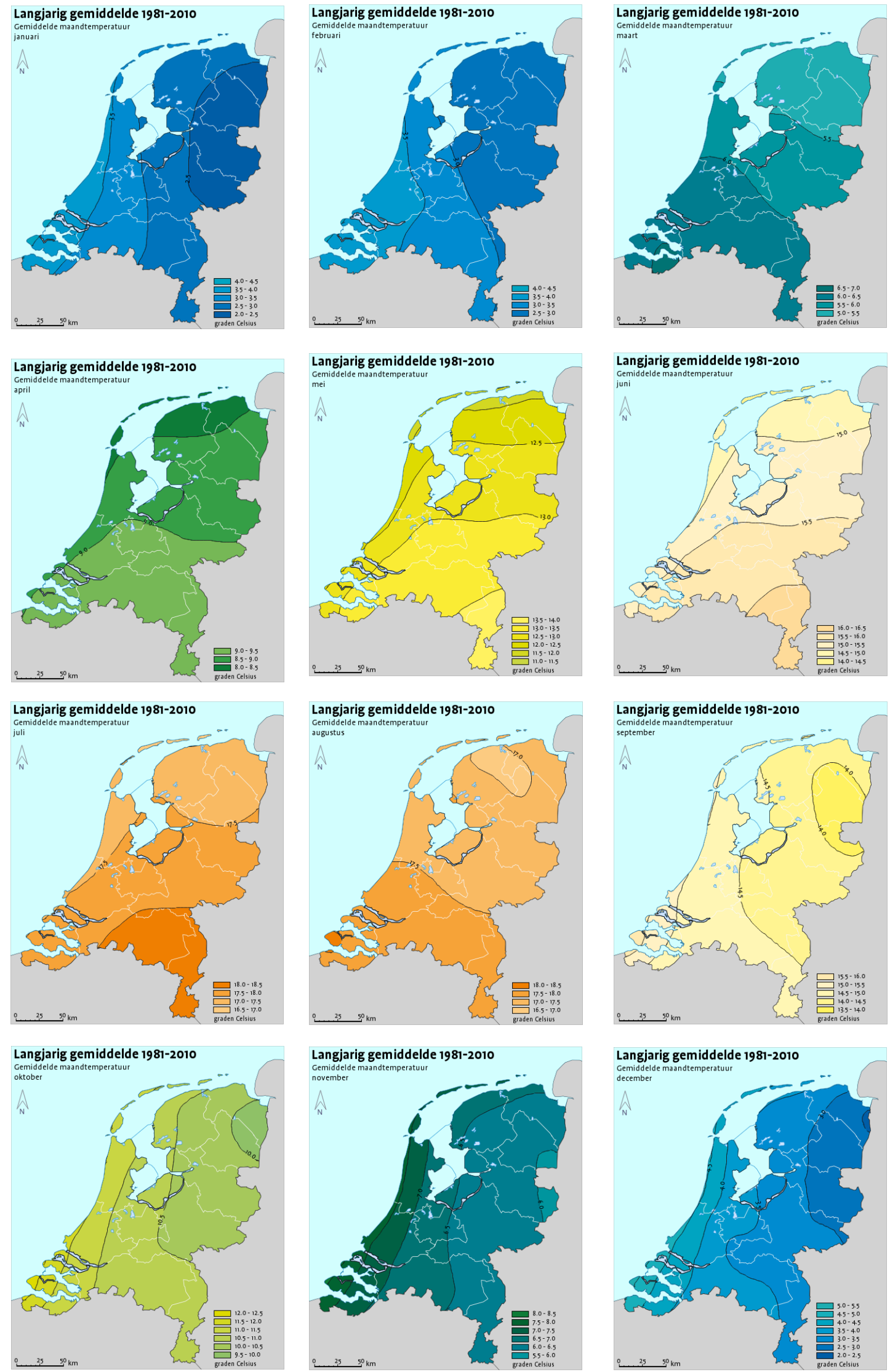

Figur A Gemiddelde maandtemperatur in Nederland. 

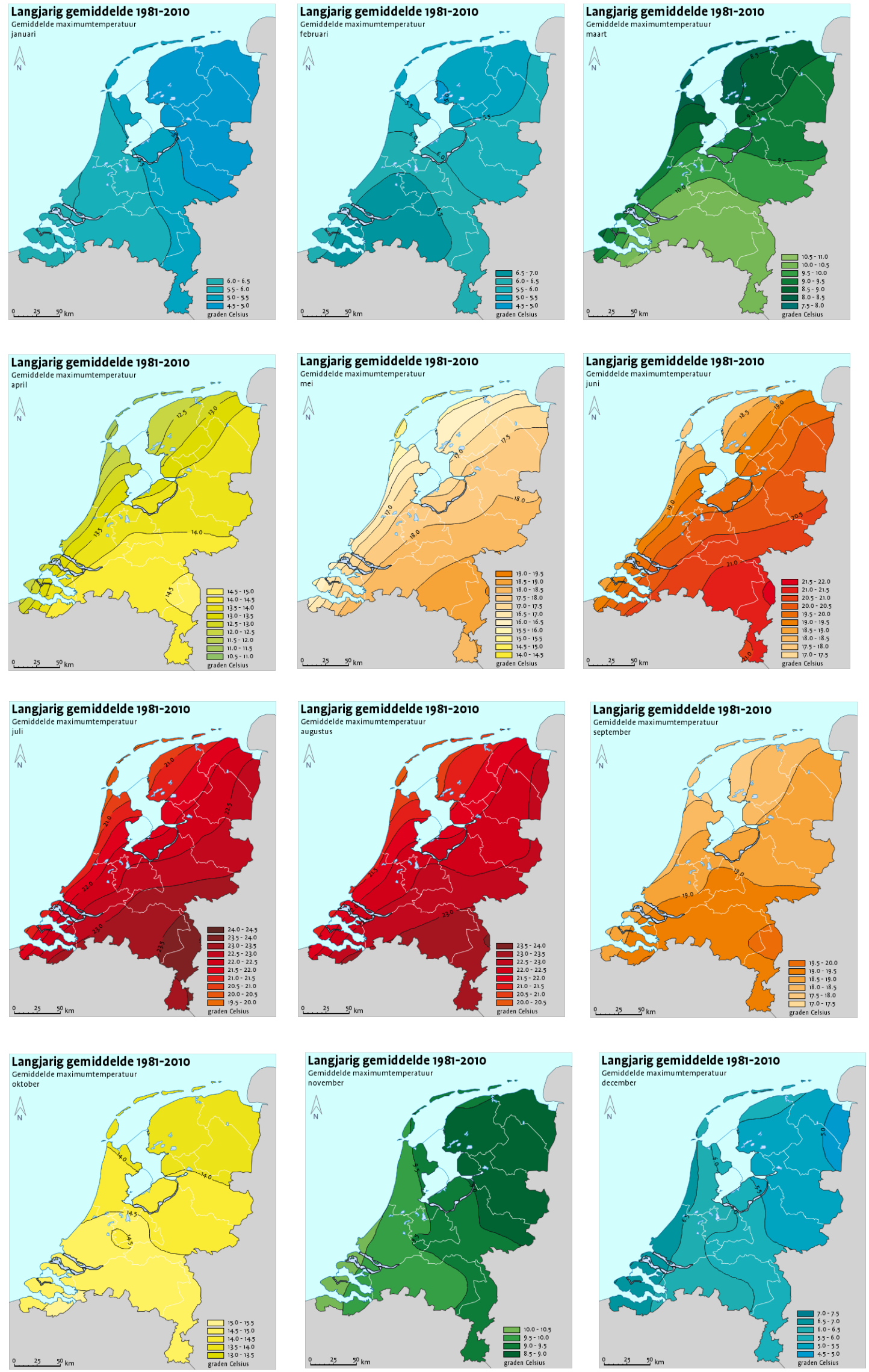

Figuur B Gemiddelde maximumtemperatuur per maand in Nederland. 

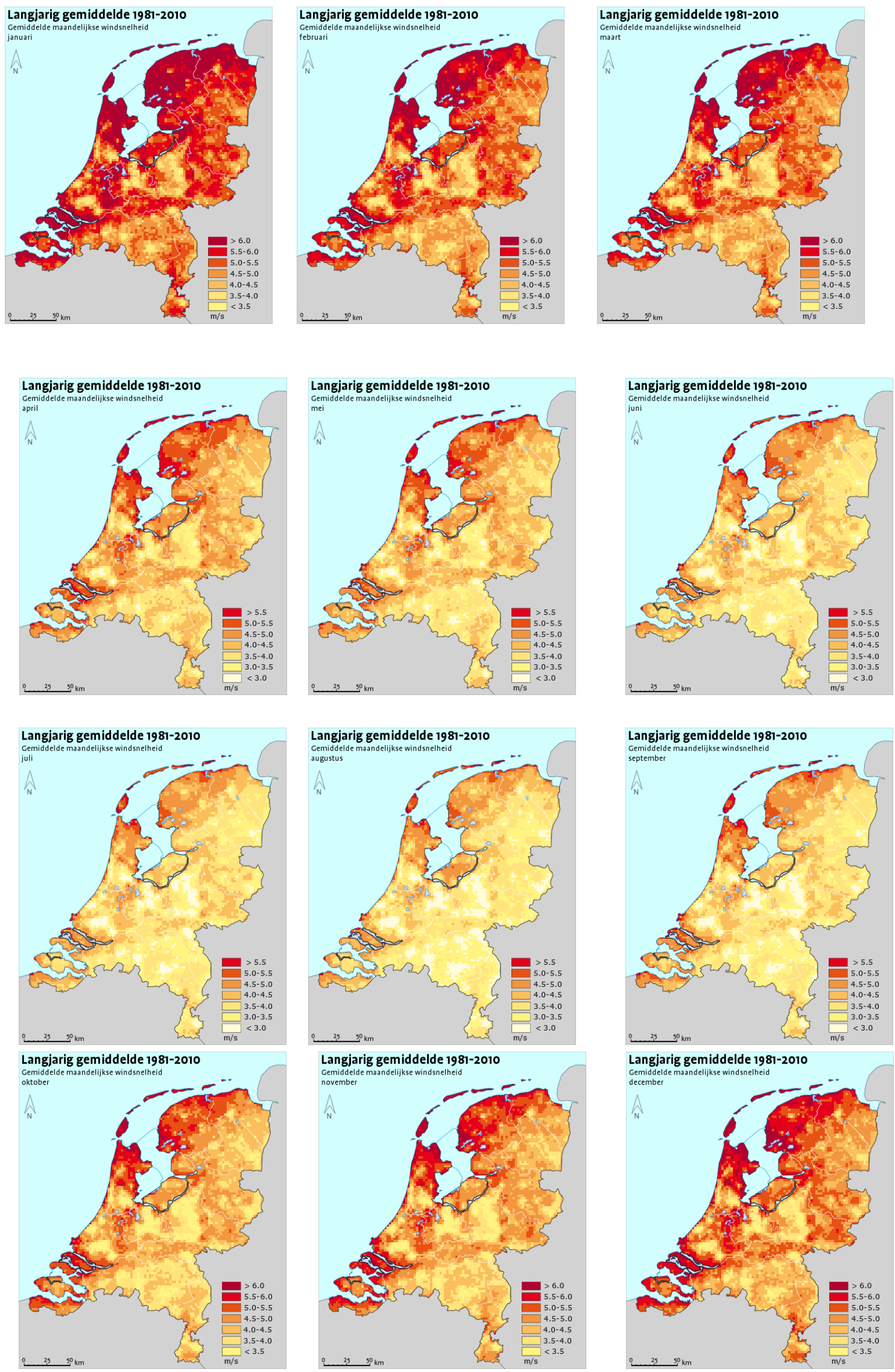

Figur C Gemiddelde windsnelheid per maand in Nederland. 

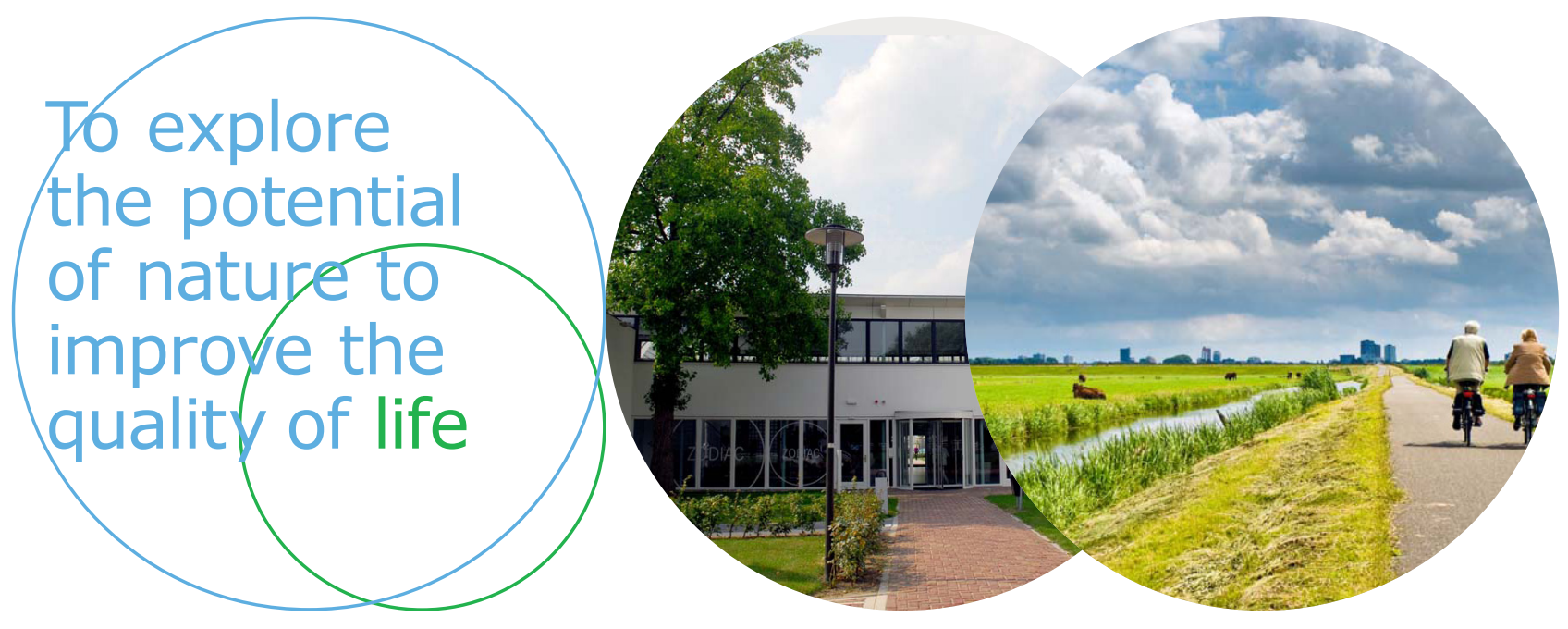

Wageningen Livestock Research Postbus 338

Wageningen Livestock Research ontwikkelt kennis voor een zorgvuldige en $6700 \mathrm{AH}$ Wageningen

T 0317483953

renderende veehouderij, vertaalt deze naar praktijkgerichte oplossingen en innovaties, en zorgt voor doorstroming van deze kennis. Onze wetenschappelijke E info.livestockresearch@wur.nl www.wur.nl/ livestock-research kennis op het gebied van veehouderijsystemen en van voeding, genetica, welzijn en milieu-impact van landbouwhuisdieren integreren we, samen met onze klanten, tot veehouderijconcepten voor de $21 \mathrm{e}$ eeuw.

De missie van Wageningen University \& Research is 'To explore the potential of nature to improve the quality of life'. Binnen Wageningen University \& Research bundelen 9 gespecialiseerde onderzoeksinstituten van Stichting Wageningen Research en Wageningen University hun krachten om bij te dragen aan de oplossing van belangrijke vragen in het domein van gezonde voeding en leefomgeving. Met ongeveer 30 vestigingen, 6.500 medewerkers en 10.000 studenten behoort Wageningen University \& Research wereldwijd tot de aansprekende kennisinstellingen binnen haar domein. De integrale benadering van de vraagstukken en de samenwerking tussen verschillende disciplines vormen het hart van de unieke Wageningen aanpak. 